INSTITUTO DE PESQUISAS ENERGÉTICAS E NUCLEARES

Autarquia associada à Universidade de São Paulo

\title{
ESTUDO COMPARATIVO DAS TENSÕES CISALHANTES \\ NA INTERFACE ENTRE CAMADAS \\ DE UM COMPÓSITO POLIMÉRICO DE FIBRA DE CARBONO \\ PELOS MÉTODOS NUMÉRICO E EXPERIMENTAL
}

\author{
Kira Fukushima Beim \\ Dissertação apresentada como parte \\ dos requisitos para obtenção do \\ Grau de Mestre em Ciências na Área \\ de Tecnologia Nuclear - Materiais. \\ Orientador: \\ Dr. Arnaldo H. P. Andrade
}

SÃO PAULO 


\section{DEDICATÓRIA}

Aos meus pais, Setuko e André por

iluminarem meu caminho e me darem

todo o apoio que precisei

para alcançar meus objetivos

e realizar meus sonhos. 


\section{AGRADECIMENTOS}

Ao IPEN pela oportunidade de desenvolver esta dissertação de mestrado.

Ao Prof. Dr. Arnaldo Homobono Andrade pela sua dedicação, incentivo e paciência ao orientar-me neste trabalho. Minha admiração e agradecimento especial.

Ao Prof. Gerson Marinucci pelo auxilio e dedicação na parte experimental deste trabalho.

A minha família pela compreensão e apoio durante os anos de dedicação ao mestrado. 


\title{
ESTUDO COMPARATIVO DAS TENSÕES CISALHANTES \\ NA INTERFACE ENTRE CAMADAS \\ DE UM COMPÓSITO POLIMÉRICO DE FIBRA DE CARBONO \\ PELOS MÉTODOS NUMÉRICO E EXPERIMENTAL
}

\author{
Kira Fukushima Beim
}

\begin{abstract}
RESUMO
Esse trabalho apresenta a validação do método numérico dos elementos finitos para estimar a resistência ao cisalhamento da interface entre camadas de um compósito polimérico de fibra de carbono. Foram realizados ensaios de Resistência ao Cisalhamento Interlaminar (ILSS, interlaminar shear strength) para validação do modelamento numérico. O método numérico consistiu no desenvolvimento de dois modelos em elementos finitos utilizando um programa comercial (ANSYS Rev. 10). O primeiro usando elementos finitos de casca tridimensional e o segundo, usando elementos finitos planos para simular o ensaio ILSS. O modelo numérico que apresentou resultados mais próximos aos experimentais, o modelo tridimensional de casca, apresentou um erro de apenas $5,6 \%$, indicando uma aproximação bastante satisfatória.
\end{abstract}




\title{
COMPARATIVE STUDY OF THE INTERLAMINAR SHEAR STRESS \\ IN A CARBON FIBER REINFORCED POLYMERIC COMPOSITE USING NUMERICAL AND EXPERIMENTAL METHODS
}

\author{
Kira Fukushima Beim
}

\begin{abstract}
This work presents the validation of the numerical method of finite elements to estimate the interlaminar shear strength in a carbon fiber reinforced polymeric composite. ILSS (interlaminar shear strength) tests were performed to validate the numerical modeling. The numerical method consisted of two different finite element models using a commercial software (ANSYS Rev. 10.0). The first model uses tridimensional shell finite elements and the second model, plane finite elements to simulate the ILSS test. The numerical method that presented the closest results to those from the experimental method was the tridimensional shell model, with an error deviation of only $5.6 \%$, which indicates very good precision.
\end{abstract}




\section{SUMÁRIO}

1 INTRODUÇÃO _

2 OBJETIVO _ 4

3 REVISÃO BIBLIOGRÁFICA___ 5

3.1 Materiais Compósitos___ 5

3.2 Classificação dos Materiais Compósitos __ 7

3.3 Processos de Fabricação___ 10

3.4 Definição das Propriedades dos Materiais Compósitos __ 13

3.5 Laminados 14

3.6 Estados de Tensão em um Material Compósito __ 16

3.7 Mecanismos de Falha em um Material Compósito __ 18

3.8 Critérios de Falha de Materiais Compósitos e Laminados _ 20

3.9 Algumas Considerações sobre o Cisalhamento Interlaminar __ 25

3.10 A Avaliação Experimental das Propriedades da Região Interlaminar de um Compósito

4 MÉTODO EXPERIMENTAL 26

4.1 Aparato e condições de teste___ 30

4.2 Corpo-de-prova _ 33

4.3 Procedimento _ 34

4.4 Resultados do teste _ 34

5 MÉTODO NUMÉRICO _ 36

5.1 Breve Histórico __ 36

5.2 Metodologia _ 37

5.3 Aplicações do Método __ 40

5.4 Nomenclatura _ 40

5.5 Formulação Matemática___ 41

5.6 Propriedades dos Materiais __ 45

5.7 Modelo Plano _ 45

5.8 Resultados para o Modelo Plano__ 55

5.9 Modelo Tridimensional (Layered Shell Element)___ 69

5.10 Resultados para o Modelo Tridimensional___ 77

6 DISCUSSÃO DOS RESULTADOS E CONCLUSÕES___ 80

7 REFERÊNCIAS BIBLIOGRÁFICAS___ 82 


\section{ÍNDICE DE FIGURAS}

Figura 1: Típica falha interlaminar em um corpo-de-prova

Figura 2: Modos I, II e III de falha. 2

Figura 3: (a) Ensaio ILSS de 3 pontos e; (b) ensaio ILSS de 4 pontos. 3

Figura 4: Componentes e equipamentos fabricados com compósito polimérico de fibra de carbono. 6

Figura 5: Arranjo de fibras descontínuas.

Figura 6: Arranjo de fibras contínuas.

Figura 7: Arranjos de fibras versus isotropia do material. ___ 9

Figura 8: Esquema de uma bolsa de vácuo. __ 11

Figura 9: Máquina de bobinagem. __ 12

Figura 10: Peças fabricadas por pultrusão ___ 12

Figura 11: Esquema de fabricação de uma moldagem por transferência de resina 13

Figura 12: Estado plano de tensões no plano xy.___ 16

Figura 13: Micromecanismos de falha. __ 19

Figura 14: Corpo-de-prova sanduíche para ensaio ILSS. __ 27

Figura 15: Dispositivo típico de ensaio ILSS. __ 30

Figura 16: Ensaio ILSS de 3 pontos. __ 31

Figura 17: Corpo-de-prova plano para ILSS. ___ 33

Figura 18: Exemplo de curva carga $x$ deslocamento fornecida pelo teste ILSS._34

Figura 19: Exemplo de modelo e malha de elementos finitos. ___ 38

Figura 20: Modelo de elementos finitos. _ 40

Figura 21: Graus de liberdade de um nó. ___ 41

Figura 22: Analogia Mola/ Barra. __ 42

Figura 23: Sistema com duas molas ___ 43

Figura 24: Elemento finito plano PLANE183 _ 46

Figura 25: Elemento finito de contato TARGE169 __ 47

Figura 26: Elemento finito de contato CONTA172 _ 48

Figura 27: Modelo plano ___ 49

Figura 28: Plotagem para melhor visualização das camadas de epóxi puro e das camadas de fibra de carbono + epóxi__ 50

Figura 29: Malha de elementos finitos __ 52 
Figura 30: Malha de elementos finitos na região do suporte 53

Figura 31: Malha refinada na região do contato 54

Figura 32: (a)Sistema de coordenadas do laminado; (b) Seção transversal do laminado e; (c) Diagrama de corpo livre do laminado 56

Figura 33: Deslocamentos em y 57

Figura 34: Caminhos das linearizações de tensões 59

Figura 35: Distribuição da tensão de cisalhamento, em MPa 60

Figura 36: Distribuição da tensão de cisalhamento nas 15 camadas centrais, 61

Figura 37: Tensões de cisalhamento nos elementos finitos compostos de fibra de carbono + matriz, em MPa (apenas as 15 camadas centrais do corpo-de-prova) 62 Figura 38: Tensões de cisalhamento nos elementos finitos compostos de matriz pura, em MPa (apenas as 15 camadas centrais do corpo-de-prova) 63

Figura 39: tensões cisalhantes na seção "LONGMID" 64

Figura 40: corpo-de-prova após falha por ILSS (foto macro) 65

Figura 41: corpo-de-prova após falha por ILSS (aumento 40x) 66

Figura 42: tensões cisalhantes na seção "TRANSV1" 66

Figura 43: tensões cisalhantes na seção "TRANSV2" 67

Figura 44: tensões cisalhantes na seção "BORDA" 68

Figura 45: Elemento finito de casca multicamadas SHELL99 70

Figura 46: Elemento finito sólido tridimensional SOLID45 71

Figura 47: elemento finito de contato CONTA175 72

Figura 48: Modelo de casca 75

Figura 49: Modelo de elementos finitos (vista frontal) 76

Figura 50: Elementos finitos do corpo-de-prova 76

Figura 51: Distribuição das tensões cisalhantes xz em todo corpo-de-prova (MPa)

Figura 52: Gráfico tensão cisalhante x espessura 78

Figura 53: Tensões cisalhantes na camada 2. Não há variação das tensões através da largura. 


\section{INTRODUÇÃO}

O material do presente estudo é um compósito formado por camadas unidirecionais de fibra de carbono e matriz polimérica, cujas propriedades, tais como elevado módulo de elasticidade, baixa densidade, elevada resistência à fadiga, elevada resistência à ruptura por fluência, elevada resistência à corrosão e baixo coeficiente térmico de dilatação (CDT), são atrativas para aplicações que requerem essas características. É um material bastante usado na indústria química, naval, nuclear, aeronáutica e aeroespacial.

A interface entre camadas, ou região interlaminar de um compósito multicamadas de matriz polimérica é uma fina região de material polimérico (epóxi, poliéster insaturado ou outros) que se encontra entre duas camadas do compósito reforçado (com vidro, carbono, aramida ou outro). É uma região bastante importante para o desempenho desses materiais por garantir, ou não, uma boa adesão entre as camadas que constituem o compósito. A presença de uma falha nessa região pode causar um fenômeno extremamente danoso ao material que é a delaminação. Isso significa que, se na região interlaminar ocorrer uma trinca e esta se propagar, pode haver um descolamento entre camadas e conseqüentemente, falha do material, conforme mostrado na Figura 1.

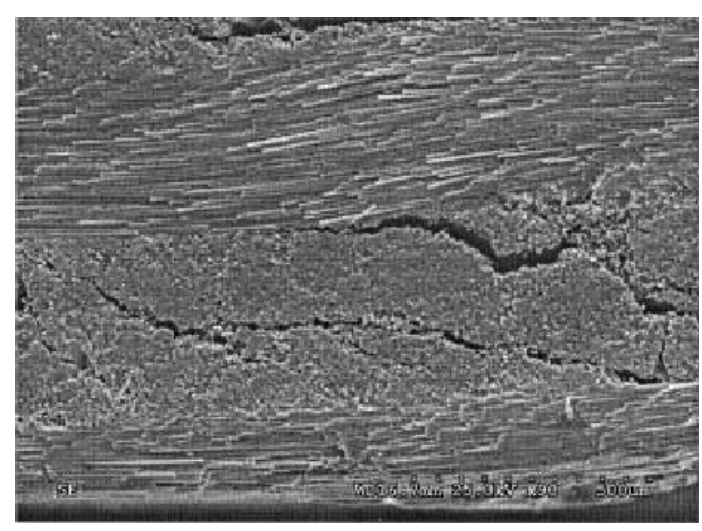

Figura 1: Típica falha interlaminar em um corpo-de-prova do tipo viga curta (micrografia óptica)

Existem três diferentes tipos de carregamento causadores de uma falha. $\mathrm{O}$ modo I é aquele em que a carga principal é aplicada normalmente à falha, 
tendendo a abri-la. O modo II corresponde a um carregamento cisalhante no plano e causa um "escorregamento" entre as superfícies da falha em direções opostas. O modo III refere-se a um cisalhamento fora do plano. A estrutura pode estar sujeita a qualquer um desses modos de carregamento, ou uma combinação de dois ou três desses modos. A Figura 2 ilustra esses modos de carregamento de falha: (ALVES, 2002)

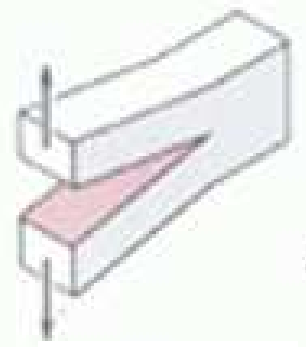

Modo I

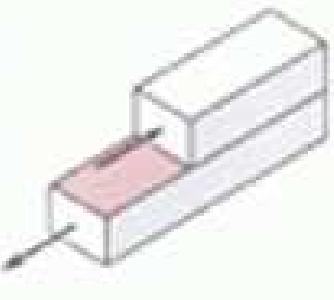

Modo II

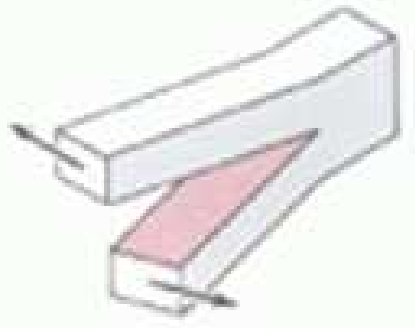

Modo III

Figura 2: Modos I, II e III de falha.

Quando estruturas fabricadas de materiais compósitos estão sujeitas a um carregamento do modo II, a camada interlaminar é a primeira a falhar. Esta falha pode ocorrer devido às tensões de cisalhamento como também por tensões transversais que surgem na região interlaminar, quando o material está sob flexão.

Portanto, a resistência ao cisalhamento da camada interlaminar de um material compósito é de extrema importância, pois pode determinar a resistência à falha do componente, mesmo que o compósito utilize fibras de ótimas propriedades mecânicas, como a fibra de carbono.

Uma maneira de obter a tensão de cisalhamento na região interlaminar de um compósito é fazer o ensaio chamado de Resistência ao Cisalhamento Interlaminar ou ILSS (interlaminar shear strength). Esse ensaio é feito com um carregamento em 3 ou 4 pontos (Figura 3) e aplica uma carga transversal em um corpo-de-prova do tipo viga bastante curto para que não ocorra flexão do corpode-prova, o que causa tensões de cisalhamento na região interlaminar e conseqüente falha do material devido ao descolamento das camadas (ASTM 
D2344/D2344M, 2000). Os valores das tensões de cisalhamento até a falha total do material são registrados em forma de gráfico pelo dispositivo de ensaio. Esse ensaio também é chamado de SBS ("short beam shear") devido ao reduzido comprimento do corpo-de-prova. Os procedimentos do teste devem seguir a norma ASTM D2344/ D2344M.

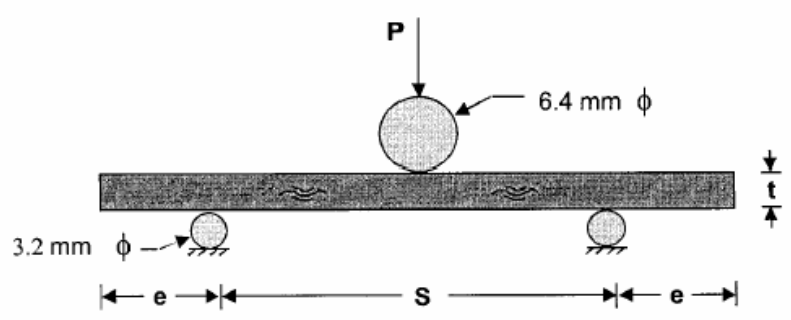

(a)

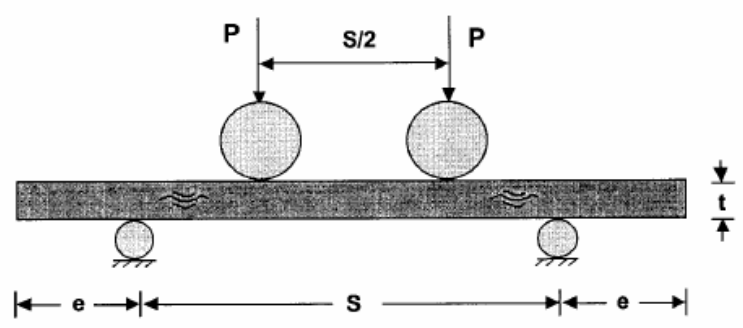

(b)

Figura 3: (a) Ensaio ILSS de 3 pontos e; (b) ensaio ILSS de 4 pontos.

Outra maneira de avaliar a tensão de cisalhamento da região interlaminar de um compósito em que houve falha é pelo método numérico de análise de tensões por elementos finitos. 


\section{OBJETIVO}

O objetivo da presente dissertação é validar o método numérico dos elementos finitos para estimar a resistência ao cisalhamento da interface entre camadas de um compósito polimérico de fibra de carbono a partir de um teste de resistência ao cisalhamento interlaminar (ILSS).

O ensaio experimental para determinação das tensões cisalhantes entre camadas foi análogo aquele de flexão em 3 pontos. O ensaio será descrito em detalhes mais adiante. Em paralelo, foi feito um estudo pelo método numérico.

O método numérico consiste em duas diferentes formas de modelagem por elementos finitos com o programa ANSYS Rev. 10.0 para avaliar qual delas melhor representa a realidade do teste ILSS. 


\section{REVISÃO BIBLIOGRÁFICA}

\subsection{Materiais Compósitos}

Um material compósito estrutural é um material que consiste de duas ou mais fases numa escala macroscópica, no qual as propriedades mecânicas são projetadas para serem otimizadas para uma determinada aplicação, diferentes daquelas de cada fase (material) agindo independentemente. Uma das fases é usualmente mais rígida e mais resistente, chamada de reforço, enquanto a outra fase, menos resistente, é continua e chamada matriz. Às vezes, devido às interações químicas ou outros efeitos de processo, uma fase adicional, chamada interfase, existe entre o reforço e a matriz.

As propriedades de um material compósito dependem das propriedades de seus constituintes, geometria e distribuição das fases. Um dos parâmetros mais importantes é a fração volumétrica ou fração de peso de reforço (fibra). A distribuição da fibra determina a homogeneidade ou uniformidade do material compósito. Quanto mais uniforme a distribuição do reforço, mais homogêneo é o material e menor a probabilidade de falha nas áreas mais frágeis. A geometria e orientação da fibra afetam a anisotropia do sistema. (DANIEL \& ISHAI, 1994)

Historicamente, os materiais compósitos poliméricos são relativamente recentes. Resina fenólica reforçada com fibras de asbestos foi introduzida no início do século 20. O primeiro barco feito de fibra de vidro foi construído em 1942. Plásticos reforçados eram usados também em aviões e componentes eletrônicos naquela época. "Filament Winding", um método de fabricação de compósitos através do enrolamento de fio contínuo, foi inventado em 1946 e utilizado na fabricação de mísseis nos anos 1950. As primeiras fibras de carbono de alta resistência foram introduzidas no início dos anos 1960, com aplicações na área aeronáutica. Em 1973 a Dupont desenvolveu a fibra aramida e atribuiu ao material o nome de Kevlar. A partir do final dos anos 1970, a aplicação de materiais compósitos se expandiu largamente para as áreas aeronáutica, automotiva, esportiva e indústrias químicas. (DANIEL \& ISHAI, 1994) 
O compósito polimérico de fibra de carbono, material de estudo, é constituído de matriz polimérica de epóxi e fibra de carbono como reforço. É uma material tipicamente conhecido por apresentar ótimas propriedades mecânicas, tais como: elevado módulo de elasticidade, baixa densidade, elevada resistência à fadiga, elevada resistência à corrosão e baixo coeficiente térmico de dilatação (CDT). Estas propriedades tornam $\mathrm{o}$ material composto de fibra de carbono extremamente atraente para as mais diversas aplicações: indústria química, naval, nuclear, aeronáutica, aeroespacial, esportiva entre outras. A Figura 4 ilustra alguns componentes e equipamentos fabricados em material compósito polimérico de fibra de carbono.

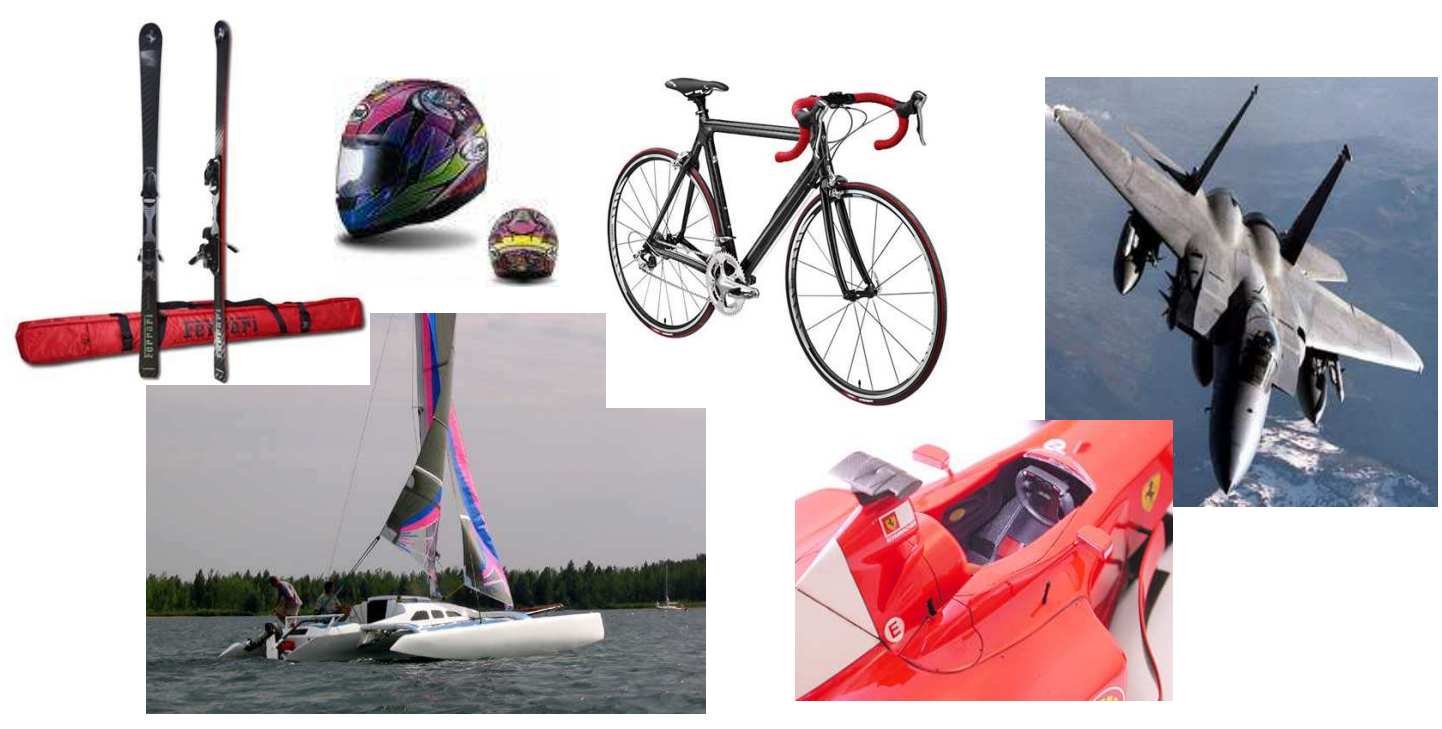

Figura 4: Componentes e equipamentos fabricados com compósito polimérico de fibra de carbono.

Quando visto apenas numa escala de dimensão das fibras, materiais compósitos têm a vantagem da alta rigidez e alta resistência das fibras. A baixa tenacidade à fratura da fibra é compensada pela energia dissipada na interface fibra/ matriz e a ductilidade da matriz. Justamente por este motivo, a adesão entre a fibra e a matriz deve ser alta suficiente para transferir essa energia entre os componentes do material compósito. 
O nível de adesão entre a fibra e a matriz, ou "bonding", é um importante assunto de estudo. Esta interface é também conhecida por região intralaminar, diferente da região interlaminar, objeto do presente estudo. A região interlaminar, por sua vez, corresponde a uma fina camada de matriz entre duas camadas de compósito (fibra+matriz). É também uma região muito importante a ser estudada por apresentar menor resistência mecânica que as camadas vizinhas e ser, conseqüentemente, constante motivo de falha do material devido aos deslocamentos entre camadas. (DANIEL \& ISHAI, 1994)

\subsection{Classificação dos Materiais Compósitos}

Os materiais compósitos podem ser classificados conforme o tipo de reforço e conforme o tipo de matriz. O reforço, geometricamente, pode estar na forma de particulado, fibra contínua e fibra descontínua. (ALMEIDA, 2005)

Um compósito particulado consiste de partículas de várias formas e tamanhos dispersas aleatoriamente na matriz. Os compósitos particulados podem ser considerados quase-homogêneos numa escala bem maior do que o tamanho médio das partículas. Devido à aleatoriedade da distribuição das partículas os compósitos particulados podem ser considerados quase-isotrópicos. Alguns exemplos de compósito particulado: concreto, partículas de alumínio em poliuretano (usado em propelentes de foguetes), partículas de carbeto de silício em alumínio. (ALMEIDA, 2005)

Um compósito com fibras descontínuas pode conter fibras curtas ou whiskers como reforço. A razão de aspecto entre o comprimento e o diâmetro das fibras é alta e a orientação das fibras pode ser aleatória ou unidirecional. Sua utilização é, em geral, em aplicações de baixa solicitação mecânica. A Figura 5 ilustra as fibras descontínuas aleatórias e unidirecionais: (ALMEIDA, 2005) 


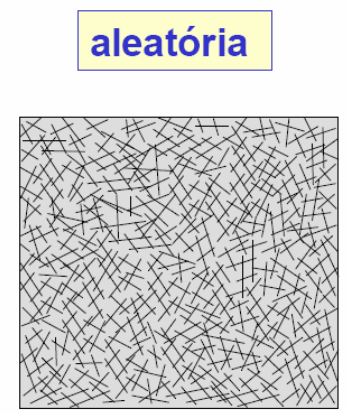

\section{unidirecional}

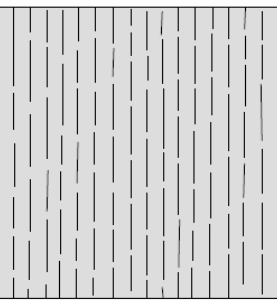

Figura 5: Arranjo de fibras descontínuas.

Devido à aleatoriedade da distribuição das fibras, os compósitos com fibras descontínuas com orientação aleatória podem ser considerados quasi-isotrópicos. O material pode ser encontrado na forma de mantas de fibras picadas.

(ALMEIDA, 2005)

Um compósito com fibras contínuas contém fibras longas e contínuas. A orientação das fibras pode ser unidirecional, bi-direcional ou multidirecional. Fibras contínuas são utilizadas em aplicações nas quais se requer alta rigidez e resistência. A Figura 6 ilustra os diferentes arranjos de fibras contínuas: (ALMEIDA, 2005)

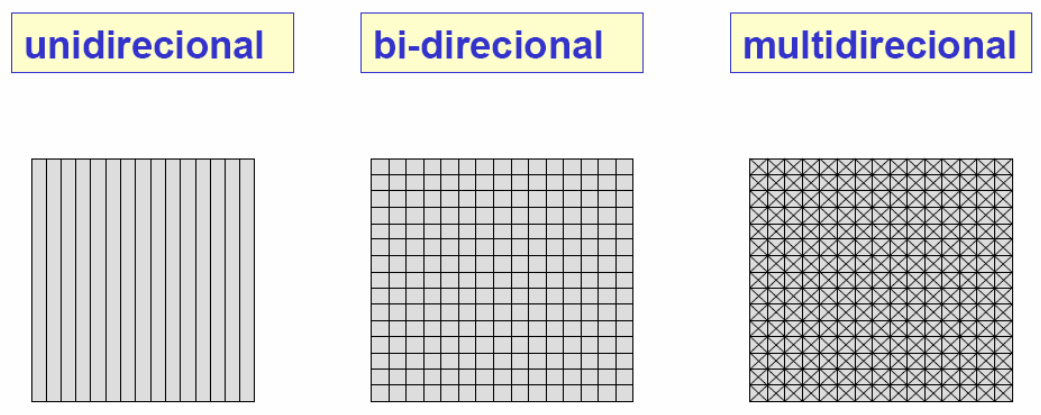

Figura 6: Arranjo de fibras contínuas.

O esquema da Figura 7 mostra os diferentes arranjos de fibras e sua relação com a isotropia do material: (ALMEIDA, 2005) 


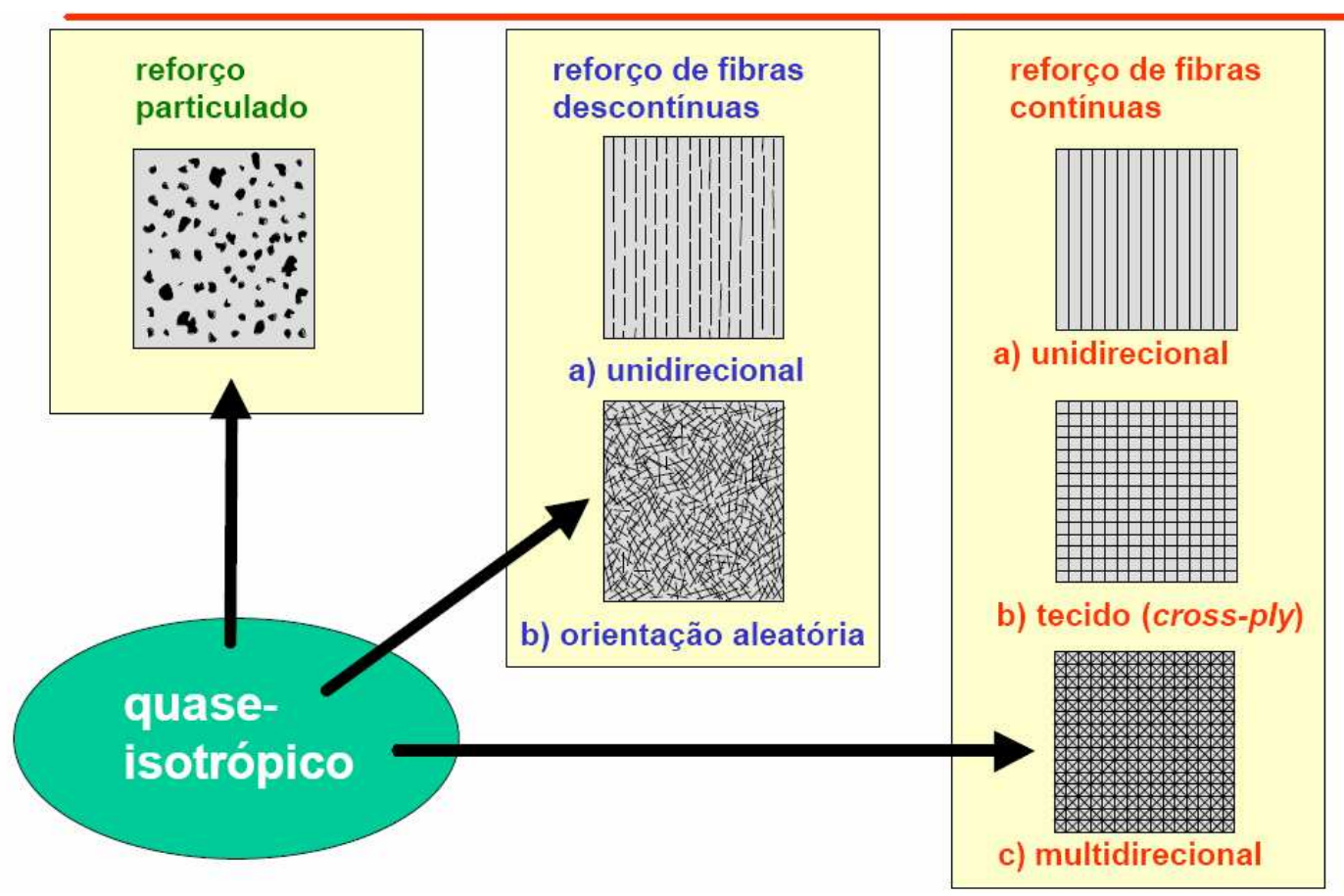

Figura 7: Arranjos de fibras versus isotropia do material.

Quanto à composição da matriz, esta pode ser: polimérica, cerâmica, metálica ou carbono. (ALMEIDA, 2005)

A matriz polimérica divide-se em termoplástica e termorrígida (ou termofixa). É aplicada para compósitos reforçados por fibra de vidro, aramida ou carbono e em aplicações de temperaturas relativamente baixas. A matriz polimérica tem as seguintes vantagens: fácil processamento, custo de fabricação relativamente baixo e flexibilidade na orientação das fibras. (ALMEIDA, 2005)

A matriz polimérica termoplástica apresenta as seguintes características: alta tenacidade e ductilidade, consolidação (transformação física), processamento difícil e temperatura de uso limitada pela temperatura de amolecimento ou fusão. (ALMEIDA, 2005)

A matriz polimérica termorrígida apresenta as seguintes características: passa pelo processo da cura (transformação química), uma vez curada não pode ser refundida, é resistente, rígida, frágil, perecível, de processamento simples e temperatura de uso relativamente baixa. (ALMEIDA, 2005) 
Matrizes cerâmicas são utilizadas para aplicações que requerem uso contínuo sob temperaturas muito elevadas. Apresentam as seguintes características: alta temperatura de uso, baixa densidade, alta rigidez e dureza, processamento complexo, isolamento elétrico, frágil (baixa tenacidade à fratura) e baixa tolerância ao dano. (ALMEIDA, 2005)

Matrizes metálicas são utilizadas para aplicações que requerem uso contínuo sob temperaturas elevadas e propriedades mecânicas elevadas. Apresentam as seguintes características: alta temperatura de uso, alta rigidez e resistência, alta condutividade térmica, alta tenacidade à fratura e alta tolerância ao dano. (ALMEIDA, 2005)

Matrizes de carbono são sempre reforçadas por fibras de carbono, formando um compósito carbono-carbono. Essas matrizes são utilizadas para aplicações que requerem alta resistência a temperaturas muito elevadas (exemplos: tubeira de foguete, freios de aviões). Apresentam as seguintes características: alta temperatura de uso, alta rigidez, baixa densidade, baixa expansão térmica, boa condutividade térmica e elétrica e processamento difícil. (ALMEIDA, 2005)

\subsection{Processos de Fabricação}

O processo de fabricação é uma parte bastante importante na aplicação dos materiais compósitos. Uma grande variedade de métodos de fabricação se adapta às varias aplicações disponíveis. Eles incluem moldagem por bolsa de vácuo, bobinagem, pultrusão e moldagem por transferência de resina (RTM). (ALMEIDA, 2005)

Componentes fabricados por autoclave ou bolsa de vácuo caracterizam-se por baixo conteúdo de vazios (cura sob pressão) e alto volume de fibras. É um método de fabricação indicado para peças de espessura fina e forma complexa e estruturas sanduíche. A fabricação por bolsa de vácuo tem as seguintes vantagens: resulta em peças de baixa porosidade, permite rígido controle 
fibra/resina, usa ferramental simples e permite variados ciclos de cura. Dentre as desvantagens deste método, tem-se: alto custo da matéria prima (reforço préimpregnado), excesso de sobras de material, exige sala de laminação climatizada, o reforço pré-impregnado é perecível, exige elevado consumo de energia e o produto final apresenta apenas uma única superfície acabada. A Figura 8 ilustra o esquema de fabricação de uma bolsa de vácuo: (ALMEIDA, 2005)

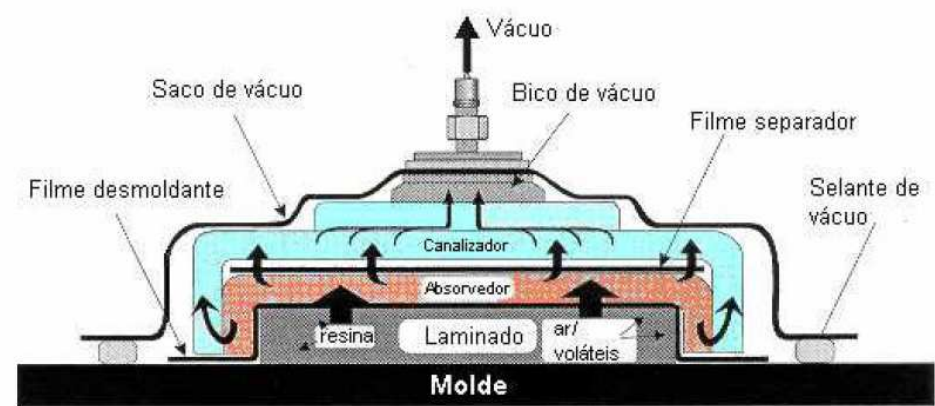

Figura 8: Esquema de uma bolsa de vácuo.

A bobinagem é um método de fabricação indicado para peças axisimétricas como vasos de pressão, tanques e dutos. É um método que se caracteriza por baixo conteúdo de vazios, bom controle do posicionamento da fibra e bom aproveitamento do material. A bobinagem apresenta as seguintes vantagens: possibilita fabricação de peças grandes e pequenas, permite bom controle da posição da fibra, permite excelente aproveitamento do material e permite uso de liners em vasos de pressão. Dentre as desvantagens do processo, tem-se: limitado a formas axisimétricas, mau controle do conteúdo de resina e exige controle operacional (programação, parâmetros do processo). A Figura 9 ilustra uma máquina de bobinagem. (ALMEIDA, 2005) 


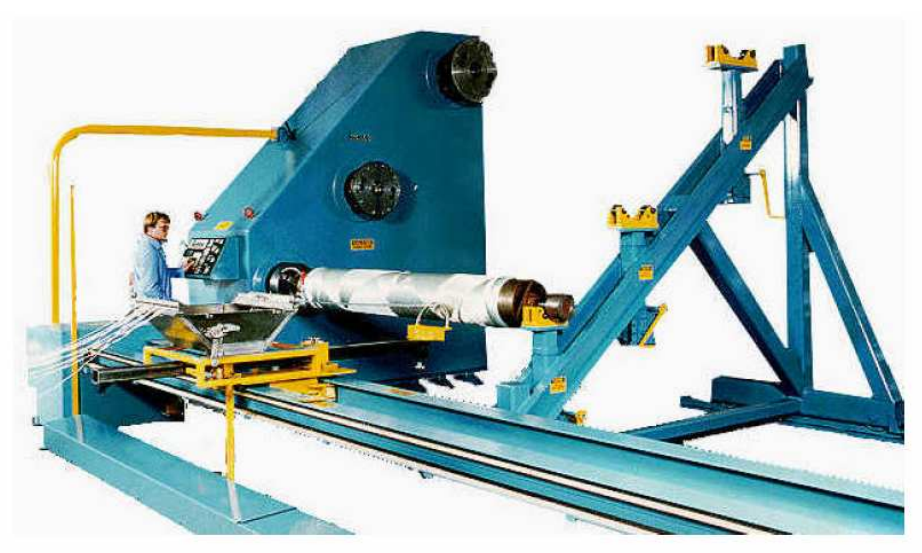

Figura 9: Máquina de bobinagem.

A pultrusão é um método que se caracteriza por: processo contínuo, baixo conteúdo de vazios, alto volume de fibras e bom aproveitamento do material. É um método aplicado para peças com seção transversal constante (sólidas ou vazadas). A pultrusão apresenta as seguintes vantagens: excelente aproveitamento do material, alta taxa de produção, alto conteúdo de resina ou de fibra. Dentre as desvantagens do processo, tem-se: seção transversal tem que ser uniforme, a cura rápida pode reduzir propriedades e baixa resistência transversal. A Figura 10 ilustra componentes típicos fabricados por pultrusão. (ALMEIDA, 2005)

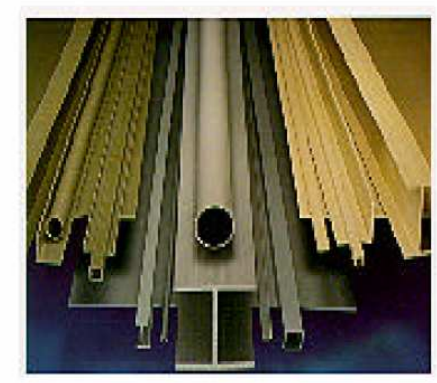

Figura 10: Peças fabricadas por pultrusão

A moldagem por transferência de resina (RTM) é um método que se caracteriza por utilizar pré-forma impregnada em molde fechado, alta cadência de produção, bom aproveitamento do material e acabamento nas duas superfícies. É um método aplicado para fabricação de peças com grandes lotes e geometrias complexas. A moldagem por transferência de resina apresenta as seguintes vantagens: excelente aproveitamento do material, alta taxa de produção, bom 
acabamento nas duas superfícies, permite moldagem de formas complexas e permite fabricação de peças grandes e pequenas. Dentre as desvantagens do processo, tem-se custo do molde, que é viável somente para lotes grandes. A Figura 10 ilustra o esquema de fabricação de uma moldagem por transferência de resina: (ALMEIDA, 2005)

MOLDAGEM
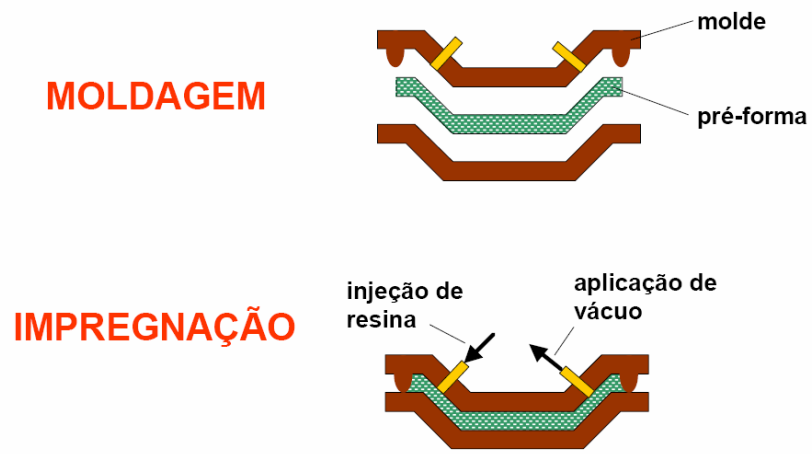

Figura 11: Esquema de fabricação de uma moldagem por transferência de resina.

Componentes estruturais que consistem de diferentes materiais, como estruturas tipo sanduíche de honeycomb (colméia), podem ser fabricados pelo processo chamado de cura conjunta, método em que elementos diferentes são curados ao mesmo tempo, obedecendo a um mesmo ciclo de cura. No entanto, a fabricação do material compósito ainda depende de mão de obra qualificada, com certa limitação quanto à automação ou padronização. Isso requer um controle de qualidade mais extenso e rígido. (DANIEL \& ISHAI, 1994)

\subsection{Definição das Propriedades dos Materiais Compósitos}

Um material é homogêneo se suas propriedades são as mesmas em todos os pontos ou são independentes da localização. O conceito de homogeneidade está associado com uma escala ou volume característico e pela definição de propriedades envolvidas. Dependendo da escala ou volume observado, o material pode ser mais ou menos homogêneo. Se existe baixa variabilidade das propriedades de ponto a outro, numa escala macroscópica, o material é referenciado como quase homogêneo. (DANIEL \& ISHAI, 1994) 
Muitas propriedades do material, como rigidez, resistência mecânica, expansão térmica e condutividade térmica, são associadas com a direção ou eixo. O material é considerado isotrópico quando suas propriedades são as mesmas em todas as direções, independentemente da orientação do eixo de referência. (DANIEL \& ISHAI, 1994)

Um material é anisotrópico quando suas propriedades em um ponto variam com a direção ou dependem da orientação dos eixos de referência. Se as propriedades do material ao longo de qualquer direção são aquelas ao longo de uma direção simétrica em relação a um plano, então, este plano é definido como plano de simetria do material. Um material pode ter nenhum, um, dois, três, ou infinito número de planos de simetria do material através de um ponto. Um material isotrópico tem um número infinito de planos de simetria. (DANIEL \& ISHAI, 1994)

Materiais compósitos, em especial, são materiais ortotrópicos, isto é, são materiais de três planos de simetria perpendiculares entre si. As intersecções destes planos definem três eixos perpendiculares entre si, chamados de eixos principais de simetria do material, ou simplesmente, eixos principais do material. (DANIEL \& ISHAI, 1994)

\subsection{Laminados}

Uma lâmina é uma camada plana (ou curva) de fibras unidirecionais ou tecido em uma matriz. No caso de fibras unidirecionais, tem-se uma lâmina unidirecional. A lâmina é um material ortotrópico com eixos principais do material na direção longitudinal (direção das fibras), direção transversal (normal às fibras no plano da lâmina) e normal ao plano da lâmina. (DANIEL \& ISHAI, 1994)

Um laminado é constituído de duas ou mais lâminas unidirecionais empilhadas em várias orientações. Os laminados podem ter várias espessuras ou podem consistir de diferentes materiais. Como os eixos principais dos materiais mudam de camada a camada, é mais conveniente analisar laminados usando um 
sistema fixo e comum de coordenadas. A orientação de uma determinada camada é dada pelo ângulo entre o eixo $x$ de referência e o eixo principal do material (orientação da fibra) da camada, medida no sentido anti-horário no plano x-y. (DANIEL \& ISHAI, 1994)

A denominação dos laminados depende do número, tipo, orientação e seqüência de empilhamento das lâminas. Quando o laminado contém dois ou mais tipos de materiais, é chamado híbrido. A seguir, estão listadas algumas configurações típicas de laminados e exemplos de representação pelas regras de denominação de laminados: (DANIEL \& ISHAI, 1994)

Unidirecional de 6 camadas:

$$
[0 / 0 / 0 / 0 / 0 / 0]=\left[0_{6}\right]
$$

Simétrico com camadas cruzadas (cross-ply) $\left(0\right.$ e $\left.90^{\circ}\right)$ :

$$
[0 / 90 / 90 / 0]=[0 / 90]_{\mathrm{s}}
$$

Simétrico multidirecional (angle-ply):

$$
\begin{aligned}
& {[+45 /-45 /-45 /+45]=[ \pm 45]_{s}} \\
& {[30 /-30 / 30 /-30 /-30 / 30 /-30 / 30]=[ \pm 30]_{2 s}}
\end{aligned}
$$

Assimétrico multidirecional (angle-ply):

$$
[30 /-30 / 30 /-30 / 30 /-30 / 30 /-30]=[ \pm 30]_{4}
$$

Multidirecional (angle ply):

$$
[0 / 45 /-45 /-45 / 45 / 0]=[0 / \pm 45]_{s}
$$

Híbrido:

$$
\left[0^{\mathrm{K}} / 0^{\mathrm{K}} / 45^{\mathrm{C}} /-45^{\mathrm{C}} / 90^{\mathrm{G}} /-45^{\mathrm{C}} / 45^{\mathrm{C}} / 0^{\mathrm{K}} / 0^{\mathrm{K}}\right]_{\mathrm{T}}=\left[0_{2}^{\mathrm{K}} / \pm 45^{\mathrm{C}} / \overline{90}{ }^{\mathrm{G}} /\right]_{\mathrm{S}}
$$

Onde os símbolos significam:

$$
\begin{aligned}
& \text { Número subscrito = número de camadas } \\
& \mathrm{S}=\text { seqüência simétrica } \\
& \mathrm{T}=\text { número total de camadas } \\
& \text { — = barra sobre ângulo da camada denota que o laminado é } \\
& \text { simétrico sobre o plano médio desta camada }
\end{aligned}
$$


Um laminado é considerado balanceado quando o número de camadas de um mesmo material e de uma mesma orientação de fibra é o mesmo, ou seja, como se o plano médio (paralelo à espessura do laminado) fosse um espelho das camadas. (DANIEL \& ISHAI, 1994)

\subsection{Estados de Tensão em um Material Compósito}

$\mathrm{Na}$ Figura 11, as componentes com um único índice $\left(\sigma_{x}, \sigma_{y}\right.$ e $\left.\sigma_{z}\right)$ são chamadas tensões normais (atuam perpendicularmente às faces). As componentes com índices diferentes $\left(\tau_{x y}, \tau_{x z}\right.$ e $\left.\tau_{y z}\right)$ são chamadas tensões de cisalhamento (atuam tangencialmente às faces).

Quando todos os três componentes de tensões fora do plano são iguais a zero através da região, então se tem uma condição de estado plano de tensões. Por exemplo, na Figura 12, a tensão normal $\sigma_{z}$ e ambas componentes de cisalhamento $\tau_{z x}$ e $\tau_{z y}$ fora do plano são nulas para a condição de estado plano de tensões no plano xy. As componentes de tensão não nulos, nesse caso, são $\sigma_{x}$, $\sigma_{y}$ e $\tau_{x y}$. Nota-se que os componentes de deformação não são necessariamente nulas para o estado plano de tensões no plano xy. $O$ estado plano de tensões é típico de placas finas. (HERAKOVICH, 1998)

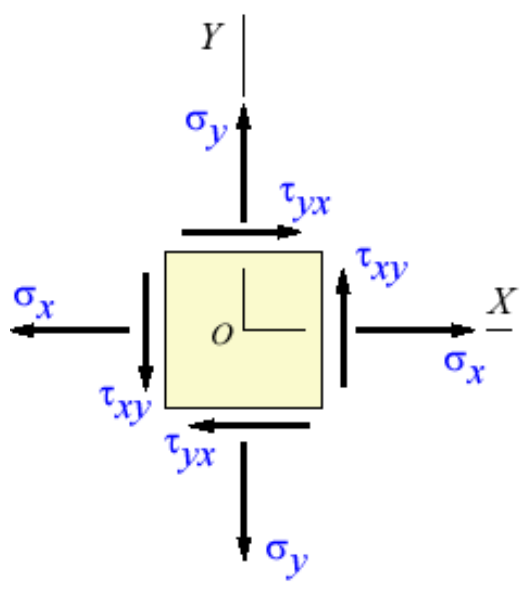

Figura 12: Estado plano de tensões no plano xy. 
A magnitude dos componentes $z$ de deformação depende da equação constitutiva expressa a seguir: (HERAKOVICH, 1998)

$$
\varepsilon_{i j=} S_{i j k l} \sigma_{k l}
$$

onde S é a inversa da matriz de rigidez.

A deformação normal $\varepsilon_{z z}$ fora do plano é não-nula para materiais que tem coeficientes de Poisson não-nulos. Para o caso de estado plano de tensões no plano $x y$, as equações de equilíbrio se reduzem a seguinte forma mais simples: (HERAKOVICH, 1998)

$$
\begin{aligned}
& \frac{\partial \sigma_{x}}{\partial x}+\frac{\partial \tau_{x y}}{\partial y}=0 \\
& \frac{\partial \tau_{x y}}{\partial x}+\frac{\partial \sigma_{y}}{\partial y}=0
\end{aligned}
$$

E as equações de compatibilidade se reduzem à única equação:

$$
2 \varepsilon_{x y, y x}=\varepsilon_{x x, y y}+\varepsilon_{y y, x x}
$$

Já a condição de estado plano de deformação corresponde à situação em que as três componentes de deformação fora do plano $\left(\varepsilon_{\mathrm{zz}}, \varepsilon_{\mathrm{zx}}, \varepsilon_{\mathrm{zy}}\right)$ são nulas e as tensões são, na maioria, funções de x e y. Assim como a condição de estado plano de tensões, as componentes de tensão fora do plano pela forma de equações constitutivas, e a tensão normal $\sigma_{z}$ é geralmente não-nula. Equilíbrio se reduz a: (HERAKOVICH, 1998)

$$
\begin{aligned}
& \frac{\partial \sigma_{x}}{\partial x}+\frac{\partial \tau_{x y}}{\partial y}=0 \\
& \frac{\partial \tau_{x y}}{\partial x}+\frac{\partial \sigma_{y}}{\partial y}=0
\end{aligned}
$$


Com as componentes de deformação fora do plano $\left(\varepsilon_{z z}, \varepsilon_{z x}, \varepsilon_{z y}\right)$ iguais a zero, as equações de compatibilidade se reduzem a uma única equação: (HERAKOVICH, 1998)

$$
2 \varepsilon_{x y, y x}=\varepsilon_{x x, y y}+\varepsilon_{y y, x x}
$$

Logo, nota-se que a equação de compatibilidade é a mesma para estado plano de tensões e estado plano de deformação. (HERAKOVICH, 1998)

\subsection{Mecanismos de Falha em um Material Compósito}

Existem vários micromecanismos de falha de um material compósito, destacando-se a fratura da fibra, flambagem da fibra, arrancamento, descolamento da fibra/ matriz, trincamento da matriz e trincamento radial (ilustrados na Figura 13). No caso de laminados, os mecanismos de falha microscópicos se manifestam nas falhas da lâmina em forma de trincas transversais nos planos paralelos às fibras, falhas da fibra em planos perpendiculares às fibras e delaminação entre camadas do laminado. (DANIEL \& ISHAI, 1994) 


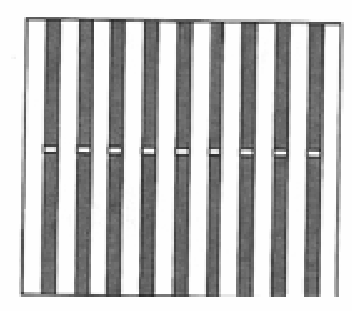

a) Fiatur d tas finas

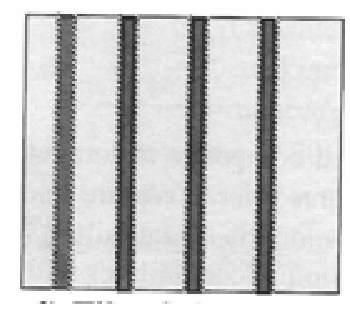

d) Descolamento fitud/'matuis

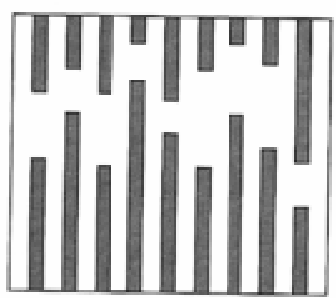

b) Arrancamento

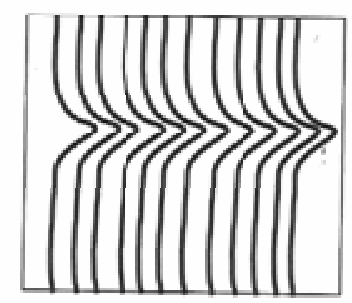

e) Flambagem das fibras

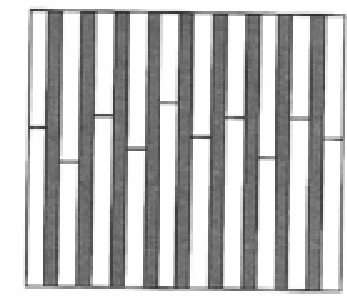

c) Trincamento da matriz

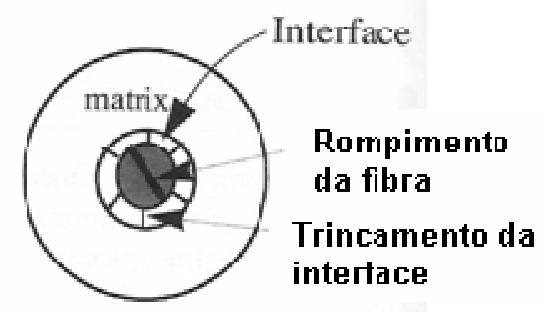

f) Fratura radial da interface e iumpimenu da fitud

Figura 13: Micromecanismos de falha.

Fratura transversal da fibra, ou seja, quebra de uma fibra contínua em dois ou mais segmentos distintos, é o mais catastrófico mecanismo de falha, já que as fibras são tipicamente os principais receptores do carregamento. A fratura da fibra pode resultar também de tensões trativas ou compressivas. A fratura da fibra (Figura 13.a) ocorre sob carregamento de tração quando a tensão de tração axial máxima admissível (ou deformação) da fibra é excedida. Arrancamento (Figura 13.b) ocorre quando a resistência da matriz é excedida. Flambagem da fibra (Figura 13.e) ocorre quando a tensão axial compressiva causa a flambagem da fibra. A tensão crítica de flambagem para uma fibra embebida em matriz é uma função das propriedades da fibra e da matriz (que proporciona suporte lateral para a fibra). Rompimento da fibra e trincamento radial da interface (Figura 13.f) ocorrem quando as tensões transversais ou tangenciais em uma fibra ou região de interface entre fibra e matriz chegam ao valor de sua ruptura. (DANIEL \& ISHAI, 1994) 


\subsection{Critérios de Falha de Materiais Compósitos e Laminados}

Existem vários critérios para determinar a falha de um material compósito. Alguns desses critérios serão explicados a seguir:

Teoria da Máxima Tensão: Uma falha ocorrerá quando algum dos componentes de tensão é igual ou maior que a força intrínseca admissível correspondente. Portanto, a falha ocorreria se: (CHAWLA, 1987)

$$
\begin{array}{ll}
\sigma_{1} \geq X_{1}^{T} & \sigma_{1} \leq-X_{1}^{C} \\
\sigma_{2} \geq X_{2}^{T} & \sigma_{2} \leq-X_{2}^{C} \\
\sigma_{6} \geq S &
\end{array}
$$

Onde:

$\sigma_{1}$ é a tensão aplicada na direção da fibra

$\sigma_{2}$ é a tensão aplicada na direção transversal da fibra

$\sigma_{6}$ é a tensão de cisalhamento no plano

$X_{1}^{T}$ é a resistência de ruptura à tração uniaxial na direção da fibra

$X_{1}^{C}$ é a resistência de ruptura à compressão uniaxial na direção da fibra $X_{2}^{T}$ é a resistência de ruptura à tração uniaxial na direção transversal da fibra

$X_{2}^{C}$ é a resistência de ruptura à compressão uniaxial na direção transversal da fibra

$S$ é a resistência de ruptura ao cisalhamento.

Quando alguma das desigualdades indicadas acima é atingida, o material irá falhar pelo modo de falha relacionado àquela desigualdade de tensão. $\mathrm{O}$ critério da tensão máxima só pode ser aplicado nas direções principais da lâmina e nenhuma interação entre modos de falha é permitida nesse critério. (CHAWLA, 1987) 
Critério da Máxima Deformação: Este critério é análogo ao critério de máxima tensão. Uma falha ocorre quando algum dos componentes de deformação é igual ou maior à sua deformação admissível. Portanto, (CHAWLA, 1987)

$$
\begin{array}{cc}
\varepsilon_{1} \geq e_{1}^{T} & \varepsilon_{1} \leq-e_{1}^{C} \\
\varepsilon_{2} \geq e_{2}^{T} & \varepsilon_{2} \leq-e_{2}^{C} \\
\varepsilon_{6} \geq e^{6} & \varepsilon_{6} \leq e_{6}
\end{array}
$$

Onde:

$\varepsilon_{1}$ é a deformação resultante na direção da fibra

$\varepsilon_{2}$ é a deformação resultante na direção transversal da fibra

$\varepsilon_{6}$ é a deformação resultante cisalhante

$e_{1}^{T}$ é a deformação de ruptura à tração na direção da fibra

$e_{1}^{C}$ é a deformação de ruptura de compressão na direção da fibra

$e_{2}^{T}$ é a deformação de ruptura à tração na direção transversal

$e_{2}^{C}$ é a deformação de ruptura de compressão na direção transversal

$e_{6}$ é a resistência de ruptura ao cisalhamento.

O critério da deformação máxima também só pode ser aplicado nas direções principais da lâmina.

Critério do Máximo Trabalho (Ou Tsai-Hill) De acordo com o critério de Tsai-Hill, uma falha de uma lâmina ortotrópica irá ocorrer sob um estado geral de tensões quando: (CHAWLA, 1987)

$$
\frac{\sigma_{1}^{2}}{X_{1}^{2}}-\frac{\sigma_{1} \sigma_{2}}{X_{1}^{2}}+\frac{\sigma_{2}^{2}}{X_{2}^{2}}+\frac{\sigma_{6}^{2}}{S^{2}} \leq 1
$$


Onde:

$\sigma_{1}$ é a tensão aplicada na direção da fibra

$\sigma_{2}$ é a tensão aplicada na direção transversal da fibra

$\sigma_{6}$ é a tensão de cisalhamento no plano

$X_{1}$ é a resistência de ruptura à tração longitudinal

$X_{2}$ é a tensão de ruptura à tração transversal

S é a resistência ao cisalhamento no plano

Se as tensões compressivas são envolvidas, então as correspondentes resistências de ruptura à compressão devem ser utilizadas. (CHAWLA, 1987)

Considerando-se novamente uma tensão uniaxial $\sigma_{x}$ aplicada a uma lâmina ortotrópica. Então: (CHAWLA, 1987)

$$
\begin{gathered}
\sigma_{1}=\sigma_{x} m^{2} \\
\sigma_{2}=\sigma_{x} n^{2} \\
\sigma_{6}=\sigma_{x} m n
\end{gathered}
$$

Onde:

$\mathrm{m}=\cos \theta$

$\mathrm{n}=\operatorname{sen} \theta$

Substituindo-se esses valores na equação, se tem: (CHAWLA, 1987)

$$
\frac{m^{4}}{x_{1}^{2}}+\frac{n^{4}}{x_{2}^{2}}+m^{2} n^{2}\left(\frac{1}{s^{2}}-\frac{1}{x_{1}^{2}}\right) \prec \frac{1}{\sigma_{x}^{2}}=\frac{1}{\sigma_{0}^{2}}
$$

Critério da Interação Quadrática: Como o nome indica, este critério leva em conta as interações das tensões. Tsai e Wu propuseram esta modificação da teoria de Hill da lâmina adicionando alguns termos. Tsai e Hahn fornecem uma boa consideração deste critério. De acordo com esta teoria, a superfície de falha no espaço de tensões pode ser descrito como uma função da seguinte forma: (CHAWLA, 1987) 


$$
f(\sigma)=F_{i} \sigma_{i}+F_{i j} \sigma_{i} \sigma_{j} \quad \mathrm{i}, \mathrm{j}=1,2,6
$$

Onde $F_{i}$ e $F_{i j}$ são os parâmetros de força. Para o caso de tensão plana, $\mathrm{i}, \mathrm{j}=1,2,6$ e a equação pode ser descrita da seguinte maneira: (CHAWLA, 1987)

$$
\begin{aligned}
& F_{1} \sigma_{1}+F_{2} \sigma_{2}+F_{6} \sigma_{6}+F_{11} \sigma_{1}^{2}+F_{22} \sigma_{2}^{2}+ \\
& F_{66} \sigma_{6}^{2}+2 F_{12} \sigma_{1} \sigma_{2}+2 F_{16} \sigma_{1} \sigma_{6} \\
& +2 F_{26} \sigma_{2} \sigma_{6}=1
\end{aligned}
$$

Para a lâmina ortotrópica, o sinal invertido para as tensões normais, sejam trativas ou compressivas, é importante. Os termos de tensão linear fornecem essa diferença. Para o componente de tensão cisalhante, o sinal da mesma é irrelevante. Portanto, termos contendo o primeiro grau de tensão de cisalhamento devem ser retirados. Esses termos são $F_{16} \sigma_{1} \sigma_{6}, \quad F_{26} \sigma_{2} \sigma_{6}$ e $F_{6} \sigma_{6}$. Os componentes de tensão não são, em geral, nulos. Portanto, para esses três termos a serem retirados, é preciso ter: (CHAWLA, 1987)

$F_{16}=F_{26}=F_{6}=0$

A equação é simplificada para:

$$
\begin{aligned}
& F_{1} \sigma_{1}+F_{2} \sigma_{2}+F_{11} \sigma_{1}^{2}+F_{22} \sigma_{2}^{2}+ \\
& F_{66} \sigma_{6}^{2}+2 F_{12} \sigma_{1} \sigma_{2}=1
\end{aligned}
$$

No caso de laminados, a definição da falha depende da aplicação. Em algumas aplicações o laminado pode operar satisfatoriamente com determinados tipos de dano. Trincas na matriz ao longo das fibras podem ser toleradas até em estruturas primárias. (ALMEIDA, 2005)

Para o estudo de falha em laminados, o coeficiente de segurança de uma camada para um dado carregamento é definido pela razão entre a carga de falha da camada e a carga aplicada. O índice de falha é calculado para um 
determinado critério de falha (por exemplo Tsai-Wu ou Tsai-Hill). Então, o coeficiente de segurança para uma camada pode ser calculado a partir do seu índice de falha. Há dois critérios básicos para a determinação da resistência de um laminado: a) falha da primeira camada (first ply failure) e b) falha da última camada (last ply failure). (ALMEIDA, 2005)

O critério da falha da primeira camada é de fácil aplicação, mas pode ser extremamente conservador. O critério estabelece que a carga de falha do laminado para um dado carregamento é calculada determinando-se a camada com o maior índice de falha; a carga de falha pode ser calculada a partir do maior índice de falha. Uma falha indicada pelo critério de falha pode ser uma falha na direção transversal de uma única camada e para alguns laminados, esse tipo de falha pode ocorrer para uma carga muito mais baixa que a carga de ruptura do laminado. (ALMEIDA, 2005)

A falha de uma camada implica numa alteração de suas propriedades mecânicas e uma redistribuição de cargas pelas outras camadas e o conseqüente aumento de carga pode causar a falha de outras camadas. A ruptura final do laminado ocorre quando há uma seqüência instável de falhas (falham todas as camadas). (ALMEIDA, 2005)

O critério de falha da ultima camada é de difícil aplicação, mas leva a estimativas mais realistas da carga de fratura do laminado. $O$ critério estabelece que o laminado falha quando todas as camadas do laminado falhem. Os dois elementos básicos para a aplicação do critério de falha da ultima camada são: a) definição do critério de falha de lâmina a ser usado e b) definição de um modelo de degradação das lâminas falhadas. O modelo de degradação das lâminas falhadas é um critério para se alterar as propriedades mecânicas das camadas devido à presença de uma falha. Num modelo muito simples e conservador, as camadas podem ser simplesmente removidas da análise após a falha, isto é, as suas propriedades mecânicas são zeradas (na prática usa-se um número pequeno). A eliminação de uma camada é apropriada no caso de falha das fibras; 
no caso de falha da matriz, esse procedimento pode ser exageradamente conservador. (ALMEIDA, 2005)

Deve-se notar que o critério de Tsai-Hill não indica o tipo de falha na lâmina. O uso desse tipo de critério dificulta a utilização de modelos de degradação. Um modelo de degradação mais elaborado para falha na matriz de uma lâmina seria zerar as seguintes propriedades físicas: $E_{2}, v_{12}, v_{21}, G_{12}, \alpha_{2}, \beta_{2}$. Recalculando-se as tensões nessa camada, os valores de $\sigma_{2}$ e $\tau_{6}$ seriam nulos já que a camada não tem mais rigidez quanto a esses carregamentos. Os critérios de falha estudados fornecem resultados pouco realistas na presença de fortes concentrações de tensões. (ALMEIDA, 2005)

\subsection{Algumas Considerações sobre o Cisalhamento Interlaminar}

Em casos em que a espessura do laminado é pequena se comparada com as suas dimensões laterais, as tensões agindo nos planos interlaminares no interior do laminado (longe das bordas livres) são desprezíveis. É assumido, também, que existe uma aderência perfeita entre quaisquer duas camadas. Desta maneira, as lâminas não serão capazes de escorregarem uma sobre a outra e então, haveria deslocamentos contínuos através da aderência. Outra importante hipótese é feita: uma linha originalmente reta e perpendicular ao plano médio do laminado se mantém da mesma maneira depois da deformação. A partir dessas hipóteses, origina-se a hipótese de Kirchhoff. A hipótese de Kirchhoff determina que os deslocamentos no plano sejam funções lineares da espessura e, conseqüentemente, os deformações devidos ao cisalhamento interlaminar são desprezíveis. Com essa hipótese, é possível reduzir o comportamento de um laminado a uma analise bidimensional do plano médio do laminado. (CHAWLA, 1987)

A análise clássica de materiais laminados, baseada na hipótese de Kirchhoff ignora as deformações por cisalhamento entre as camadas. No entanto, esse ponto tem sido bem explorado por Whitney (1969) e Pagano (1969) em problemas de flexão do material. O comportamento dos materiais compósitos 
laminados sob estado plano de tensões é fortemente influenciado pela presença das tensões de cisalhamento interlaminares, isto é, tensões de cisalhamento distribuídas nas superfícies das camadas laminares. A resistência ao cisalhamento interlaminar pode ser definida como a resistência de um compósito multicamadas a forças internas que induzem o movimento paralelo entre as camadas. (BECKER, 1989)

A resistência ao cisalhamento interlaminar não é uma propriedade mecânica fácil de medir em um compósito laminado. Um grande número de procedimentos de ensaios para medir esta resistência mostra complexidade ao definir esta propriedade. (WILSON, 1989)

\subsection{A Avaliação Experimental das Propriedades da Região Interlaminar de um Compósito}

Não foi desenvolvido ainda um procedimento experimental para compósitos multicamadas que forneça uma tensão ao cisalhamento interlaminar uniforme para uma grande região em uma secção do corpo-de-prova. Concentrações de tensões são formadas nas regiões vizinhas ao campo de tensão cisalhante. Para compósitos fibrosos multidirecionais, o processo de falha mostra tensões cisalhantes interlaminares como as tensões mais críticas a causarem a falha do laminado. Quando o material compósito laminado está submetido a tensões generalizadas no estado plano, as camadas tendem a "escorregar" devido às diferentes constantes elásticas. Como as camadas são conectadas elasticamente pelas suas superfícies, tensões cisalhantes relativas aparecem nas faces de cada camada. Descobriu-se que a seqüência de empilhamento das camadas e orientação das fibras das camadas influencia bastante na iniciação e propagação da delaminação, ou descolamento entre camadas. (ELAWADLY, 2003)

Uma revisão analítica e experimental de dados revela que testes ILSS de 3 pontos e 4 pontos podem apresentar falha por endentação logo abaixo do ponto de aplicação da carga ou falha por flexão antes mesmo de ocorrer a delaminação por cisalhamento interlaminar. $O$ pino de carregamento causa deformação e concentração de tensões compressivas e cisalhantes transversais na região de 
contato. Essas tensões excedem os limites de resistência do material antes da falha interlaminar ocorrer. (ABALI \& SHIVAKUMAR, 2003)

Inúmeras idéias que melhorassem esse tipo de problema foram sugeridas na literatura, como o uso de um pino de carga de maior diâmetro (CUl et al, 1992).

Abali et al. (2003) propuseram introduzir uma fina camada de material macio, por exemplo um elastômero, e sobre esta uma fina camada de alumínio a fim de evitar a indentação na área de apoio do pino de carga. No ensaio proposto por Abali et al. (2003) foi utilizada uma placa de silicone de 1,1 mm de espessura e uma placa de alumínio de $2 \mathrm{~mm}$ de espessura.

Rahhal e Kotlensky (1992), entre outros, desenvolveram um corpo-deprova sanduíche de compósito carbono-carbono (CCC) para evitar o carregamento direto no material (Figura 13). Este modelo de corpo-de-prova apresentou bons resultados ao determinar as tensões cisalhantes interlaminares no compósito.

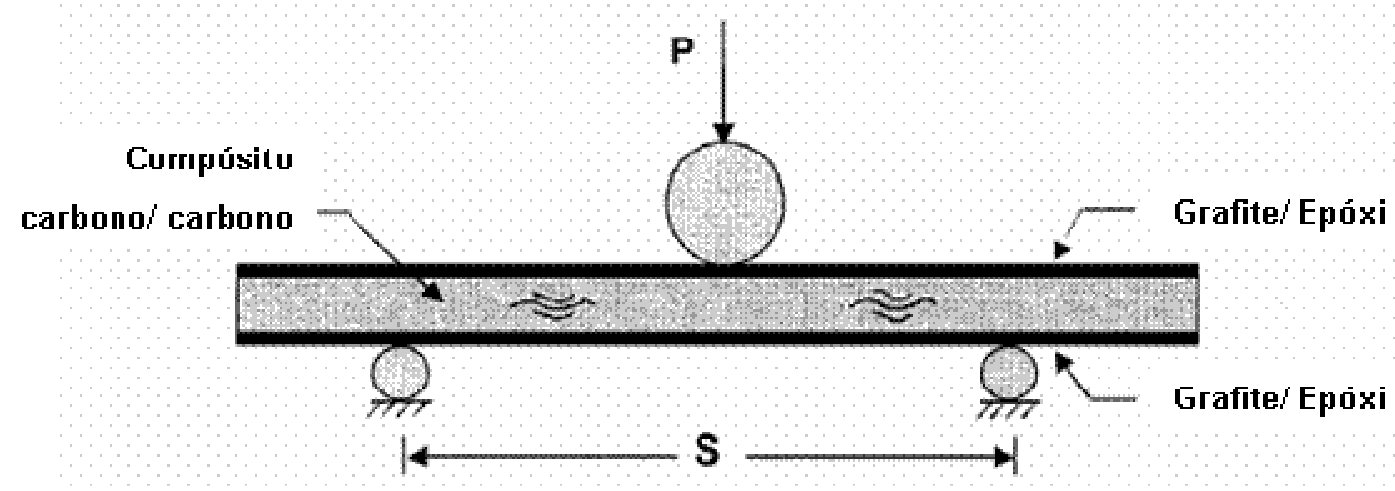

Figura 14: Corpo-de-prova sanduíche para ensaio ILSS.

A partir desses corpos de prova modificados de composto de fibra de carbono com matriz polimérica e com matriz de carbono, testes ILSS em paralelo com análise de contato pelo método dos elementos finitos foram realizados para validar o método proposto. A análise por elementos finitos realizada por Rahhal e 
Kotlensky mostrou que o ensaio ILSS calculado a partir da equação da reta superestima a resistência ao cisalhamento em $5 \%$, tanto para a matriz polimérica como para de carbono. Os dados experimentais dos ensaios realizados por Rahhal e Kotlensky confirmaram a tensão cisalhante interlaminar que causa falha e a pouca dispersão nos dados medidos de resistência. O valor medido no ensaio ILSS do compósito "sanduíche" carbono-carbono T300 (tipo de fibra da fabricante Toray), material testado por Rahhal e Kotlensky, foi de 18,5 MPa; um dos maiores valores relatados na literatura. (RAHHAL \& KOTLENSKY, 1992)

Medidas experimentais realizados por meio da interferometria de franjas de Moiré mostraram uma distribuição descontínua interessante das tensões cisalhantes através da espessura do corpo-de-prova, com picos nas interfaces entre camadas, em que regiões ricas em resina são formadas e a delaminação tende a se originar (POST, 1986).

Joo e Sun estudaram as tensões cisalhantes interlaminares em laminados balanceados e simétricos com bordas livres e as falhas devido a essas tensões. Mostrou-se que a tensão cisalhante interlaminar média próxima à borda livre é linearmente proporcional ao grau de desajuste (mismatch) entre as propriedades elásticas das camadas adjacentes à região interlaminar estudada. (JOO et al, 1992)

Feraboli realizou alguns testes ILSS de 4 pontos em compósitos laminados unidirecionais e multidirecionais, desde materiais quasi-isotrópicos até camadas $0^{\circ}-90^{\circ}$ (cross-ply). Esses ensaios são realizados nas indústrias, mas pouco divulgados na literatura. Um banco de dados experimentais foi formado através da versão modificada do teste ILSS da ASTM D2344 e os resultados mostraram uma proximidade surpreendente de resultados para 3 diferentes arranjos de fibra para um mesmo conjunto de compósito. Várias análises por elementos finitos foram desenvolvidas usando um programa comercial, neste caso, o programa ANSYS, permitindo um maior aprofundamento nos mecanismos de delaminação em uma flexão de 4 pontos, e mostraram resultados bem próximos dos valores experimentais. O modelo final, mais preciso, confirmou parcialmente as observações feitas por outros autores sobre tensões cisalhantes no corpo-de- 
prova e conseguiu mostrar a distribuição dessas tensões através da espessura, sua variação ao longo do comprimento, sua distribuição através da largura, a localização da iniciação da delaminação e propagação, e as regiões de tensões cisalhantes máximas encontradas no ensaio ILSS. (FERABOLI \& KEDWARD, 2003) 


\section{MÉTODO EXPERIMENTAL}

O ensaio ILSS é usado para determinar a tensão de cisalhamento aparente de um plástico reforçado com fibras paralelas. O corpo-de-prova é uma viga curta que corresponde a um pequeno segmento tirado de um anel ou uma chapa plana de laminado de até $6,4 \mathrm{~mm}$ de espessura. Este método é aplicável para todos os tipos de compósitos reforçados com fibras paralelas (ASTM D2344/D2344M, 2000).

O teste realizado é aquele de 3 pontos e foi realizado no Laboratório de Comportamento Mecânico do CTM (Centro Tecnológico da Marinha). As observações microestruturais, ópticas e eletrônicas foram realizadas no Laboratório de Microscopia e Microanálise do CCTM/ Ipen (Centro de Ciência e Tecnologia de Materiais).

\subsection{Aparato e condições de teste}

O equipamento de teste, propriamente calibrado, opera com um movimento de velocidade constante do cabeçote. A velocidade de movimento do cabeçote utilizado foi $1,3 \mathrm{~mm} \cdot \mathrm{min}^{-1}$. O sistema de medida da carga não pode exceder um erro de $\pm 1 \%$. A Figura 15 ilustra um dispositivo típico de ensaio ILSS.

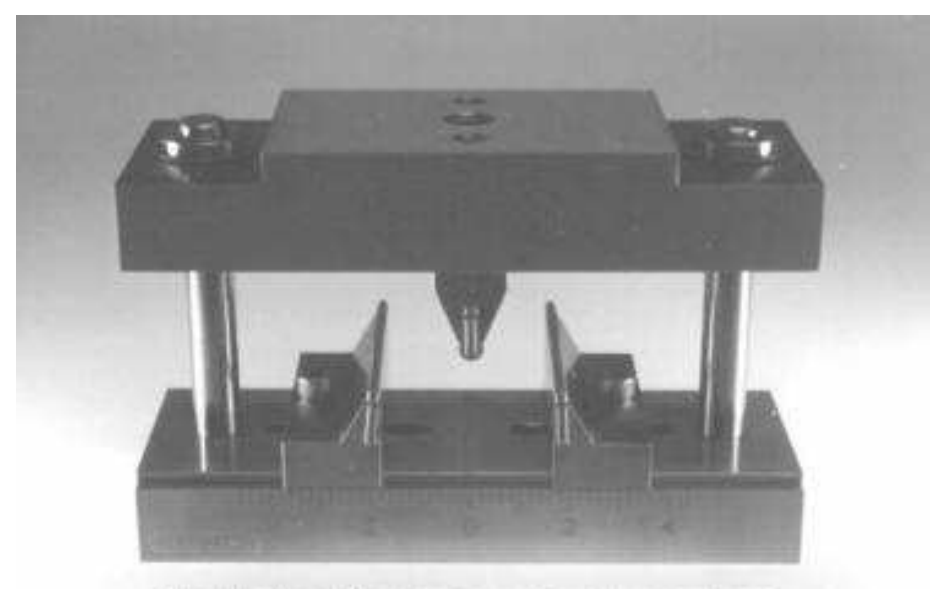

Figura 15: Dispositivo típico de ensaio ILSS. 
A máquina de ensaio exerce uma carga no corpo-de-prova por meio do cilindro do dispositivo de ensaio. O cilindro de carga tem $6,35 \mathrm{~mm}$ de diâmetro, com dureza entre 60 e 62 HRC. Sua superfície deve ser livre de endentações e rebarbas, com todos os cantos vivos suavizados. Os suportes consistem em dois cilindros de $3,2 \mathrm{~mm}$ de diâmetro, dispostos sob o corpo-de-prova conforme a Figura 16 .

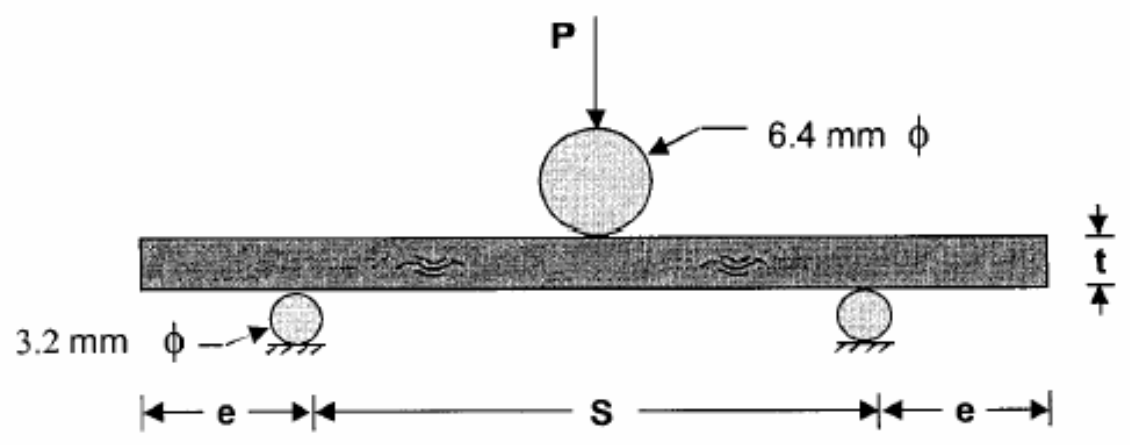

Figura 16: Ensaio ILSS de 3 pontos.

A distância entre os suportes é tipicamente conhecida pela palavra em inglês span. Doravante, esse comprimento será referenciado pela palavra span por ser largamente utilizada. $O$ valor do span durante os ensaios deve seguir a norma ASTM D 2344, conforme mostra a Tabela 1.

Tabela 1: Razão span/ espessura e comprimento/ espessura.

\begin{tabular}{|l|c|c|}
\hline \multicolumn{1}{|c|}{ Reforço } & span/ espessura & comprimento/ espessura \\
\hline Fibra de vidro & 5 & 7 \\
\hline Fibra de carbono & 4 & 6 \\
\hline Arame de aço & 4 & 6 \\
\hline Filamentos de Boro & 4 & 6 \\
\hline Aramida & 4 & 6 \\
\hline
\end{tabular}

uavizados.ntos vivos d), livre de identacao e burrs, com todas com um

movimento de velocidade constante do crosshead

Um micrômetro, de ponta esférica adequado, deve apresentar leitura de pelo menos $0,025 \mathrm{~mm}$ por medida de largura, espessura e comprimento do corpode-prova. 
A temperatura ambiente da sala em que o teste é feito deve ser mantida a $23^{\circ} \mathrm{C} \pm 1^{\circ} \mathrm{C}$ e umidade relativa de $50 \pm 10 \%$. 


\subsection{Corpo-de-prova}

O corpo-de-prova pode ser plano ou anelar. Para o ensaio usado no presente estudo, foi usado o corpo-de-prova plano. A espessura do corpo-deprova não deve ultrapassar $6,4 \mathrm{~mm}$, segundo orientação da norma ASTM D2344. O corpo-de-prova é mostrado na Figura 17.

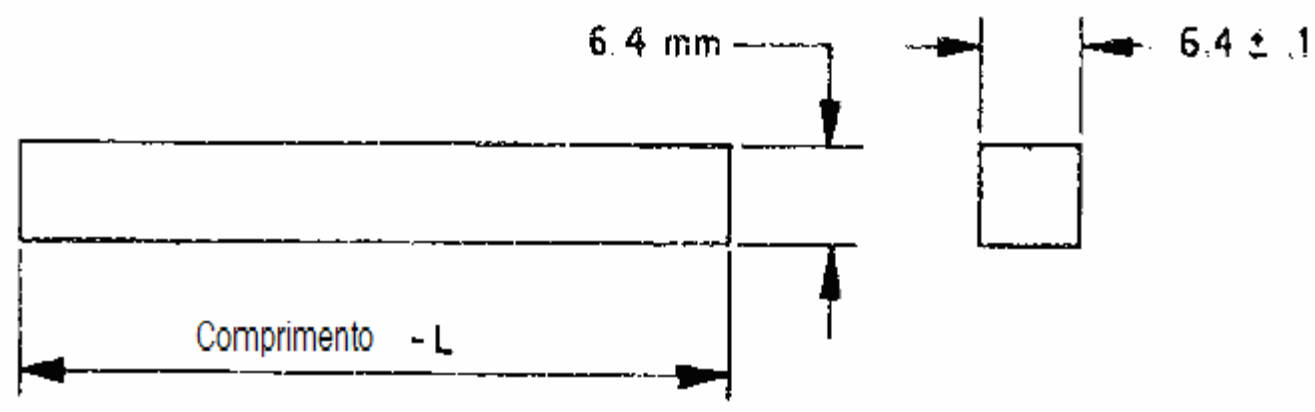

Figura 17: Corpo-de-prova plano para ILSS.

As dimensões do corpo-de-prova devem obedecer às relações da Tabela 1 anterior.

Foram utilizados 9 corpos de prova para o teste. Os corpos de prova são unidirecionais e têm comprimento $27 \mathrm{~mm}$, largura de $6,5 \mathrm{~mm}$ e espessura de 3,5 $\mathrm{mm}$. Como a Tabela 1 determina uma razão de 4 entre o span e a espessura, isso significa que o span deve ser de $14 \mathrm{~mm}$, já que a espessura do corpo-de-prova é $3,5 \mathrm{~mm}$. São compostos de 22 camadas de fibra de carbono T300 6k e matriz de resina epóxi. A nomenclatura T300 corresponde a um tipo de fio de fibra de carbono fabricado pela Toray, com a gramatura da fibra é de $400 \mathrm{~g} / \mathrm{m}^{2}$ e a nomenclatura $6 \mathrm{k}$ significa que cada fio contém 6000 monofilamentos. A composição volumétrica do compósito é de $68 \%$ de fibra de carbono. 


\subsection{Procedimento}

Primeiramente, marca-se com precisão a linha central no comprimento, onde a carga será aplicada. Posiciona-se o corpo-de-prova sobre os suportes com o span sugerido pela norma (14 mm).

Aplica-se, então, o carregamento ao corpo-de-prova na taxa de movimento especificada. Acompanhando a curva de carga (tensão) x deformação, determina-se quando ocorreu a falha por meio de uma queda abrupta na curva. Um exemplo da forma típica dessa curva é mostrado na Figura 18 :

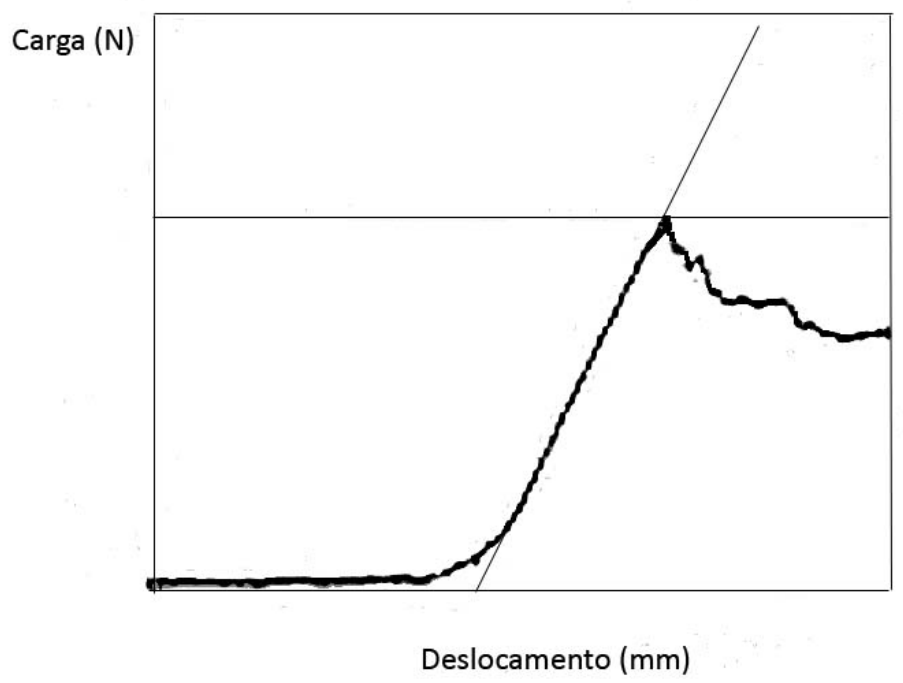

Figura 18: Exemplo de curva carga $\mathrm{x}$ deslocamento fornecida pelo teste ILSS.

\subsection{Resultados do teste}

Os valores das cargas de ruptura, assim como o valor da tensão de cisalhamento para a carga de ruptura correspondente são listados na Tabela 2 . 
Tabela 2: Resultados do ensaio ILSS.

\begin{tabular}{|c|c|c|}
\hline $\mathbf{C P}$ & $\begin{array}{c}\mathbf{S}_{\mathbf{H}} \\
(\mathbf{M P a})\end{array}$ & $\begin{array}{c}\mathbf{P}_{\mathbf{b}} \\
\mathbf{( N )}\end{array}$ \\
\hline 1 & 73 & 2195 \\
\hline 2 & 86 & 2580 \\
\hline 3 & 69 & 2066 \\
\hline 4 & 74 & 2255 \\
\hline 5 & 68 & 2078 \\
\hline 6 & 74 & 2259 \\
\hline 7 & 67 & 2001 \\
\hline 8 & 70 & 2110 \\
\hline 9 & 68 & 2054 \\
\hline $\begin{array}{c}\text { Média e } \\
\text { desvio } \\
\text { padrão }\end{array}$ & $72 \pm 6$ & 2178 \\
\hline
\end{tabular}

A tensão de cisalhamento é determinada conforme a Teoria de Viga (ASTM D2344/D2344M, 2000).

$$
\mathrm{S}_{\mathrm{H}}=\frac{0,75 \mathrm{P}_{\mathrm{b}}}{\mathrm{w} \cdot \mathrm{t}}
$$

Onde:

$\mathrm{S}_{\mathrm{H}}=$ tensão de cisalhamento, em MPa

$\mathrm{P}_{\mathrm{b}}=$ carga de falha, em $\mathrm{N}$

$\mathrm{w}=$ largura do corpo-de-prova, em $\mathrm{mm}$

$\mathrm{t}=$ espessura do corpo-de-prova, em $\mathrm{mm}$ 


\section{MÉTODO NUMÉRICO}

\subsection{Breve Histórico}

O método dos elementos finitos tem suas origens nos anos 40 , tendo sido, entretanto, vastamente utilizado apenas nos últimos vinte e cinco anos, graças aos avanços tecnológicos ocorridos nos equipamentos computacionais. O método consiste basicamente numa adaptação/ modificação de métodos de aproximação conhecidos, já no início deste século, como, por exemplo, o método de Ritz, estabelecido em 1909. É atualmente considerado um método matemático para a solução de equações diferenciais parciais, entre as quais se inclui a Equação de Poisson, Equação de Laplace, Equação de Helmholtz, Navier-Stokes, entre outros. Devido às suas características de flexibilidade e estabilidade numérica, ele pode ser implementado na forma de um sistema computacional (programa de computador), de forma consistente e sistemática. (ALVES, 2002)

O método é largamente usado para analisar e projetar condições de trabalho ou geometrias nem formuladas em normas nem em cálculos tradicionais analíticos. Devido à utilidade e interesse para diversas áreas técnicas, o método dos elementos finitos tem sido objeto de inúmeros artigos e livros publicados nos últimos anos, sendo também, incluído como disciplina da grande maioria das universidades. À medida que técnicas computacionais e numéricas desempenham um papel cada vez mais relevante na vida do engenheiro, torna-se fundamental o conhecimento dos fundamentos do método dos elementos finitos e da sua aplicação prática, especialmente para aqueles que trabalham em áreas de projeto e análise. No entanto, o número de trabalhos feitos sobre materiais compósitos utilizando o método dos elementos finitos ainda é relativamente restrito. Por esses motivos, será de extrema vantagem o uso do método numérico para que seus resultados sejam comparados aos resultados do método experimental.

Jen et al. (1993) desenvolveram um modelo matemático para estudar as tensões e singularidades nas bordas interlaminares em um compósito laminado pré-trincado e prever a iniciação da delaminação. Os autores determinaram que a 
localização da delaminação e trincamento da matriz coincide com as interfaces com maiores tesões cisalhante e normal, conforme seu modelo. (JEN et al, 1993)

\subsection{Metodologia}

O método numérico usado na avaliação das tensões cisalhantes interlaminares foi o método dos elementos finitos. O método numérico tem a grande vantagem de ser um método não-destrutivo de avaliação da integridade estrutural de componentes e equipamentos. O programa utilizado para a modelagem e simulação do teste ILSS no presente estudo foi o ANSYS Rev. 10.0.

O processo de análise por elementos finitos é dividido em três etapas: préprocessamento, processamento (ou solução) e pós-processamento.

Etapa de pré-processamento: Essa é a etapa que precede a solução matemática, possuindo especial importância, pois é nela onde o modelo é concebido. No pré-processamento serão seguidos cuidadosamente os seguintes passos:

i. O modelamento, ou seja, o desenho da geometria.

Selecionar o tipo de elemento finito para discretizar o modelo e gerar a malha. A geração da malha consiste em dividir a geometria em nós e elementos. O programa ANSYS, usado no presente estudo, possui uma vasta biblioteca de diferentes elementos finitos. Cada tipo de elemento finito possui uma formulação matemática específica, a qual é responsável pela informação que o elemento oferece (deslocamentos, rotações, tensões, deformações). Os elementos são formados por nós e o conjunto de elemento que leva o nome de malha. Os nós de um modelo, por serem dependentes entre si, formam equações de deslocamentos que servem para compor a matriz global de rigidez para a resolução simultânea de todas essas equações. No desenvolvimento do presente estudo, foram selecionados dois tipos de elementos finitos e, conseqüentemente, dois tipos de modelamento: modelo 
plano e modelo de casca. A Figura 19 mostra um exemplo de um modelo discretizado e sua malha de elementos finitos e respectivos nós.

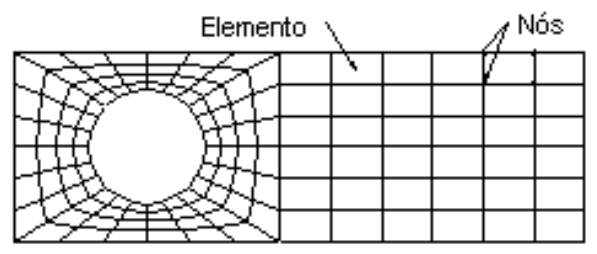

Figura 19: Exemplo de modelo e malha de elementos finitos.

Quanto maior a quantidade de nós, maior a quantidade de elementos finitos e, conseqüentemente, mais refinada é a malha. Nas regiões do modelo em que costuma ocorrer concentração de tensões, como, por exemplo, nas regiões de contato, transições geométricas e de aplicação de carga pontual, onde há um gradiente maior de variação de tensões, recomenda-se um maior refinamento da malha, que leva a uma maior precisão dos resultados. No presente estudo, as regiões de contato foram modeladas com uma malha de elementos finitos mais refinada que o restante do modelo.

ii. Definir as chamadas constantes reais (área, momento de inércia, espessura) para o elemento finito utilizado;

iii. Definir as propriedades mecânicas e os modelos que descrevem apropriadamente o comportamento do elemento finito que conforma a simulação. Neste projeto será feita uma análise linear estática.

iv. Criar a geometria dos modelos. Neste projeto as peças serão modeladas respeitando-se a sua tridimensionalidade, através de um modelo bidimensional, com espessura aplicada.

v. Discretizar os elementos que compõem o modelo, ou seja, definir a "malha" de elementos finitos a ser utilizada. Nesta fase é importante levar em consideração que uma malha mais fina pode oferecer (não necessariamente) melhores resultados, porém, o tempo de cálculo seria 
maior. Uma malha mais grossa pode simplificar a execução do modelo, mais poderia comprometer a qualidade dos resultados.

vi. Definir e aplicar as cargas externas atuantes na estrutura ao modelo assim como as condições de contorno ou fronteira (apoios ou vínculos).

Etapa de processamento: Enquanto a etapa de pré-processamento é inteiramente interativa com o usuário, a etapa de processamento é realizada pelo programa. Após carregar o programa com todas as informações necessárias e acionar o comando que soluciona a análise, o programa deverá acusar se a solução está completa e se apresentou algum problema ou não. Nesta etapa da análise, o programa encarrega-se de calcular a matriz de rigidez, para que sejam calculados posteriormente os deslocamentos nodais e as tensões. Uma vez que a solução está completa e sem erros pode-se passar para a última etapa, a etapa de pós-processamento.

Finalmente, a etapa de pós-processamento é aquela que exibe os resultados. $\mathrm{Na}$ etapa de pós-processamento é possível visualizar, através do programa ANSYS, diversas informações como tensões e deformações.

Etapa de pós-processamento: Esta etapa é muito importante, pois no pósprocessamento serão visualizados os deslocamentos, as tensões, temperaturas e todas as demais informações que se deseja obter. A visualização dos resultados é feito por meio de uma interface gráfica que ilustra o modelo de análise em uma escala de cores que representa a distribuição das faixas de valores avaliados.

As tensões e deformações que serão mostradas em ilustrações nos itens adiante são resultados nodais. O resultado nodal consiste em fazer, em cada nó do modelo, uma media dos resultados de todos os elementos finitos que contêm este nó. 


\subsection{Aplicações do Método}

Inicialmente, na década de 60, o método dos elementos finitos era usado em cálculo estrutural e hoje é largamente aplicado em problemas de campo (calor, fluidos, campo elétrico e magnético). Alguns exemplos de análises que podem ser executadas empregando-se o método dos elementos finitos: (NEGRETTI, 2006)

- Análise estática linear de tensões e deformações (edifícios, pontes, torres, tubulações industriais, componentes mecânicos em geral);

- Análise dinâmica (modos de vibração e freqüências naturais);

- Análise não-linear de tensões e deformações (conformação, grandes deformações);

- Análise térmica (transmissão de calor em regime permanente ou transiente);

- Análise de tensões devido ao carregamento térmico (tubulações industriais);

- Escoamento de fluídos (aerodinâmica, hidrodinâmica);

- Campos elétricos (condutores, isolantes, eletrodeposição e corrosão) e magnéticos.

\subsection{Nomenclatura}

O modelo de elementos finitos é composto por elementos conectados entre si, por nós, formando a malha de elementos finitos, conforme ilustra a Figura 20 :

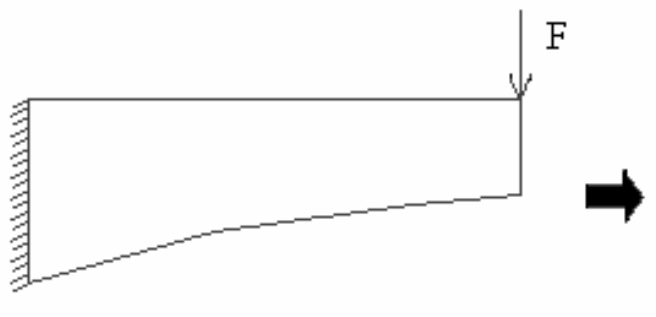

Situação Real

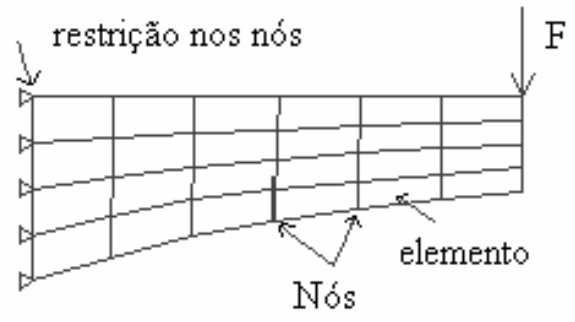

Modelo Elementos Finitos

Figura 20: Modelo de elementos finitos. 
$\mathrm{Na}$ análise de tensões e deformações, cada nó possui até seis graus de liberdade (GL) em relação ao sistema de coordenadas cartesianas globais, dependendo do tipo de elemento. Um grau de liberdade é a possibilidade que um nó tem de rotacionar ou de se transladar em relação a um eixo de coordenadas, conforme ilustrado na Figura 21.

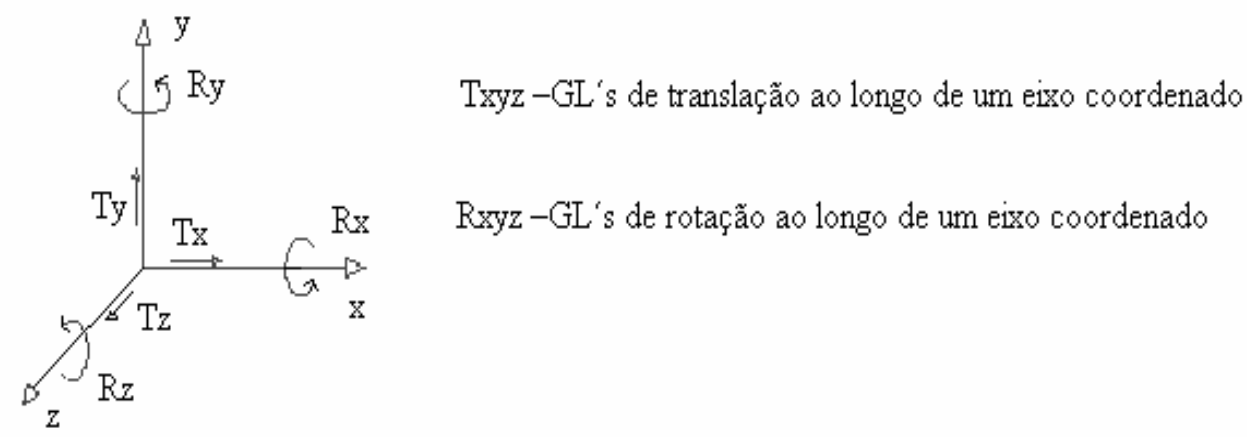

Figura 21: Graus de liberdade de um nó.

\subsection{Formulação Matemática}

Dividir uma estrutura em elementos era quase natural. Nas análises estruturais era também natural o conceito de elemento, principalmente em treliças e vigas rebitadas ou soldadas. A estrutura real é transformada matematicamente em uma série de elementos do tipo "mola". A relação matemática que descreve força versus deslocamento para uma única mola é conhecida como a lei de Hooke:

$$
\sigma=E^{*} \varepsilon
$$

Onde:

$\sigma=$ Tensão;

$E=$ Módulo de Elasticidade de primeira ordem ou Módulo de Young;

$\varepsilon=$ Deformação específica.

Ao se colocar uma proteção imaginária na "mola", e defini-la como "domínio", a interrogante será: quais são as influências externas? Isto mostrará que as influências externas são as forças atuantes nos nós. A resposta do 
sistema para a força é a deflexão, ou seja, as influências externas, neste caso, as forças, produzem as incógnitas primárias: os deslocamentos. Considere este "domínio" como um sistema de entrada e saída. (NEGRETTI, 2006)

Como exemplo de aplicação do método em tensão-deformação será apresentado à analogia de uma mola com uma barra carregada axialmente:
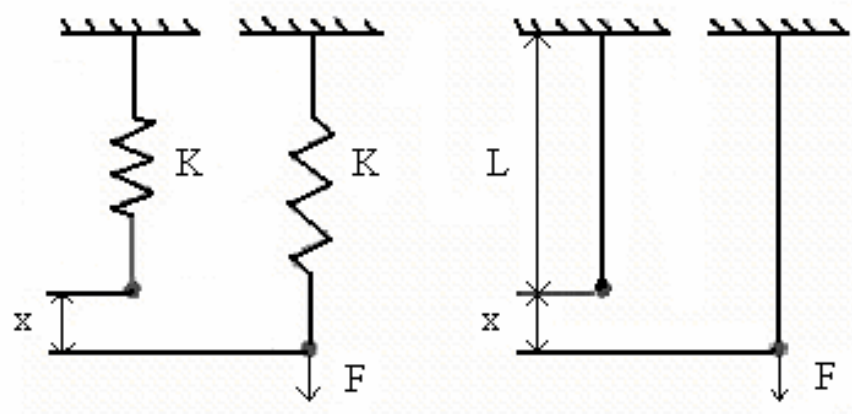

Figura 22: Analogia Mola/ Barra.

Da Figura 22 e da resistência dos materiais vêm:

$$
\begin{array}{r}
\sigma=\frac{F}{A} \rightarrow \text { Tensão } \\
\sigma=E^{*} \varepsilon \rightarrow \text { Lei de Hooke } \\
\varepsilon=\frac{x}{L} \rightarrow \text { Deformação }
\end{array}
$$

Então:

$$
F=\left[\left(\frac{E^{*} A}{L}\right) * x\right] \rightarrow\left(\frac{E^{*} A}{L}\right)=K
$$

Onde

$\mathrm{K}=$ Constante de rigidez da mola 


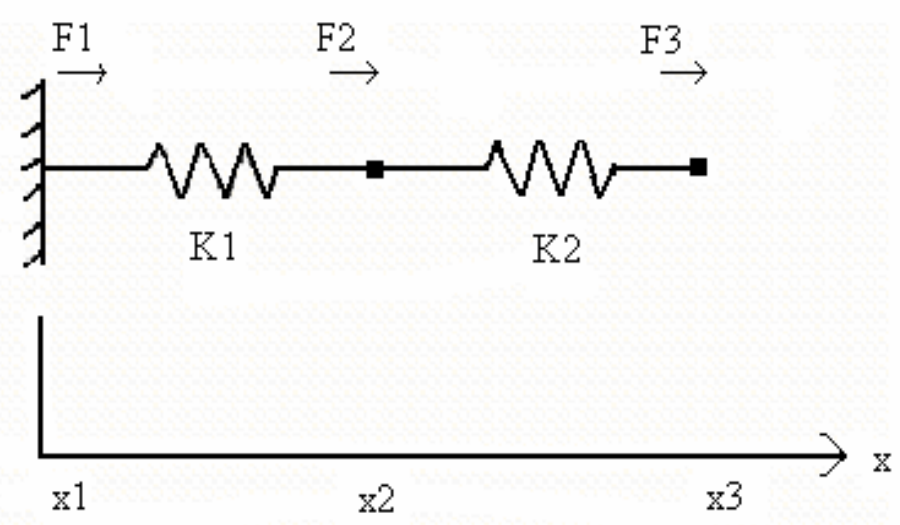

Figura 23: Sistema com duas molas

Sistema de equações que representa a situação da Figura 23.

$$
\left\{\begin{array}{l}
F 1=K 1 *(x 1-x 2) \\
F 2=[(K 1+K 2) * x 2]-(K 1 * x 1)-(K 2 * x 3) \\
F 3=K 2 *(-x 2+x 3)
\end{array}\right.
$$

Análise matricial do sistema de equações:

$$
\begin{gathered}
\left\{\begin{array}{l}
F 1 \\
F 2 \\
F 3
\end{array}\right\}=\left\{\begin{array}{lll}
K 1 & -K 1 & 0 \\
-K 1 & K 1+K 2 & -K 2 \\
0 & -K 2 & K 2
\end{array}\right\} *\left\{\begin{array}{l}
x 1 \\
x 2 \\
x 3
\end{array}\right\} \\
\{F\}=\{K\} *\{x\}
\end{gathered}
$$

onde:

$\mathrm{K}=$ matriz de rigidez do sistema.

A variável primária (o vetor deslocamento) é resolvida pela inversão da matriz $\mathrm{K}$.

$$
\{x\}=\{K\}^{-1 *}\{F\} \quad \text { (Equação 5.7) }
$$


O exemplo das molas é um tanto elementar. A estrutura de uma ponte é um exemplo prático muito mais interessante. No caso, a estrutura é modelada empregando-se elementos de treliça. (NEGRETTI, 2006)

A treliça permite deslocamentos em duas direções ( $u$ e v) em cada nó. Neste caso, a matriz de rigidez do modelo é uma matriz de $4 \times 4$. Quando os elementos são de ordem superior, a matriz de rigidez também se torna mais complexa. Para elementos simples a matriz de rigidez pode ser escrita por meio de expressões analíticas. Para elementos mais complexos, ela é freqüentemente avaliada numericamente. Para efetuar uma análise por elementos finitos, o problema principal é achar e resolver estas matrizes. (NEGRETTI, 2006)

Em programas comerciais, a solução desta matriz não apresenta dificuldades ao usuário, pois geralmente estes programas oferecem uma ampla biblioteca de elementos finitos para os quais eles podem montar e resolver a matriz de rigidez. (NEGRETTI, 2006)

Uma vez selecionado um elemento, todo o sistema ou a equação principal é montado levando em consideração a formulação matemática do mesmo. A montagem é feita pela inserção do elemento matricial na respectiva linha e coluna da matriz. Este processo de montagem é facilmente efetuado pelo computador. Finalmente a equação principal é resolvida, obtendo-se a incógnita primária, o vetor de deslocamento, $\{d\}$. (NEGRETTI, 2006)

$$
\{d\}=\{K\} *\{F\}
$$

Simbolicamente, mostra-se isto pela inversão da matriz $\{K\}$. Porém na prática, a maioria dos programas comerciais usa o método de eliminação de Gauss. O método da eliminação de Gauss consiste em reduzir um sistema com certo número de equações e de incógnitas a um sistema com uma equação e uma incógnita a menos, usando uma das equações para eliminar uma das incógnitas das demais equações. Isto é, uma das incógnitas é achada, e as incógnitas restantes encontradas por substituição inversa, ou seja, substitui-se o valor da incógnita, e assim sucessivamente. (NEGRETTI, 2006) 


\subsection{Propriedades dos Materiais}

As propriedades dos materiais usadas nas análises de tensões foram tiradas da referência LEITÃO (2007), já que o material estudado nesta foi o mesmo dos corpos-de-prova do presente estudo. A Tabela 3 lista as propriedades.

Tabela 3: Propriedades

\begin{tabular}{|l|c|c|c|c|c|c|c|}
\cline { 2 - 8 } \multicolumn{1}{c|}{} & $\begin{array}{c}\text { Ex } \\
{[\mathrm{MPa}]}\end{array}$ & $\begin{array}{c}\mathrm{Ey} \\
{[\mathrm{MPa}]}\end{array}$ & $\begin{array}{c}\mathrm{Ez} \\
{[\mathrm{MPa}]}\end{array}$ & $\boldsymbol{v}_{\mathrm{xy}}$ & $\boldsymbol{v}_{\mathrm{yz}}$ & $\boldsymbol{v}_{\mathrm{xz}}$ & $\begin{array}{c}\mathbf{G x y} \\
{[\mathrm{MPa}]}\end{array}$ \\
\hline Carbono/ epóxi & 153000 & 10500 & 10500 & 0.3 & 0.3 & 0.3 & 6500 \\
\hline Epóxi & 3500 & 3500 & 3500 & 0.34 & 0.34 & 0.34 & \\
\hline Aço carbono & 203400 & 203400 & 203400 & 0.3 & 0.3 & 0.3 & \\
\hline
\end{tabular}

Essas são as propriedades usadas em todas as duas modelagens em elementos finitos.

\subsection{Modelo Plano}

O modelo plano considera estado plano de tensões e representa as 22 camadas e regiões entre camadas com elementos finitos planos "PLANE183", assim como o pino de carregamento e suportes. Foram modelados também os elementos finitos de contato "TARGET169" e "CONTA172" entre o corpo-de-prova e o pino de carregamento, e o corpo-de-prova e o cilindro de suporte.

Um maior detalhamento desses elementos será feito a seguir:

PLANE183: É um elemento finito bidimensional de 8 nós. Este elemento finito tem um comportamento de deslocamento quadrático e é indicado para modelar malhas irregulares. Este elemento finito é definido por 8 nós, tendo dois graus de liberdade em cada nó - translações nas direções $x$ e y. $O$ elemento pode ser usado como elemento finito plano (estado plano de tensões ou estado plano de deformações) ou em elementos finitos axissimétricos. Este elemento tem plasticidade, hiperelasticidade, fluência, capacidade de considerar rigidez causada por deformação e de considerar grades deflexões e de grandes 
deformações. O elemento, além de quadricular, pode ser triangular, no qual três dos nós têm a mesma localização (como se fosse um total de 6 nós). Além dos nós, outro dado de entrada do elemento é a espessura. A Figura 24 ilustra os elementos finitos quadrático e triangular e o sistema de coordenadas que orienta o elemento finito no programa ANSYS: (ANSYS TUTORIAL, 2006)

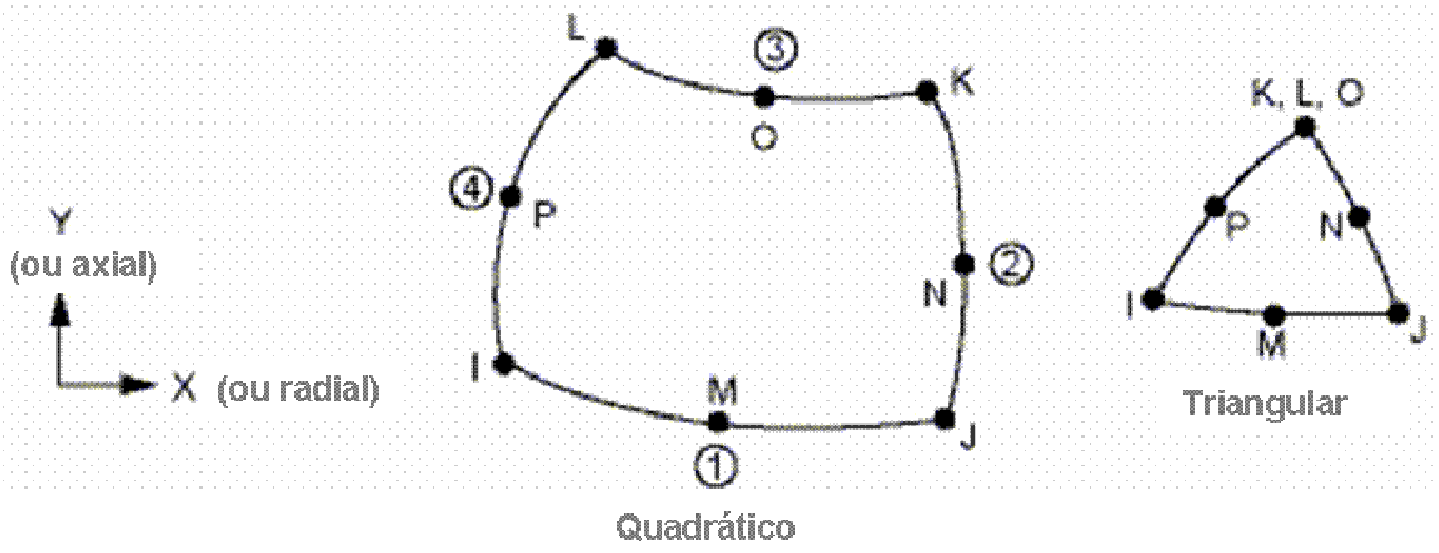

Figura 24: Elemento finito plano PLANE183

TARGET169: Este elemento finito é usado para representar uma das superfícies de contato. No contato, existe a superfície de contato e a superfície alvo (TARGET169). O elemento finito TARGET169 pode trabalhar como alvo de três outras opções de contato: CONTA171, CONTA172 ou CONTA175. No presente estudo, a superfície de contato usou elementos finitos CONTA172. Os próprios elementos finitos de contato sobrepõem os elementos finitos alvo sólidos, descrevendo o contorno de um corpo deformado e estão potencialmente em contato com a superfície alvo de contato, definido pelo TARGET169. A superfície alvo de contato com os elementos finitos TARGET169 são discretizados por um conjunto de elementos finitos segmentados que emparelham uns com os outros da outra superfície de contato. A Figura 25 ilustra o elemento finito TARGET169 e seu correspondente CONTA172 e suas orientações conforme o programa ANSYS. 


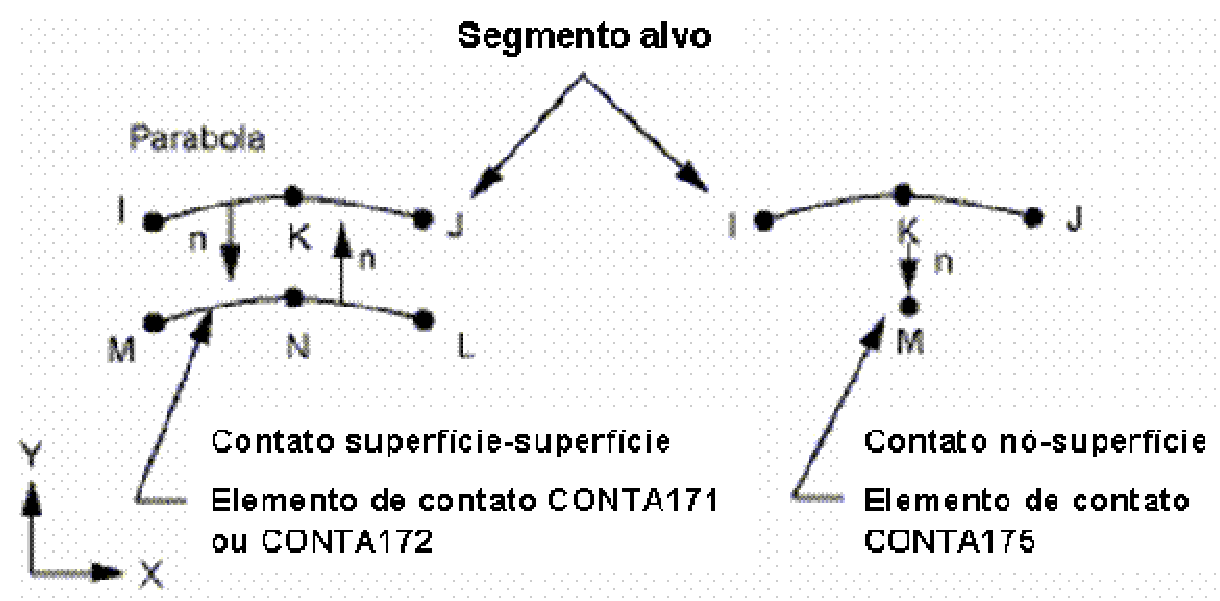

Figura 25: Elemento finito de contato TARGE169

A superfície alvo é modelada através de um conjunto de segmentos-alvo que se ligam, tipicamente, com os segmentos-contato da superfície de contato. (ANSYS TUTORIAL, 2006)

Determinando-se qual a superfície alvo do contato e qual a superfície de contato, é possível modelar uma superfície respectivamente deformável e uma rígida. No modelo do presente estudo, o elemento finito TARGE169 corresponde à região de contato do corpo-de-prova de fibra de carbono. (ANSYS TUTORIAL, 2006)

CONTA172: Esse elemento finito é usado para representar contato entre superfícies bidimensionais. Este elemento finito é aplicado a estruturas bidimensionais que possuem nó intermediário (PLANE2, PLANE 21, PLANE183, SHELL209, PLANE82, VISCO88, VOSC0108, PLANE35, PLANE223, PLANE230 ou MATRIX50). Tem as mesmas características da face do elemento finito sólido a que está conectado. O contato ocorre quando o elemento finito CONTA172 penetra em um dos elementos finitos de contato alvo (TARGE169) correspondentes. A Figura 26 ilustra o elemento finito CONTA172 e o sistema de coordenadas que orienta o elemento finito no programa ANSYS: 


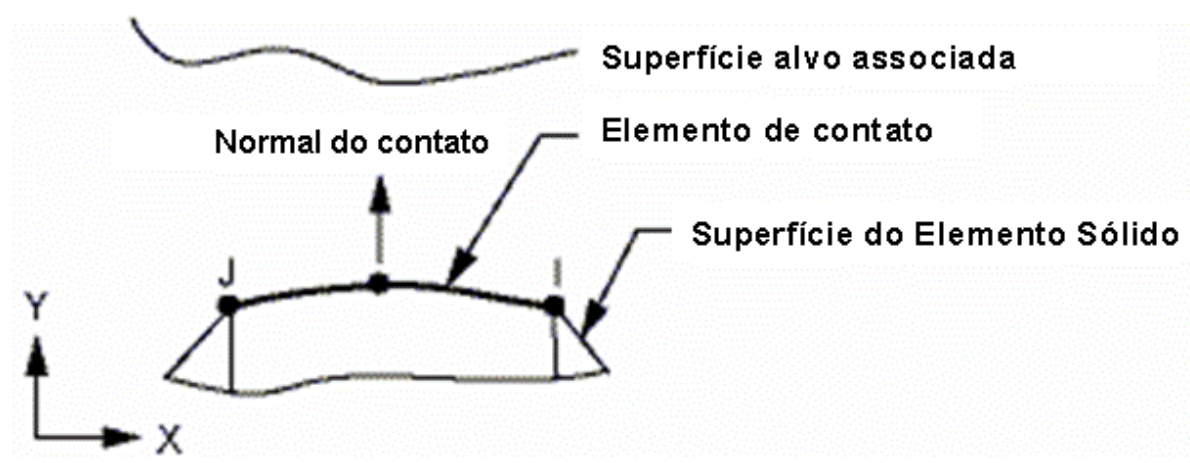

Figura 26: Elemento finito de contato CONTA172

O modelo plano representa $1 / 2$ da geometria, aproveitando o plano de simetria yz. Desta maneira, a força aplicada deve ser $1 / 2$ da força total e as condições de contorno aplicadas devem ser aquelas de simetria.

O cilindro de suporte foi modelado com apenas $1 / 2$ da sua geometria, pois a parte inferior deste cilindro não trabalha, ou seja, não afeta o resultado. A extremidade do cilindro de suporte recebeu a condição de contorno de apoio, ou seja, foi restrito o movimento vertical (direção y) dos nós desta região.

A partir de observação por microscópio óptico, estima-se que 1/12 da espessura de cada camada corresponda à fina camada de matriz polimérica existente na região interlaminar. Cada uma das 22 camadas interlaminares foi modelada com 11/12 da espessura com as propriedades do compósito de fibra de carbono unidirecional/ epóxi, e 1/12 da espessura foi modelada com as propriedades da matriz polimérica (propriedades do epóxi).

Os cilindros de carga e suporte foram modelados com as propriedades do aço carbono. A carga de ruptura do teste, de $2178 \mathrm{~N}$, foi aplicada na superfície superior do cilindro de carga. Como o modelo é simétrico, então, essa carga é de 1089 N. A análise é estática e linear.

A Figura 27 ilustra o modelo de elementos finitos, utilizando uma simbologia de cores especificada na Tabela 4. A cor amarela corresponde ao epóxi puro (fina camada interlaminar), a cor laranja representa o compósito 
carbono/ epóxi e a cor azul representa o aço carbono. A figura também mostra o valor e local de aplicação da carga e as condições de contorno.

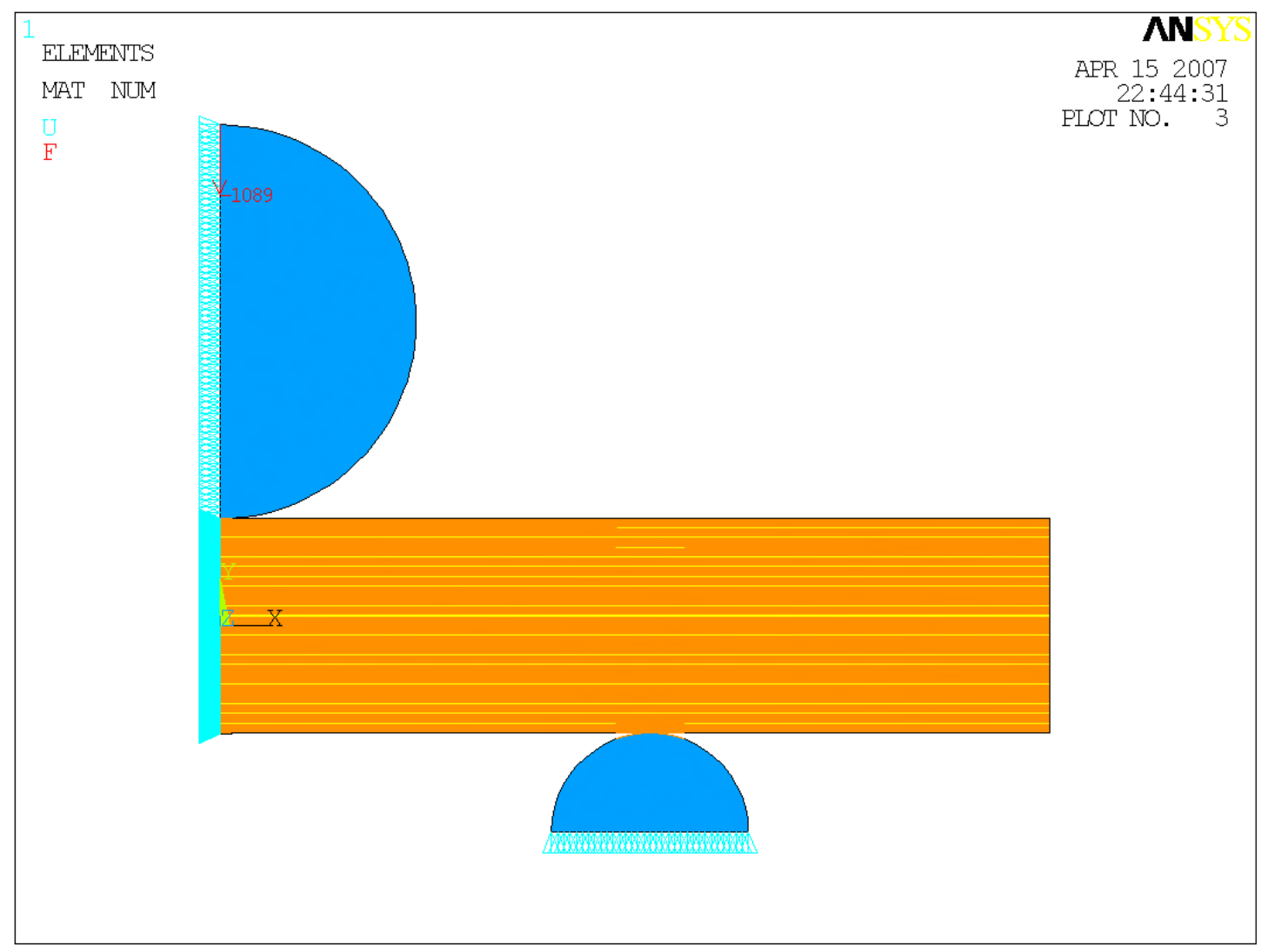

Figura 27: Modelo plano

Tabela 4: Definição de cores do modelo plano

\begin{tabular}{|c|l|}
\hline Cor & \multicolumn{1}{c|}{ Definição } \\
\hline Cor-de-laranja & $\begin{array}{l}\text { Elementos finitos planos que representam as camadas } \\
\text { carbono/ epóxi }\end{array}$ \\
\hline Amarela & $\begin{array}{l}\text { Elementos finitos planos que representam as camadas } \\
\text { de matriz polimérica pura (epóxi puro) }\end{array}$ \\
\hline Azul & $\begin{array}{l}\text { Elementos finitos planos que representam componentes } \\
\text { de aço carbono }\end{array}$ \\
\hline Cyan (verde-água) & $\begin{array}{l}\text { Condições de contorno: restrição em y no cilindro de } \\
\text { suporte e restrição em x no plano de simetria do } \\
\text { modelo. }\end{array}$ \\
\hline
\end{tabular}


Na Figura 28 é possível distinguir as camadas amarelas (epóxi puro) das camadas cor-de-laranja (carbono/ epóxi).

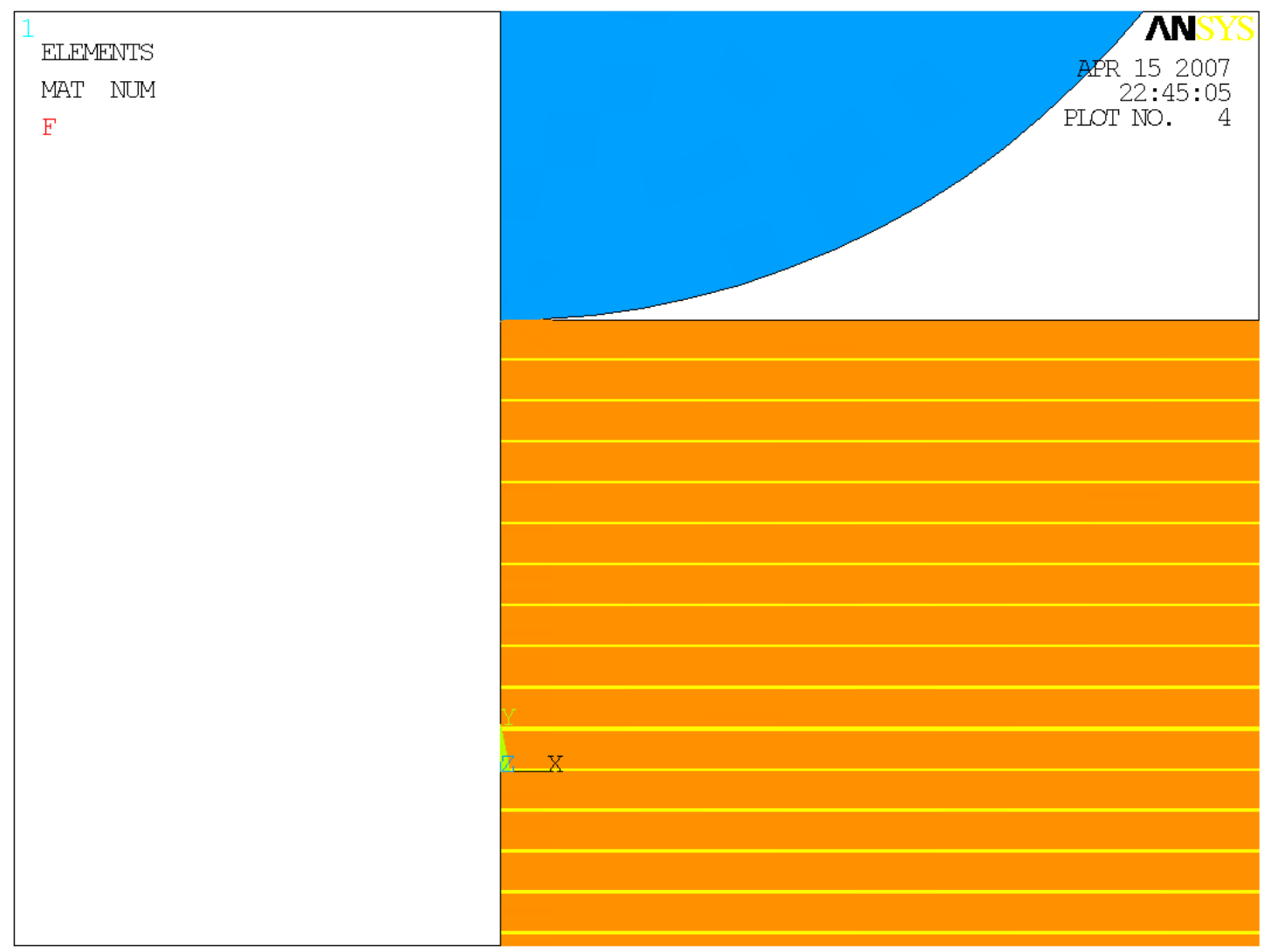

Figura 28: Plotagem para melhor visualização das camadas de epóxi puro e das camadas de fibra de carbono + epóxi

A geração da malha de elementos para este modelo passou por uma análise de sensibilidade. Isso significa que várias malhas com diferentes tamanhos de elementos foram testadas para a adequação da malha. O erro estrutural calculado pelo programa, embora mostrasse melhora com o aumento do número de elementos, não é válido devido ao uso de diferentes materiais na análise.

Uma das maneiras de avaliação da adequação da malha é a comparação entre os resultados nodais, que correspondem às médias das tensões dos elementos vizinhos em cada nó, e os resultados nos elementos, que 
correspondem às tensões no centróide de cada elemento. Esta foi a forma utilizada para calcular o erro estrutural.

Comparando três diferentes malhas, a primeira com um elemento ao longo da espessura das camadas interlaminares, a segunda com dois elementos ao longo da espessura das camadas interlaminares e a terceira com sete elementos ao longo da espessura das camadas interlaminares, notou-se pouca variação dos resultados. A malha com um elemento ao longo da espessura das camadas interlaminares apresentou um erro máximo de 2,9\%, a com dois elementos, 2,7\% e a com sete elementos, 1,7\%. Como a malha com sete elementos ao longo da espessura das camadas interlaminares deixou o modelo desnecessariamente grande, a segunda malha, com dois elementos ao longo da espessura foi aquele selecionado.

A malha gerada no pré-processamento da análise para elemento finito plano foi bastante refinada, contendo 26884 nós e 8799 elementos finitos, conforme mostra a Figura 29. As camadas de matriz polimérica pura (amarela) foram dividias em duas camadas de elementos finitos em suas espessuras. Já as camadas de fibra/ matriz (cor-de-laranja) foram divididas, tipicamente, em 5 camadas de elementos finitos em suas espessuras. 


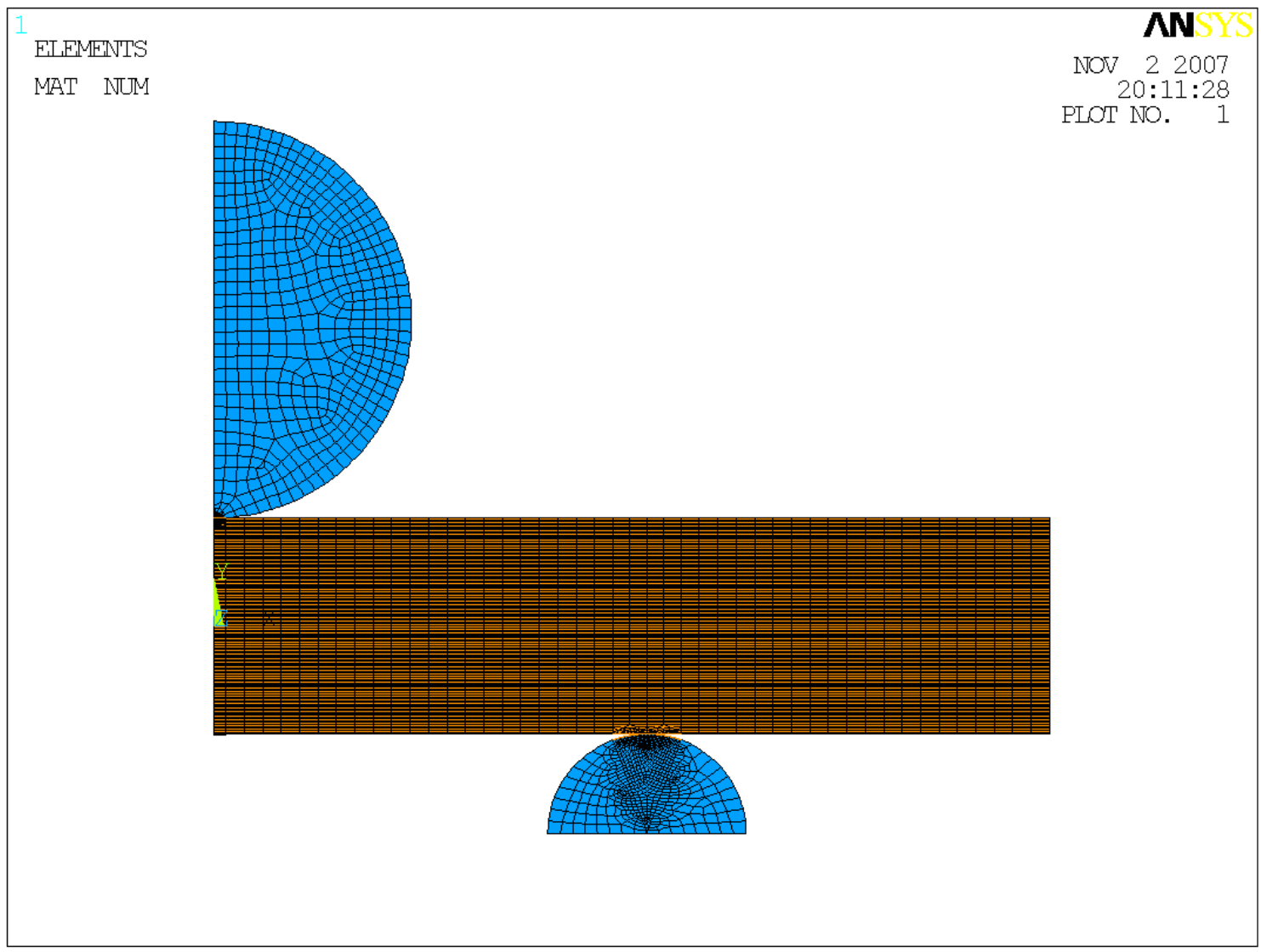

Figura 29: Malha de elementos finitos

As regiões de contato entre o corpo-de-prova e os cilindros são muito importantes já que nestas regiões ocorre uma alta variação do gradiente de tensões. Conseqüentemente, essas regiões tiveram suas malhas de elementos finitos mais refinadas. A Figura 30 ilustra a malha de elementos finitos utilizada na região do suporte. É importante lembrar que o contato entre o corpo-de-prova e os cilindros de suporte e carregamento foi representado por elementos finitos de contato CONTA172 e TARGE169, onde a superfície contato (CONTA172) corresponde à superfície de contato do cilindro e a superfície alvo, ou seja, a superfície deformante (TARGE169), corresponde à superfície de contato do corpo-de-prova. Os elementos finitos CONTA172 e TARGE169 são representados, na Figura 30 por linhas cor-de-laranja, muito sutis, nas superfícies de contato do corpo-de-prova e do cilindro de suporte. 


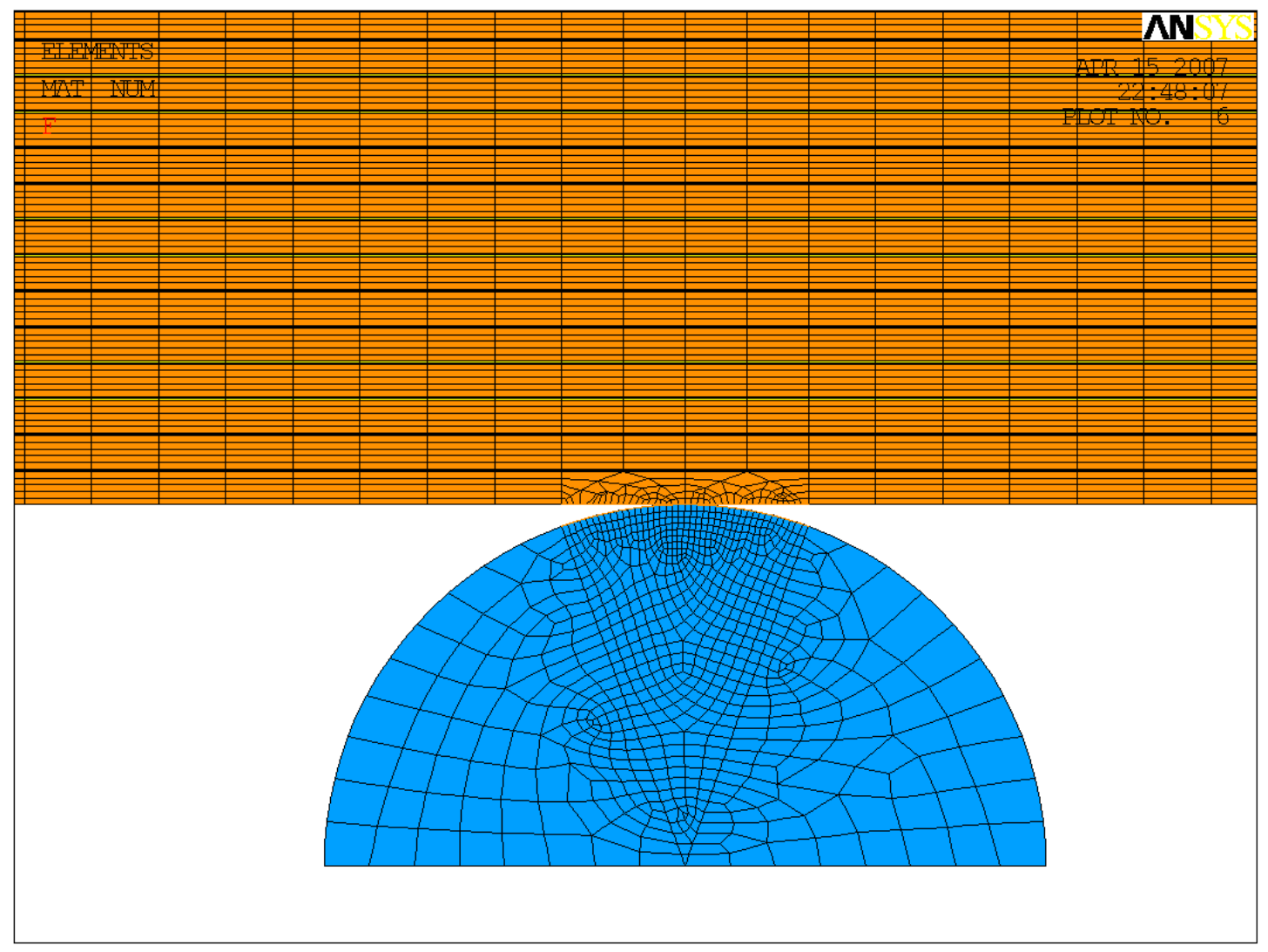

Figura 30: Malha de elementos finitos na região do suporte

O estudo de contato entre geometrias, distribuição de pressão, tensões e deformações de contatos cilíndricos é relativamente complexo. Derivações de equações destes casos estão entre os exemplos mais complexos da teoria da elasticidade. As equações para a área de contato, deformação, distribuição de pressão e tensões de contato entre dois corpos com carga estática foi originalmente derivada por Hertz em 1881. (NORTON, 1998)

A região de contato entre o cilindro de carga e a superfície do corpo-deprova foi refinada, na qual, dividiu-se em 20 elementos finitos uma largura calculada pela teoria de Hertz como a largura de contato (NORTON, 1998):

$$
a=\sqrt{\frac{2}{\pi} \frac{m_{1}+m_{2}}{B} \frac{F}{L}}=0,24 m m
$$

(Equação 5.9) 
Onde:

$\mathrm{m}_{1}=\left(1-v_{1}^{2}\right) / \mathrm{E}_{1}$, em $\mathrm{m}^{2} / \mathrm{N}$ (constante do material do corpo-de-prova)

$\mathrm{m}_{2}=\left(1-\mathrm{v}_{2}^{2}\right) / \mathrm{E}_{2}$, em $\mathrm{m}^{2} / \mathrm{N}$ (constante do material do cilindro de apoio)

Onde:

$$
\begin{aligned}
& E_{1}=10500 \mathrm{MPa} \\
& v_{1}=0,3 \\
& E_{2}=203400 \mathrm{MPa} \\
& v_{2}=0,3
\end{aligned}
$$

$\mathrm{F}=2178 \mathrm{~N}$, carga de falha, em N

$\mathrm{L}=6,5$, largura do corpo-de-prova, em $\mathrm{mm}$

$B=\frac{1}{2} \cdot \frac{1}{R}$; onde $\mathrm{R}$ é o raio do cilindro de carga, em $\mathrm{mm}$

Como o modelo é simétrico, a largura de contato no modelo será de a/2, ou seja, 0,12 mm. A Figura 31 ilustra a malha refinada nesta região de contato.

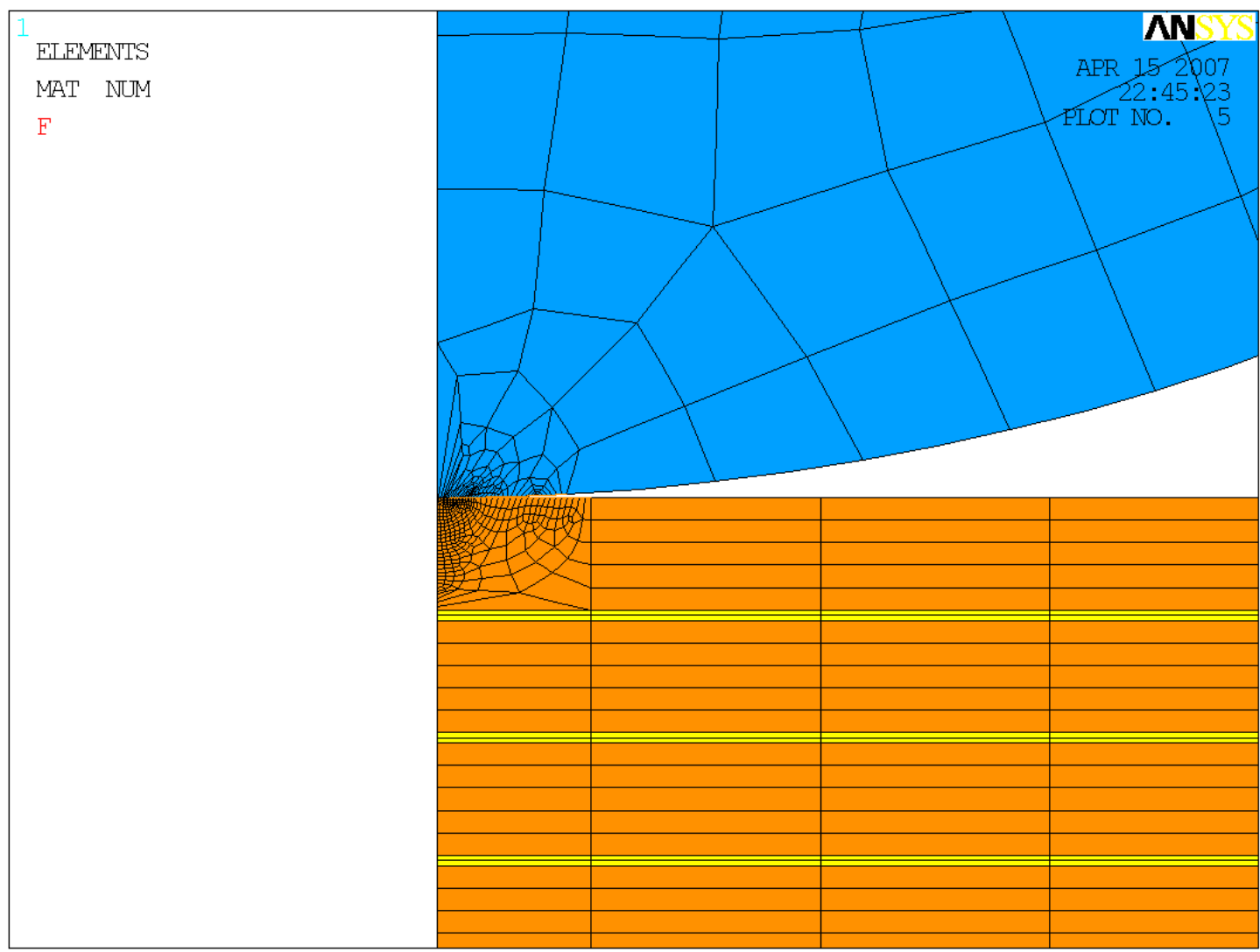

Figura 31: Malha refinada na região do contato 
$\mathrm{Na}$ Figura 31 se nota que a região de contato apresenta alguns elementos muito rígidos na transição da malha mais refinada para a malha mais grosseira. Esses elementos muito rígidos, que causam distorção nos resultados, seriam inaceitáveis para elementos lineares. No entanto, é importante lembrar, que o elemento PLANE183 tem 8 nós e um grau a mais na formulação (parabólica), permitindo resultados sem erro mesmo com malhas mais irregulares. Como pelo ensaio de ILSS observou-se que a falha se deu em uma das camadas centrais do laminado e não nas camadas superficiais, então é bem provável que a tensão concentrada na região de contato causa apenas uma falha extremamente localizada e pequena que não leva a falha global do laminado.

Na Figura 31 também estão representados os elementos finitos de contato. A superfície de contato do corpo-de-prova foi representada por elementos finitos alvo de contato TARGE169, enquanto a superfície de contato do cilindro de carregamento, por elementos finitos de contato CONTA172. Os elementos finitos CONTA172 e TARGE169 são representados, na Figura 30 por linhas cor-delaranja, muito sutis, nas superfícies de contato do corpo-de-prova e do cilindro de suporte.

\subsection{Resultados para o Modelo Plano}

A Figura 31.a ilustra o sistema de coordenadas tipicamente usado em um laminado multicamadas de comprimento L, largura 2.b e espessura 2.H. A origem do sistema de coordenadas localiza-se no centro do laminado, conforme ilustram as Figuras 31.a e 31.b. $O$ eixo $X$ é paralelo ao comprimento $L$ do laminado, o eixo $\mathrm{Y}$ é paralelo à largura 2.b do laminado e o eixo $\mathrm{Z}$ é paralelo à espessura $2 . \mathrm{H}$ do laminado. A orientação das tensões e deslocamentos de um laminado pode ser compreendida a partir do diagrama de corpo livre apresentado na Figura 32.c. Se comparado ao diagrama do corpo livre , o plano xy do modelo plano de elementos finitos do presente estudo corresponde ao plano $x z$, paralelo ao comprimento $L$ representado Figura 32.a. Conseqüentemente, as tensões cisalhantes de interesse serão as $\tau_{x y}$, referenciadas nos resultados da análise de tensões por Sxy. 


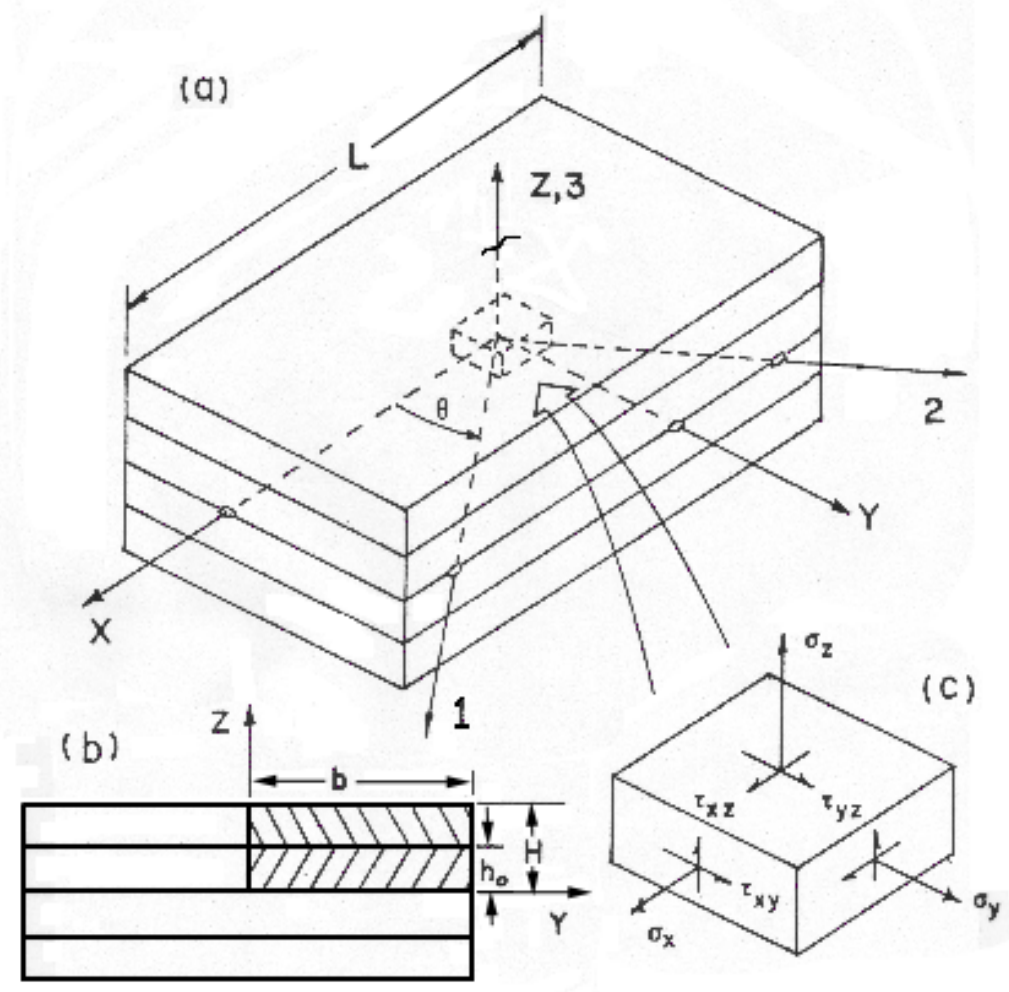

Figura 32: (a)Sistema de coordenadas do laminado; (b) Seção transversal do laminado e; (c) Diagrama de corpo livre do laminado

O programa ANSYS tem uma interface gráfica na qual é possível visualizar diferentes comandos entrados pelo usuário. A visualização desses comandos, em forma gráfica, é tipicamente denominada por usuários de programas de análise por elementos finitos de "plotagem"; termo originado da palavra em inglês plot. Doravante, o termo "plotagem" será utilizado para referir-se a esses gráficos. Existem plotagens disponíveis apenas na fase de pré-processamento, como a visualização da geometria do modelo, das condições de contorno, da malha de elementos, entre outros. Já na fase de pós-processamento, é possível geral plotagens dos resultados da análise, como tensões resultantes, deslocamentos, forças de reação, entre outros.

Primeiramente, foi tirada a plotagem com os deslocamentos verticais (na direção y do modelo plano de elementos finitos). A Figura 33 mostra os resultados. Nota-se que a região central do corpo-de-prova, onde a força é aplicada, existe uma deflexão de 0,19 $\mathrm{mm}$ verticalmente para baixo, enquanto 
que, nas extremidades do corpo-de-prova, há uma pequena deflexão para cima de $0,029 \mathrm{~mm}$, como efeito da flexão do corpo-de-prova.

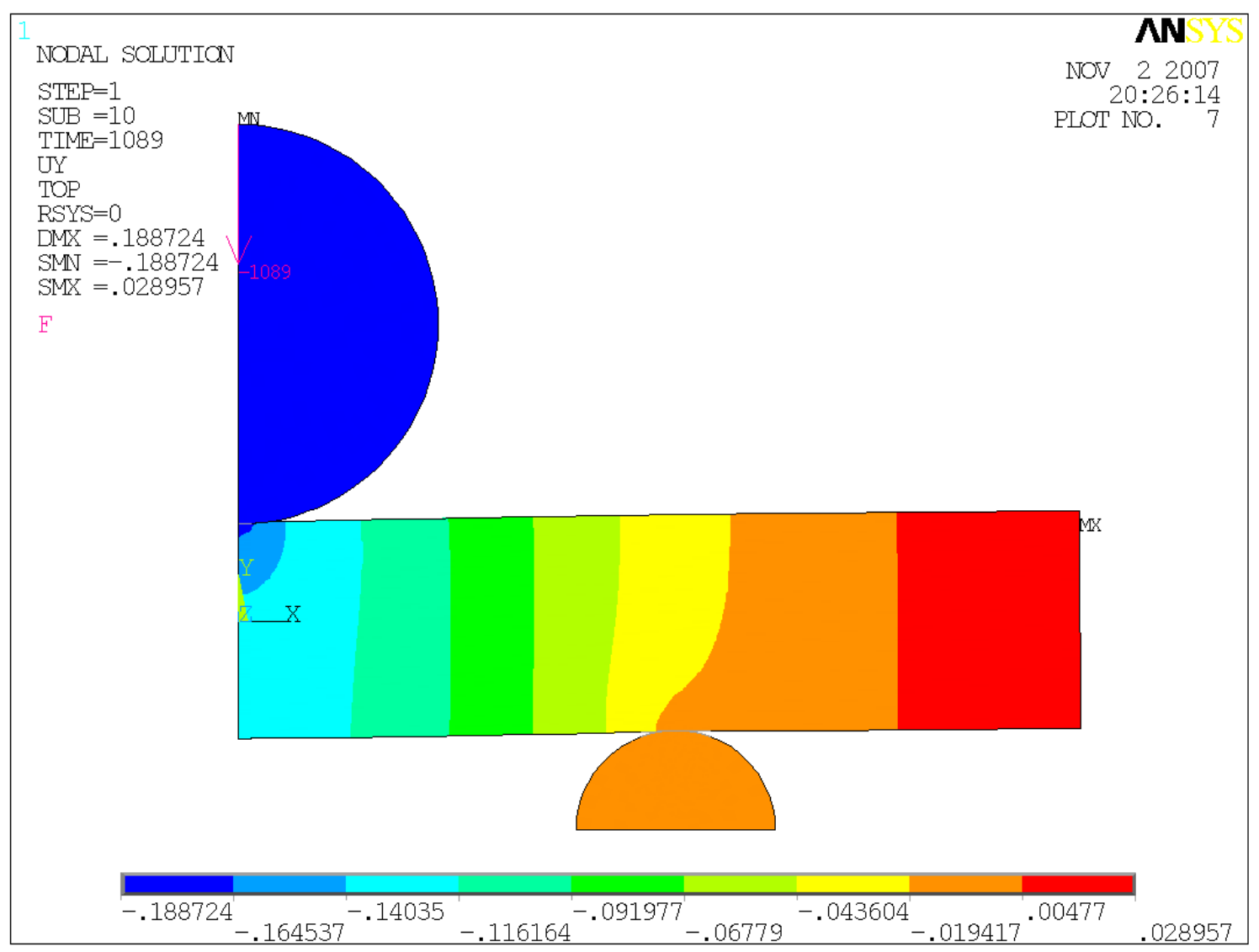

Figura 33: Deslocamentos em y

Em seguida, foram tiradas as plotagens com as tensões de cisalhamento Sxy. Para uma melhor visualização dessas tensões de cisalhamento, foram feitas linearizações de tensões em diferentes seções do modelo ao longo da espessura e ao longo do comprimento, conforme mostra a Figura 34.

A linearização de tensões é o nome dado a uma ferramenta bastante útil do programa ANSYS de elementos finitos para visualização dos resultados nodais de modelos que usam elementos finitos sólidos. Isso porque, em elementos finitos sólidos, é possível visualizar a distribuição de tensões e de deformações, mas é difícil visualizar a variação e as tensões e deformações média e de flexão. Através da linearização de tensões, o usuário do programa pode selecionar um "caminho" de nós no modelo no qual o programa ANSYS fornece um gráfico que representa 
os valores de tensão ou de deformação em função da distância ao longo deste "caminho". Desta maneira, os valores de tensão ou de deformação naquela seção selecionada ficam claramente ilustrados no gráfico. No gráfico fornecido pela linearização de tensões, três curvas de tensões ou deformação são ilustradas ao longo do "caminho". A curva vermelha representa as tensões totais ao longo do "caminho" selecionado, a curva azul representa a tensão média ao longo do "caminho" e a curva roxa representa as tensões média mais flexão ao longo do "caminho". Na presente análise por elementos finitos planos, as tensões resultantes de interesse são àquelas de cisalhamento total, representadas pela curva vermelha nos gráficos adiante.

A linearização ao longo do comprimento, denominada LONGMID foi feita justamente na camada do meio, de matriz polimérica, para melhor ilustrar a distribuição da tensão cisalhante na direção longitudinal do corpo-de-prova. Nas linearizações através da espessura, é importante notar que as seções selecionadas, denominadas de TRANSV1, TRANSV2 e BORDA estão distantes das regiões de perturbação, ou seja, de tensões extremamente concentradas, que correspondem aos pontos de contato entre o corpo-de-prova e os cilindros de carga e suporte. 


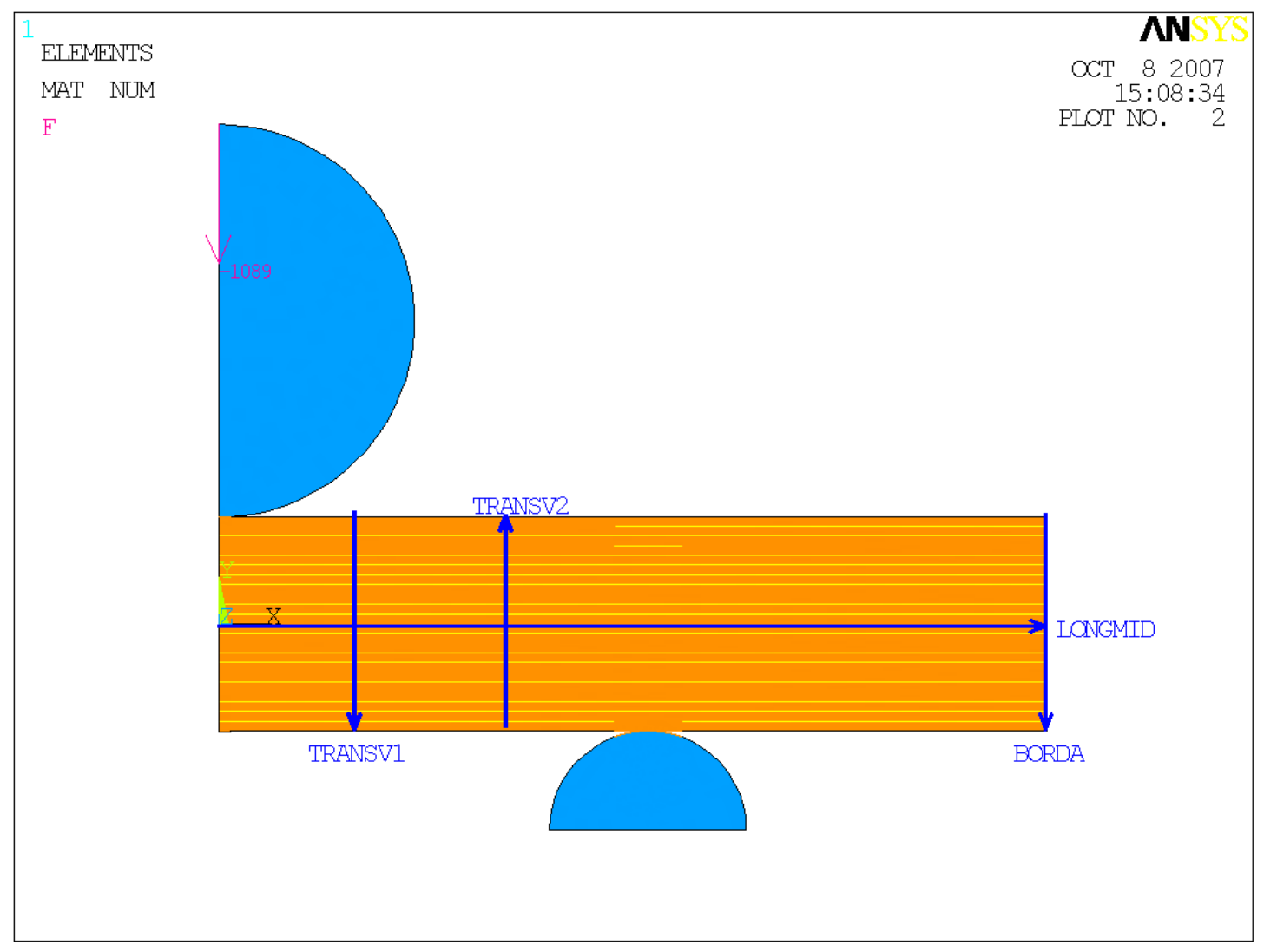

Figura 34: Caminhos das linearizações de tensões

A partir do gráfico de distribuição de tensões cisalhantes do caminho "LONGMID", determinou-se ao longo do comprimento, qual a seção transversal no corpo-de-prova na qual a tensão cisalhante é máxima. A partir desse dado ( $\mid$ = 4,05 mm) foi selecionada a seção "TRANSV2" para ser feita linearização.

A distribuição das tensões de cisalhamento em todo o modelo é mostrada adiante na Figura 35. 


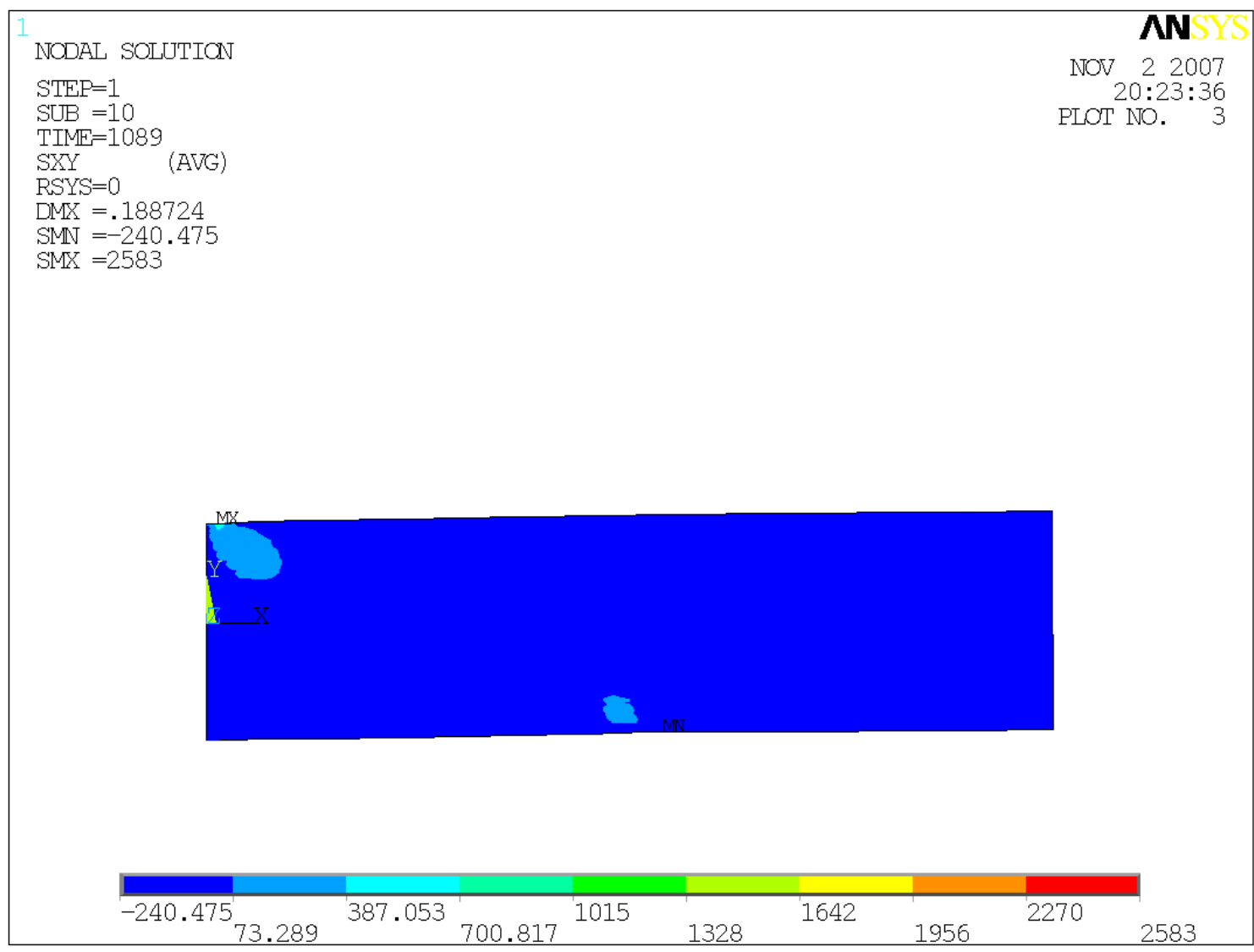

Figura 35: Distribuição da tensão de cisalhamento, em MPa

$\mathrm{Na}$ Figura 35, o símbolo $\mathrm{MX}$ corresponde ao ponto de tensão de cisalhamento máxima, e o símbolo $\mathrm{MN}$ corresponde ao ponto de tensão de cisalhamento mínima.

Nota-se pela Figura 35 que as regiões do cilindro de apoio e o ponto de aplicação da carga apresentam tensões de cisalhamento extremamente concentradas, que prejudicam a visualização da distribuição de tensões de cisalhamento ao longo da espessura do corpo-de-prova. Como essas tensões são extremamente altas, chegando a $2583 \mathrm{MPa}$ no ponto de aplicação da carga de compressão, não é possível verificar a faixa de variação de tensões na região fora da perturbação. Para contornar esse problema, as camadas superiores e inferiores do modelo foram excluídas na plotagem da distribuição de tensões de cisalhamento, resultando na seguinte plotagem da Figura 36: 


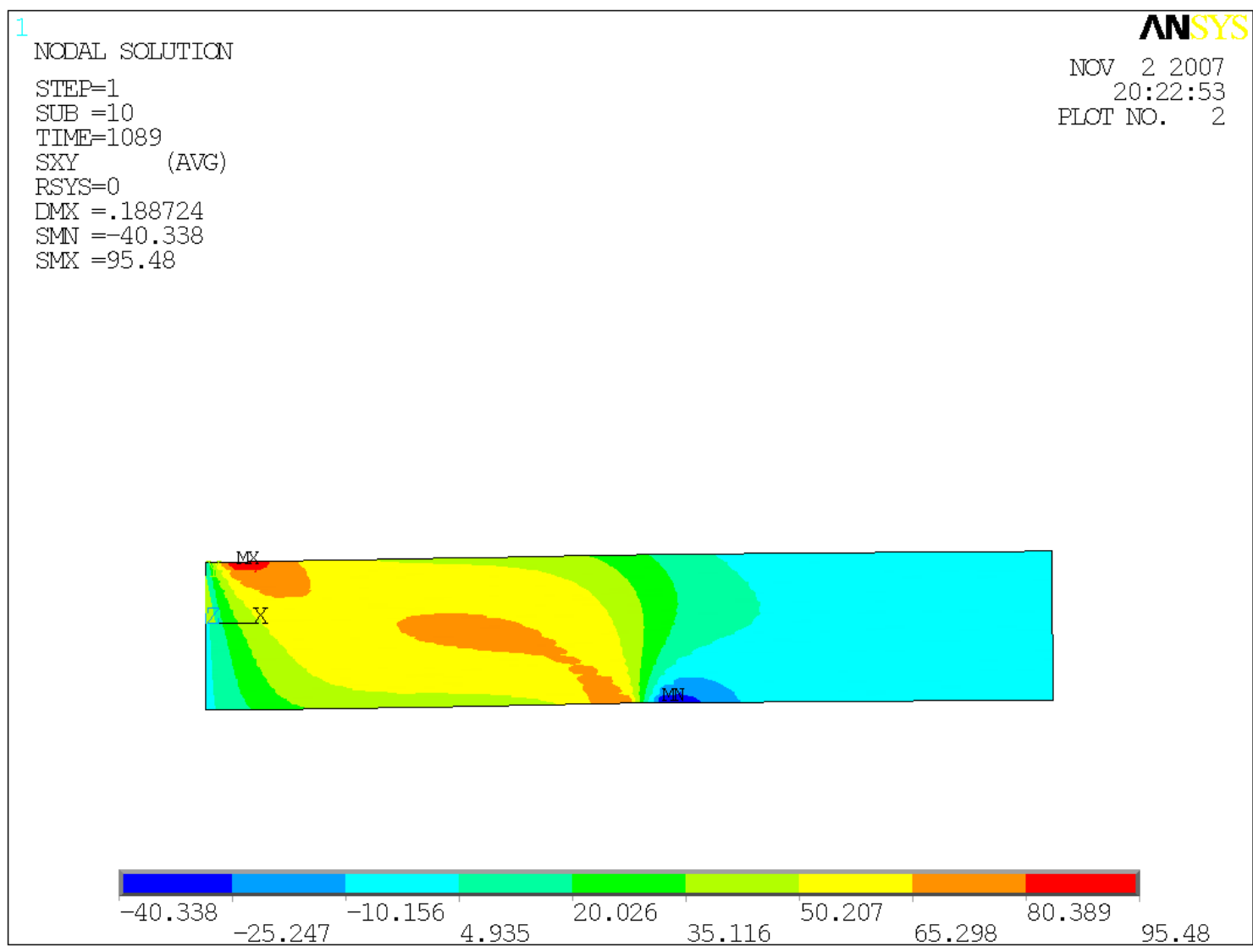

Figura 36: Distribuição da tensão de cisalhamento nas 15 camadas centrais, em $\mathrm{MPa}$

Na Figura 36 a visualização da distribuição de tensões de cisalhamento ao longo da espessura fica bem mais clara, uma vez que as camadas em contato com os cilindros são eliminadas da plotagem.

Nota-se uma tensão de cisalhamento máxima de $95,5 \mathrm{MPa}$ no ponto de aplicação da carga e uma tensão de $-40,3 \mathrm{MPa}$. A diferença de sinais significa que os cisalhamentos nessas camadas ocorrem em sentidos opostos.

Doravante, as tensões resultantes serão exibidas apenas para as 15 camadas centrais do corpo-de-prova por ser uma região livre de perturbações, estas localizadas na região de aplicação da força e o apoio do corpo-de-prova.

A Figura 37 mostra as tensões de cisalhamento através da espessura nos elementos finitos que representam as regiões das 15 camadas centrais 
compostas de fibra de carbono + matriz. Nota-se que a tensão máxima $(95,5$ $\mathrm{MPa}$ ) ocorre justamente em uma das regiões compostas de fibra + matriz.

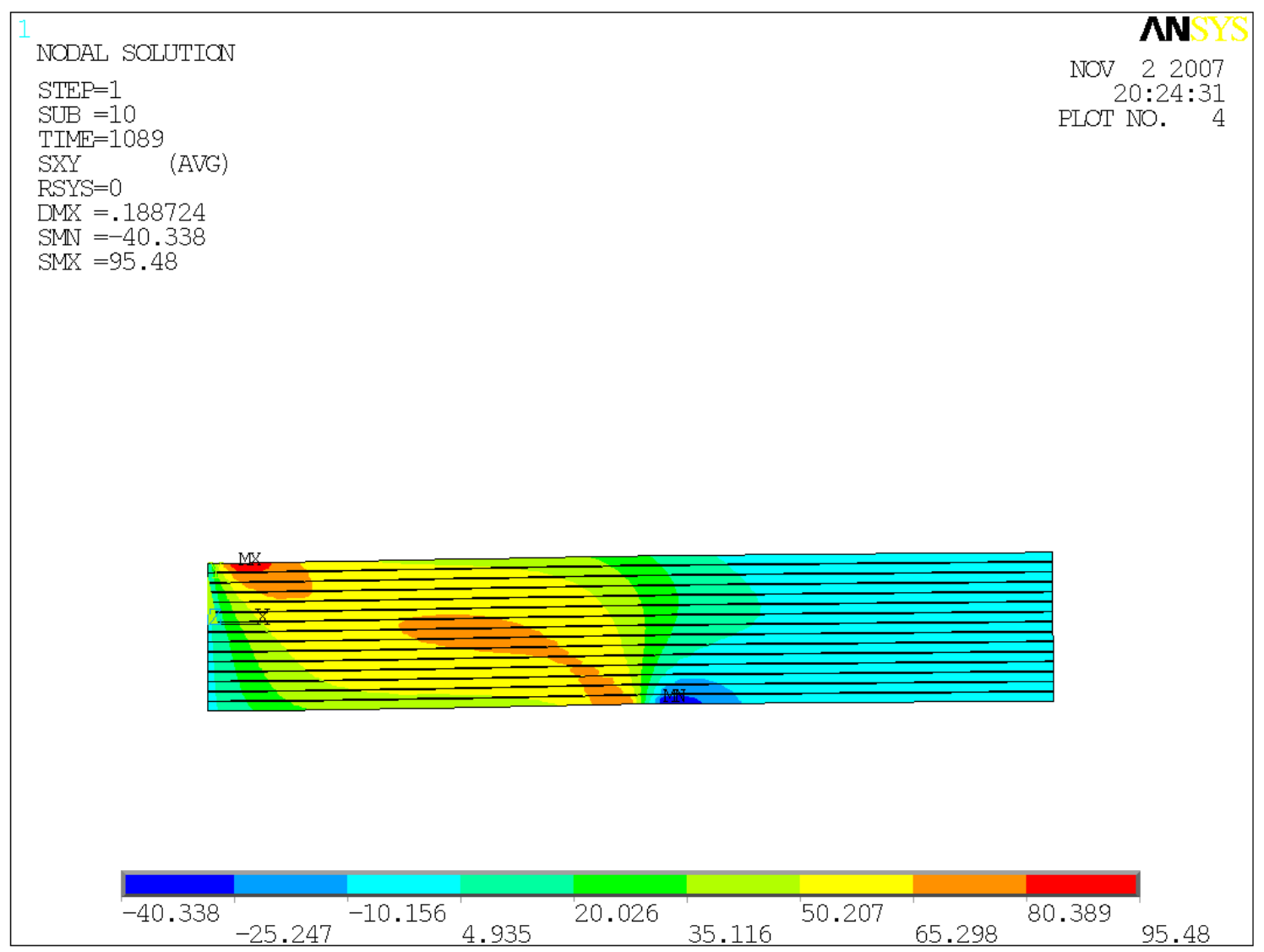

Figura 37: Tensões de cisalhamento nos elementos finitos compostos de fibra de carbono + matriz, em MPa (apenas as 15 camadas centrais do corpo-de-prova)

A Figura 38 mostra as tensões de cisalhamento através da espessura nos elementos finitos que representam as regiões das 15 camadas centrais compostas de matriz polimérica apenas. A tensão de cisalhamento máxima encontrada é de 80,7 MPa. 


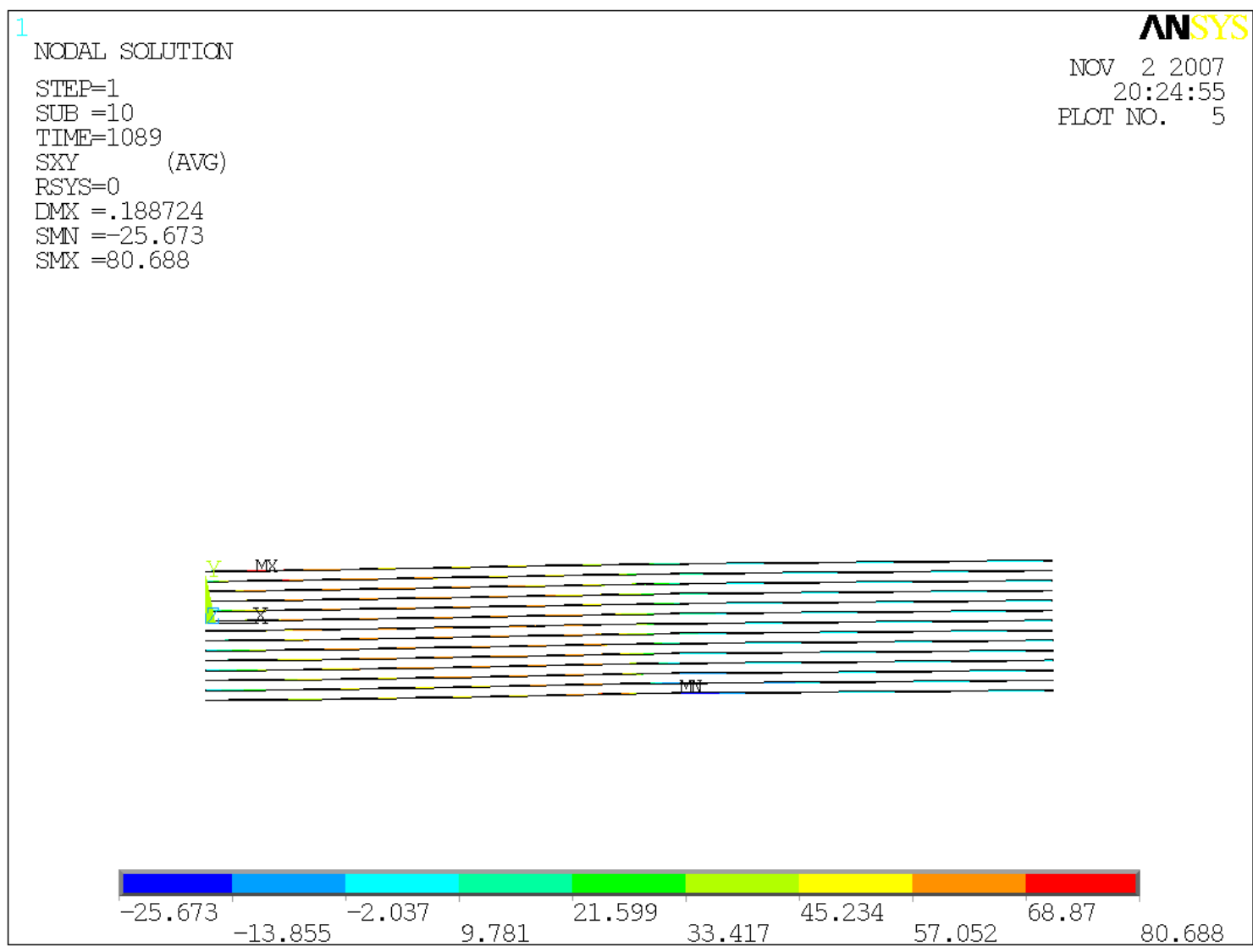

Figura 38: Tensões de cisalhamento nos elementos finitos compostos de matriz pura, em MPa (apenas as 15 camadas centrais do corpo-de-prova)

Conforme ilustrado na Figura 34, algumas seções ao longo do modelo foram selecionadas para que fossem feitas linearizações de tensões. Para estudar a distribuição de tensão de cisalhamento ao longo do comprimento, foi feita a linearização pelo caminho "LONGMID", mostrado na Figura 39. 


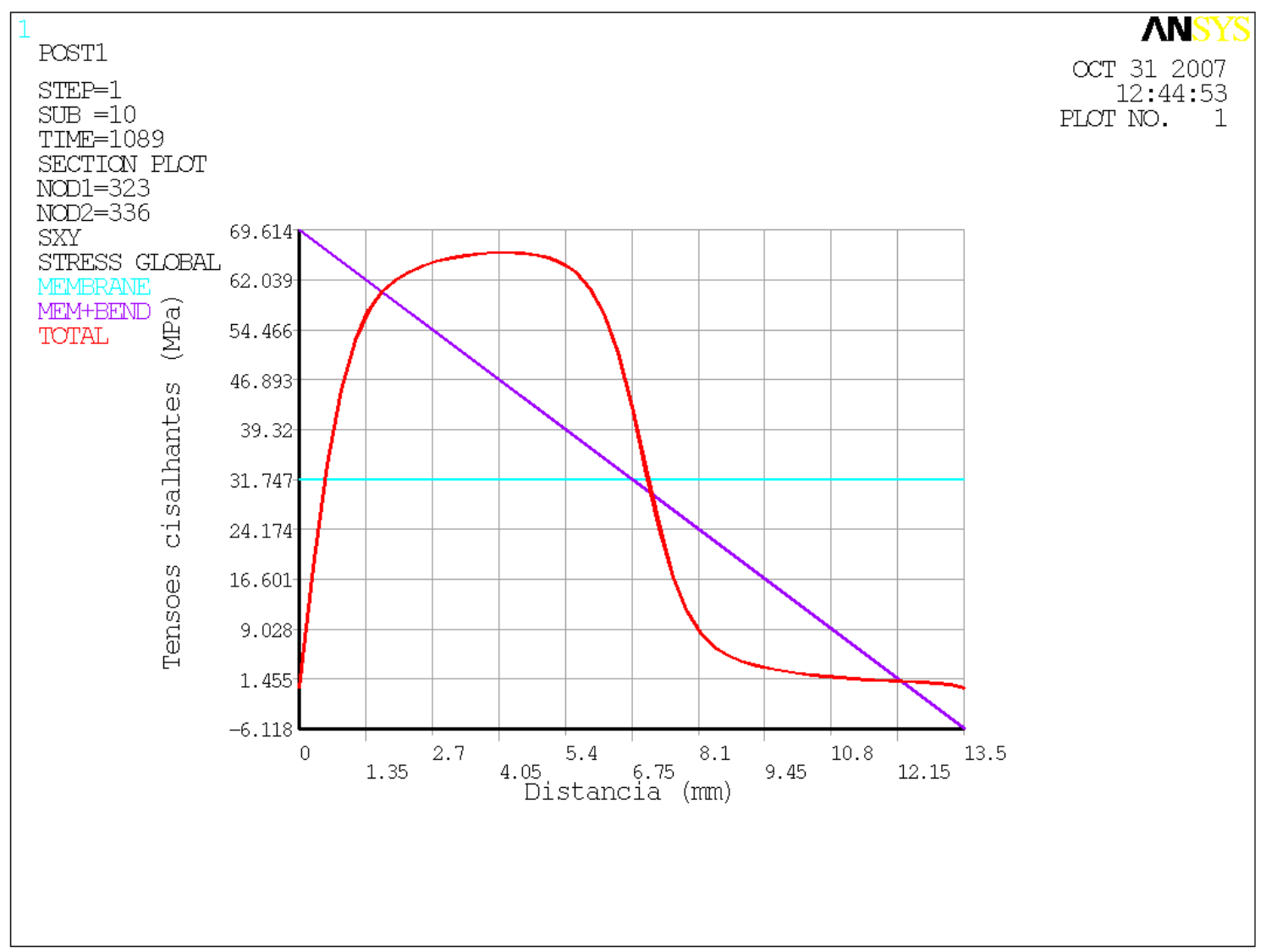

Figura 39: tensões cisalhantes na seção "LONGMID"

Nota-se que a curva de tensão cisalhante total não apresenta descontinuidades nas suas diferentes inclinações, o que significa que a malha escolhida foi adequada para captar a variação de tensões corretamente. Essa característica repete-se nos próximos dois gráficos. Apenas não ocorre na linearização da "BORDA" por ser uma região de grande variação de tensões, o que já era esperado.

A tensão cisalhante xy máxima na camada interlaminar média do corpo-deprova é de 69,6 MPa.

A partir deste gráfico de linearização de tensões no comprimento e a partir da plotagem da Figura 36, nota-se que o campo de tensão cisalhante máxima encontra-se entre a aplicação da força e o apoio. Justamente por este motivo, foram selecionadas as seções "TRANSV1" e "TRANSV2" para serem analisadas com mais atenção quanto às tensões de cisalhamento. 
A seção "TRANSV1" está a uma distância horizontal de $2,3 \mathrm{~mm}$ do centro do corpo-de-prova, e a seção "TRANV2" está a uma distância horizontal de 4,7 $\mathrm{mm}$ do centro do corpo-de-prova.

A seção "BORDA" foi selecionada como caminho de linearização de tensões, apesar de apresentar tensões cisalhantes muito baixas, porque depois de feito o teste ILSS, as extremidades do corpo-de-prova são justamente as regiões em que ocorre a delaminação entre camadas, conforme nota-se na Figura 40 .

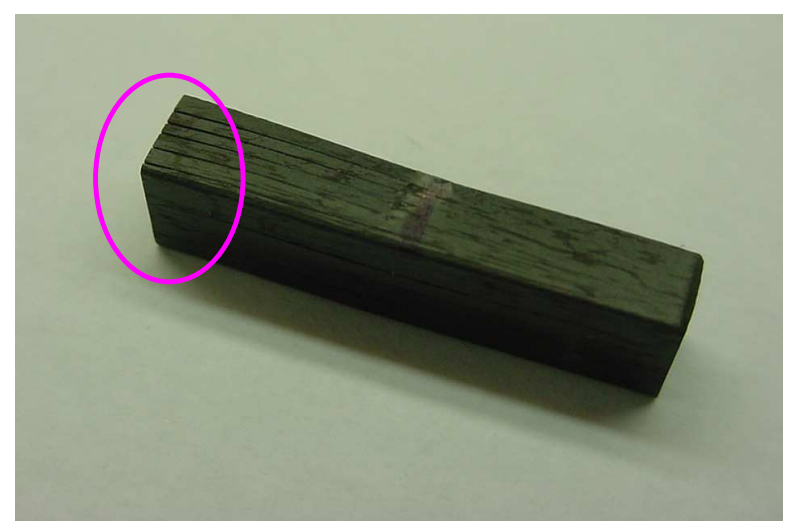

Figura 40: corpo-de-prova após falha por ILSS (foto macro)

A Figura 41 mostra a abertura das trincas no corpo-de-prova após a falha por ILSS com um aumento de 40 vezes.
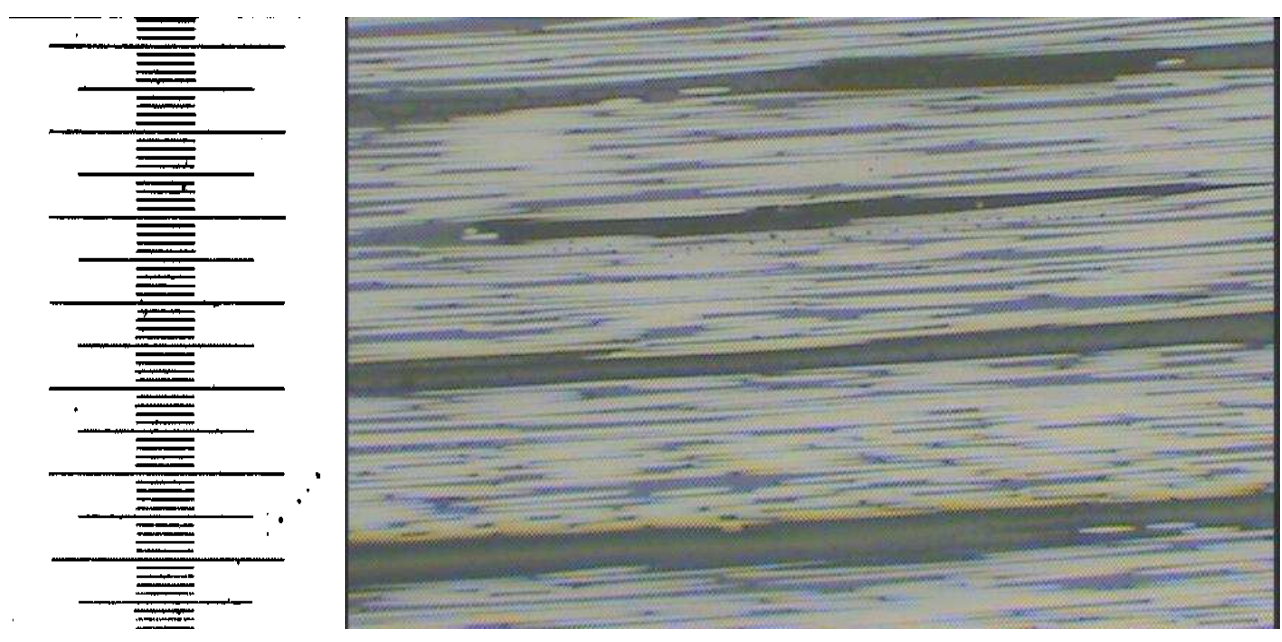
Figura 41: corpo-de-prova após falha por ILSS (aumento 40x)

A distribuição de tensões de cisalhamento ao longo da espessura pelos caminhos "TRANSV1", "TRANSV2" e "borda" são ilustrados na Figura 42 e Figura 43.

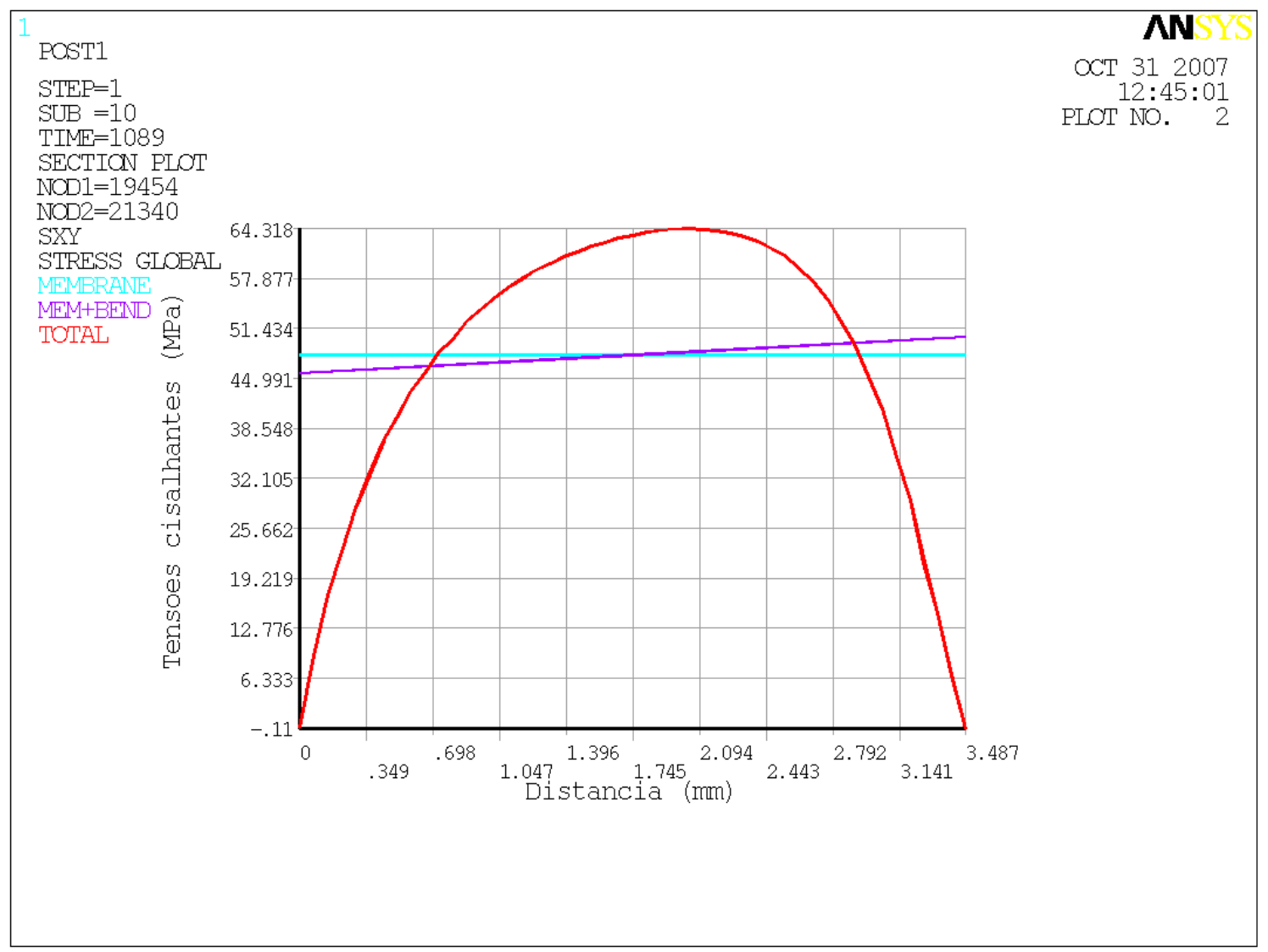

Figura 42: tensões cisalhantes na seção "TRANSV1"

No gráfico da Figura 41, o eixo x corresponde à distância, através da espessura, onde zero é a face inferior do corpo-de-prova. O eixo y corresponde ao valor das tensões cisalhantes, em MPa. A curva "TOTAL" é a tensão cisalhante propriamente dita. A curva "MEMBRANE" corresponde à tensão de cisalhamento média na seção; e a curva "MEM+BEND" corresponde à tensão de cisalhamento média somada à tensão de cisalhamento de flexão. Desta maneira, a curva "MEMBRANE" é reta é constante; a curva "MEMB+BEND" é reta; e a 
curva "TOTAL", pode ter um formato qualquer por incluir todos os efeitos mecânicos e geométricos.

A curva "TOTAL" é aquela de interesse ao estudo. Na seção "TRANSV1", a tensão de cisalhamento máxima encontrada foi de $64,3 \mathrm{MPa}$.

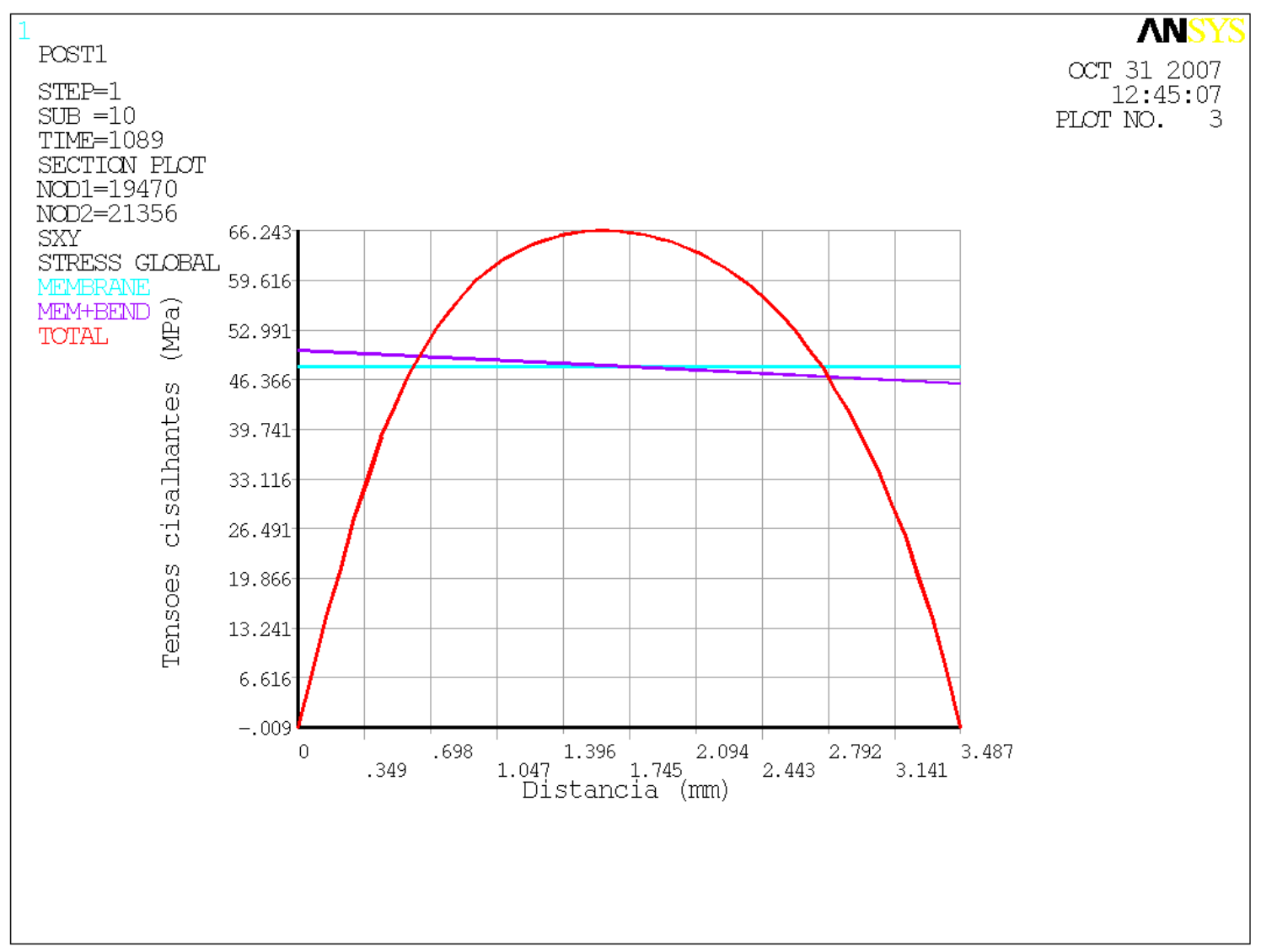

Figura 43: tensões cisalhantes na seção "TRANSV2"

No gráfico acima, o eixo x corresponde à distância, através da espessura, onde zero é a face inferior do corpo-de-prova. O eixo y corresponde ao valor das tensões cisalhantes, em MPa. A curva "MEMBRANE" corresponde à tensão de cisalhamento média; a curva "MEM+BEND" corresponde à tensão de cisalhamento média somada à tensão de cisalhamento de flexão; e a curva "TOTAL" corresponde à tensão de cisalhamento total. Na seção "TRANSV2", a tensão de cisalhamento máxima encontrada foi de 66,2 MPa. 


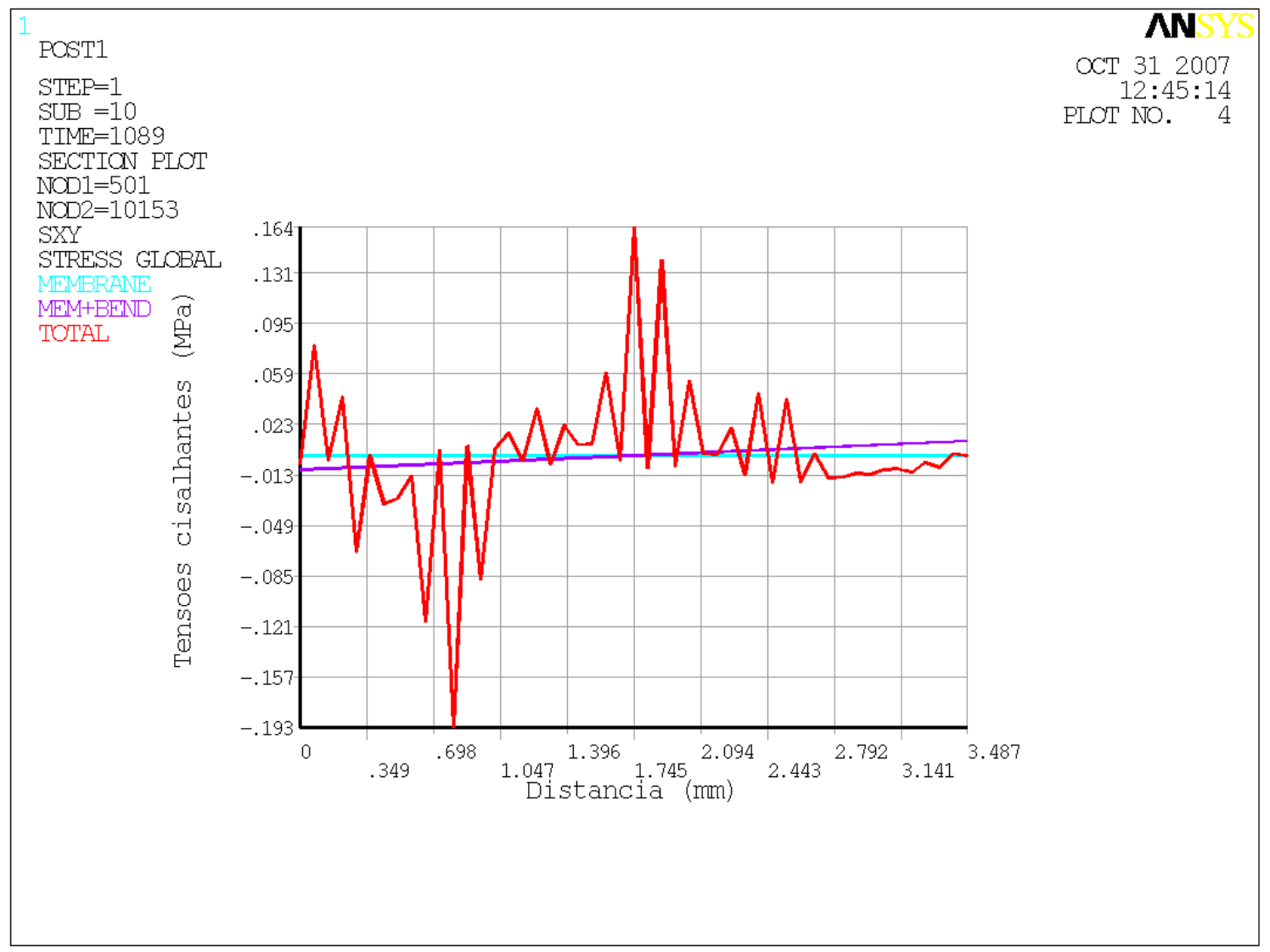

Figura 44: tensões cisalhantes na seção "BORDA"

Apesar de apresentarem valores máximos de tensão cisalhante bem próximos do valor do teste de $72 \mathrm{MPa}$, pouco se nota a diferença nas tensões cisalhantes nas regiões entre camadas (epóxi puro) nos gráficos de linearização de tensões cisalhantes xy na Figura 42 e Figura 43. No entanto, na linearização da borda do corpo-de-prova, a diferença entre as tensões nas regiões com fibra e nas regiões com matriz pura é bem clara.

A linearização da seção "BORDA" ilustra muito bem o efeito da delaminação, conforme mostra a Figura 44. Justamente por apresentar grandes deformações, essa seção apresenta tensões cisalhantes baixas, É interessante notar na Figura 44 que o número de picos no gráfico é o mesmo número de camadas do corpo-de-prova (22 camadas). Os picos correspondem às tensões nas camadas carbono/ epóxi, e os vales, às tensões nas camadas interlaminares de matriz polimérica. 


\subsection{Modelo Tridimensional (Layered Shell Element)}

Dois pontos motivaram a escolha do elemento finito de casca em camadas (layered) como uma segunda opção de estudo.

O primeiro motivo é a simplicidade do elemento. O elemento finito de casca exige menos tempo e custo de processamento e permite modelos bem mais simples do que aqueles sólidos. Ao representar um equipamento grande, o elemento finito de casca levaria muito menos tempo de modelagem e de processamento.

Um segundo motivo é o eventual fenômeno de tridimensionalidade do corpo-de-prova, ou seja, o não estado plano de tensões. Trabalhos teóricos de Kedward previram uma variação das tensões cisalhantes através da largura do material, com picos nas bordas da chapa de teste (KEDWARD, 1972). Isso significa que os corpos de prova são, na verdade, tridimensionais, com tensões variando através do corpo-de-prova do tipo viga. Logo, o estado plano de tensões não pode ser interpretado adequadamente por meios da teoria de viga clássica.

O modelo tridimensional representa o corpo-de-prova de compósito carbono/ epóxi com elemento finito de casca em camadas (layered) "SHELL 99". O pino de suporte, com propriedades do aço carbono, foi representado com elementos finitos sólidos tridimensionais "SOLID45". Entre o corpo-de-prova e o pino de suporte, foram acrescentados elementos finitos de contato "TARGET169" e "CONTA175".

Um maior detalhamento desses elementos finitos será feito a seguir:

SHELL99: Este elemento é usado para modelos de casca estruturais compostos de várias camadas. O elemento finito SHELL99 tem 6 graus de liberdade em cada nó: translações do nó em x, y e z e rotação do nó nos eixos $x$, y e z. A Figura 45 ilustra os elementos finitos quadrático e triangular e o sistema de coordenadas que orienta o elemento finito no programa ANSYS: (ANSYS TUTORIAL, 2006) 


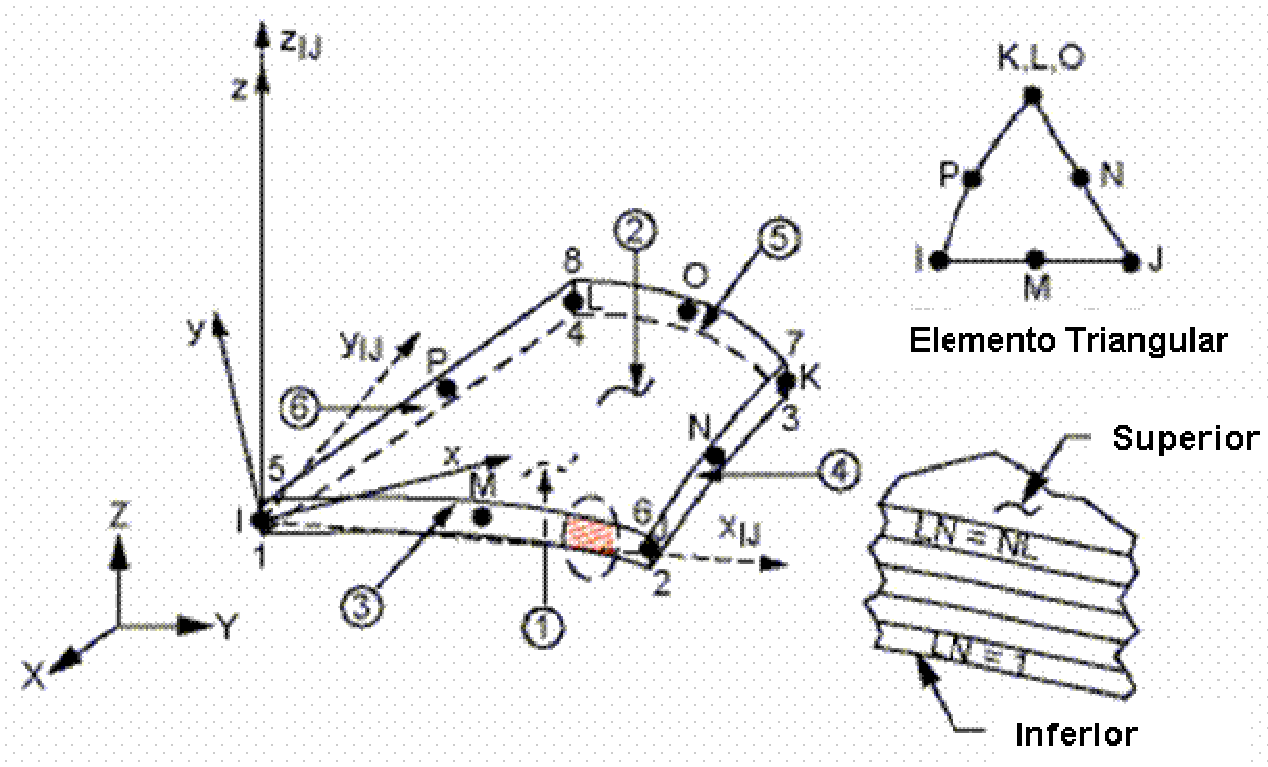

Figura 45: Elemento finito de casca multicamadas SHELL99

Na Figura 45 tem-se:

Sistema de coordenadas à esquerda = sistema de coordenadas global (diferente daquele do elemento)

$\mathrm{x}_{\mathrm{IJ}}=$ eixo $\mathrm{x}$ do elemento, caso o sistema de coordenadas não seja

informado pelo usuário

$\mathrm{x}=$ eixo $\mathrm{x}$ do elemento, caso o sistema de coordenadas seja informada

pelo usuário

$\mathrm{LN}=$ Número da camada

$\mathrm{NL}=$ Número total de camadas

O elemento finito SHELL99 é definido por 8 nós, espessura das camadas, material da camada e ângulo das fibras, e propriedades ortotrópicas do material. O elemento pode ser de formato quadrático ou triangular.

$\mathrm{Na}$ versão do programa ANSYS utilizada para o presente estudo, um número máximo NL de 20 camadas é permitido, ou seja, $\mathrm{LN}$ pode variar de 1 a 20. No sistema de coordenadas local do elemento, o ângulo de orientação da fibra em cada uma das $L N$ rotaciona positivamente do eixo x para o eixo y. $O$ número 
total de camadas deve ser especificado. As propriedades de todas as camadas devem ser fornecidas.

O programa permite que o usuário selecione o critério de falha. O programa oferece como opções o critério de falha por deformação máxima, por tensão máxima, o critério de falha de Tsai-Hill ou algum outro critério de falha que o usuário deseje.

SOLID45: Este elemento finito é usado para modelos tridimensionais de estruturas sólidas. O elemento finito SOLID45 é definido por 8 nós com 3 graus de liberdade em cada um deles: translações do nó em x, y e z. O elemento permite plasticidade, fluência, grandes deformações e grandes deslocamentos. A Figura 46 ilustra os elementos finitos quadrático, prismático e tetraédrico e o sistema de coordenadas que orienta o elemento finito no programa ANSYS: (ANSYS TUTORIAL, 2006)

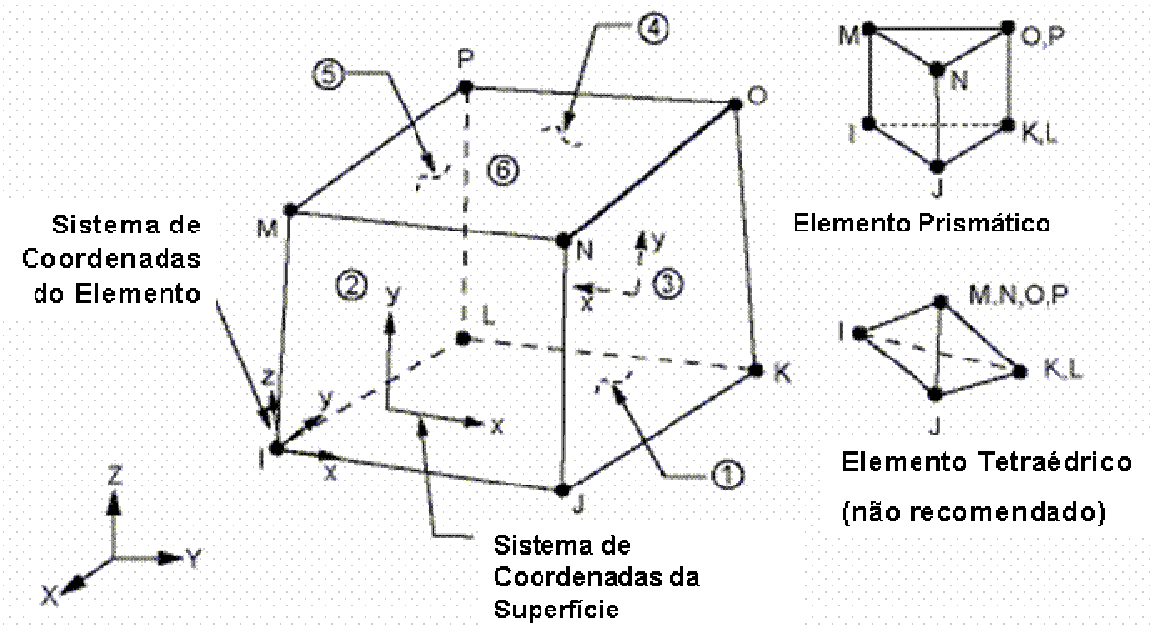

Figura 46: Elemento finito sólido tridimensional SOLID45

CONTA175: Esse elemento finito é usado para representar a superfície de contato entre duas superfícies. No modelo do presente estudo, o elemento finito CONTA175 corresponde à região de contato dos cilindros de carga e suporte. Este elemento é aplicável em estruturas de ou duas ou três dimensões. A Figura 47 ilustra os elementos finitos quadrático e triangular e o sistema de coordenadas que orienta o elemento finito no programa ANSYS: 


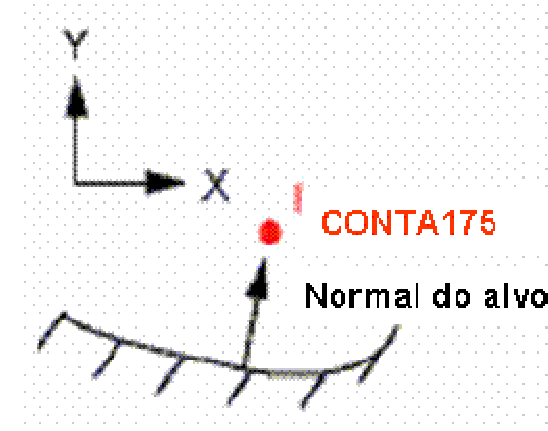

Superfície alvo associada bidimensional (TARGET169)

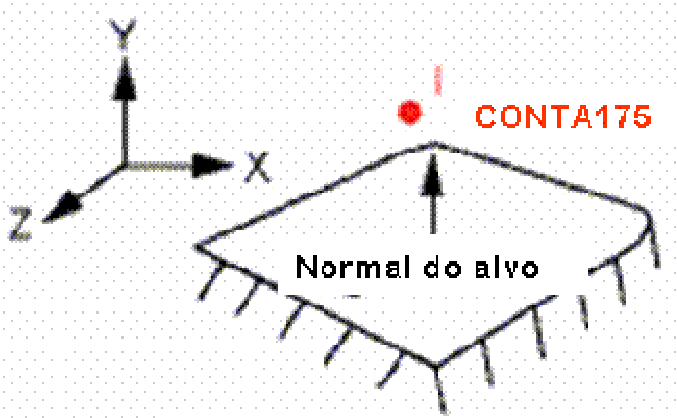

Superfície alvo associada tridimensional (TARGET170)

Figura 47: elemento finito de contato CONTA175

As principais direções são computadas na superfície alvo e, então, projetadas no nó do elemento finito de contato. A primeira direção principal é definida pela projeção da primeira direção do sistema de coordenada escolhido sobre a superfície alvo. A segunda direção principal é definida tomando-se um produto vetorial da primeira direção principal e a norma do alvo. Essas direções também permitem rotações de corpo rígido do elemento finito de contato para modelar de maneira correta a dependência direcional do atrito. É necessário que haja uma escolha cuidadosa do sistema (global ou local) de coordenada de maneira que a primeira direção deste sistema esteja dentro de $45^{\circ}$ da tangente da superfície de contato. O elemento finito CONTA175 está associado com o elemento finito de contato alvo TARGE169 por meio de um mesmo conjunto de constantes reais. Constantes reais correspondem a entradas de dados do programa que caracterizam os elementos finitos, como espessura, momento de inércia, propriedades em geral. (ANSYS TUTORIAL, 2006)

TARGET169: Já definido no item 5.7.

O modelo utilizado para esta análise apresenta orientação diferente do modelo da análise plana anterior. Se comparado ao modelo de diagrama de corpo livre da Figura 32, o modelo de elementos finitos de casca do presente estudo tem seu comprimento paralelo ao eixo $\mathrm{x}$, sua largura paralela ao eixo y e sua 
espessura paralela ao eixo z. Conseqüentemente, as tensões cisalhantes de interesse serão as $\tau_{\mathrm{xz}}$, referenciadas nos resultados da análise de tensões por Sxz.

Como o programa permite apenas que se divida o elemento em no máximo 20 camadas, e o corpo-de-prova possui 44 camadas (22 com 0,146 de espessura com as propriedades carbono/ epóxi e $22 \mathrm{com} \mathrm{0,01326} \mathrm{mm} \mathrm{de} \mathrm{espessura} \mathrm{com} \mathrm{as}$ propriedades da matriz polimérica), então, foi feita uma aproximação na modelagem. Dentre as 22, as 6 camadas inferiores foram representadas por uma única de $1,10038 \mathrm{~mm}$ de espessura aproximadamente com as propriedades carbono/ epóxi. As 8 camadas seguintes, na região central do compósito, foram modeladas com o detalhamento de 0,146 de espessura com as propriedades carbono/ epóxi e 0,01326 $\mathrm{mm}$ de espessura com as propriedades da matriz polimérica. $\mathrm{E}$, finalmente, as 7 camadas superiores foram representadas por uma única de $1,113 \mathrm{~mm}$ de espessura aproximadamente com as propriedades carbono/ epóxi. Essa aproximação foi feita justamente porque a região central do compósito é aquela distante as regiões de perturbação (contato entre pinos de carga e de suporte) e onde a análise anterior mostrou valores de tensão cisalhante mais próximos do experimental.

É muito importante que a camada superior e camada inferior tenham propriedades mecânicas do carbono + epóxi, uma vez que são regiões em contato com o pino de carregamento e pinos de contato. Por este motivo, existe uma pequena diferença entre as espessuras das camadas superior e inferior; a distribuição das camadas foi feita justamente de maneira que os elementos de contato com os pinos fossem elementos com propriedades diferentes das do epóxi puro.

A Tabela 5 ilustra melhor a distribuição de camadas utilizada no modelo de elementos finitos de casca (a numeração das camadas 1 a 19 é de baixo para cima). 
Tabela 5: Camadas do elemento finito de casca

\begin{tabular}{|c|c|c|}
\hline $\begin{array}{c}\text { Camada N } \\
\text { Layr N }^{\circ}\end{array}$ & $\begin{array}{c}\text { Espessura } \\
{[\mathrm{mm}]}\end{array}$ & Material \\
\hline 1 & 1.11364 & carbono/ epóxi \\
\hline 2 & 0.01326 & epóxi \\
\hline 3 & 0.14583 & carbono/ epóxi \\
\hline 4 & 0.01326 & epóxi \\
\hline 5 & 0.14583 & carbono/ epóxi \\
\hline 6 & 0.01326 & epóxi \\
\hline 7 & 0.14583 & carbono/ epóxi \\
\hline 8 & 0.01326 & epóxi \\
\hline 9 & 0.14583 & carbono/ epóxi \\
\hline 10 & 0.01326 & epóxi \\
\hline 11 & 0.14583 & carbono/ epóxi \\
\hline 12 & 0.01326 & epóxi \\
\hline 13 & 0.14583 & carbono/ epóxi \\
\hline 14 & 0.01326 & epóxi \\
\hline 15 & 0.14583 & carbono/ epóxi \\
\hline 16 & 0.01326 & epóxi \\
\hline 17 & 0.14583 & carbono/ epóxi \\
\hline 18 & 0.01326 & epóxi \\
\hline 19 & 1.10038 & carbono/ epóxi \\
\hline Total & 3.5 & \\
\hline \multicolumn{2}{|c|}{} \\
\hline \multicolumn{2}{|c|}{} &
\end{tabular}

As propriedades do carbono/ epóxi, do epóxi e do aço carbono (pino de suporte) são aquelas da Tabela 3.

As figuras que serão mostradas adiante com os valores de tensões cisalhantes são numeradas conforma a Tabela 5 anterior. Desta maneira, orientando-se pelo número da camada (LAYR), é possível saber a espessura, localização e material da camada em questão. O comando "LAYR, LN" permite que sejam visualizadas as tensões em uma determinada camada do elemento SHELL99, sendo LN o número da camada (1 a 19).

O pino de suporte, com propriedades do aço carbono, foi representado com elementos finitos sólidos tridimensionais "SOLID45". Entre o corpo-de-prova e o pino de suporte, foram acrescentados elementos finitos de contato "TARGET169" e "CONTA172". O carregamento de ruptura do ensaio de ILSS de $2178 \mathrm{~N}$ foi aplicado em forma de pressão numa área que corresponde à largura do corpo-de- 
prova $x$ largura calculada anteriormente pela teoria de Hertz $(0,24 \mathrm{~mm})$. O modelo representa $1 / 2$ da geometria, aproveitando o plano de simetria yz.

A Figura 48 ilustra o modelo de elementos finitos, a malha de elementos finitos e o carregamento. A Figura 49 também ilustra o modelo, numa vista frontal, mostrando as condições de contorno. A Figura 50 mostra apenas os elementos finitos que formam o corpo-de-prova, com espessura em escala, mostrando as camadas consideradas.

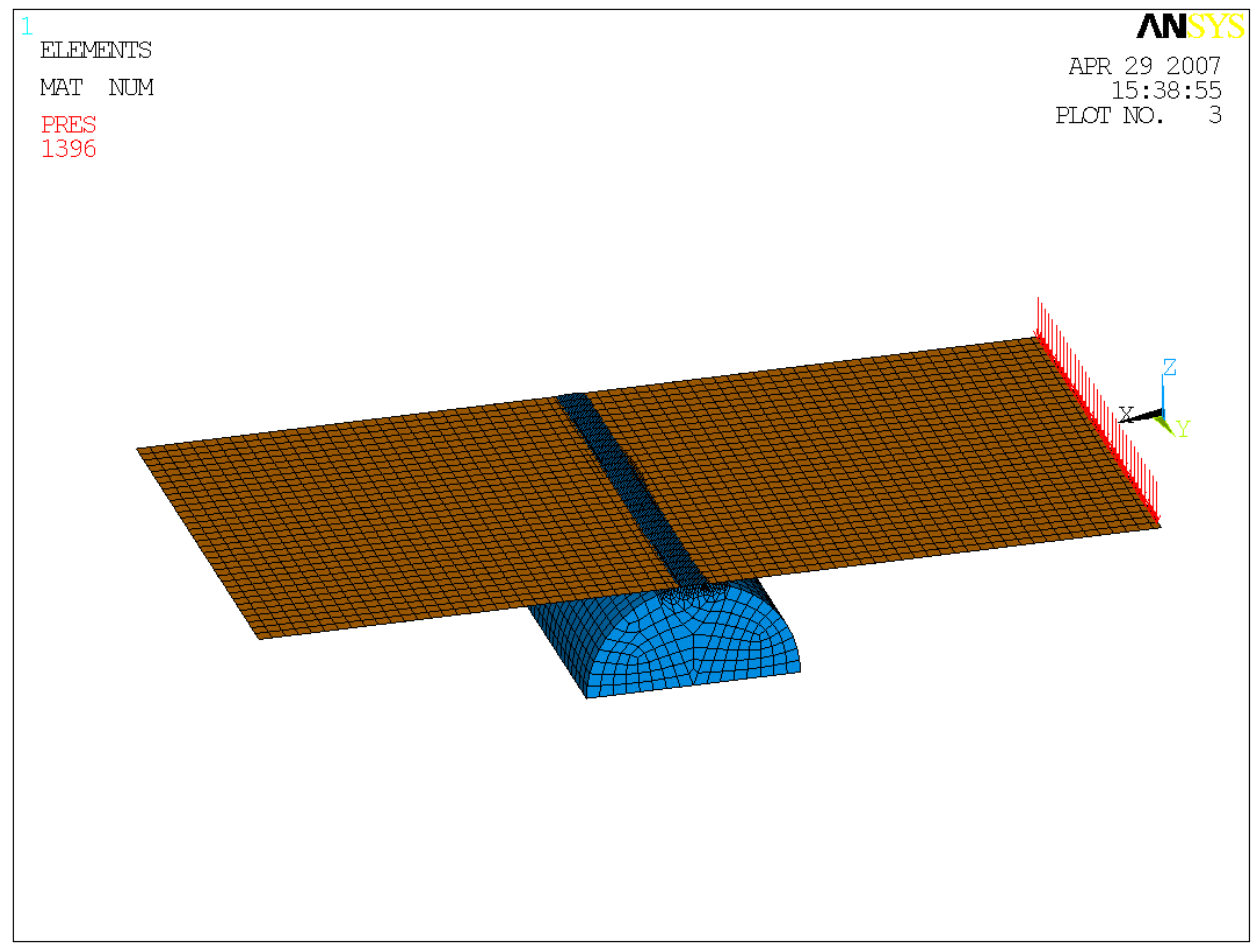

Figura 48: Modelo de casca 


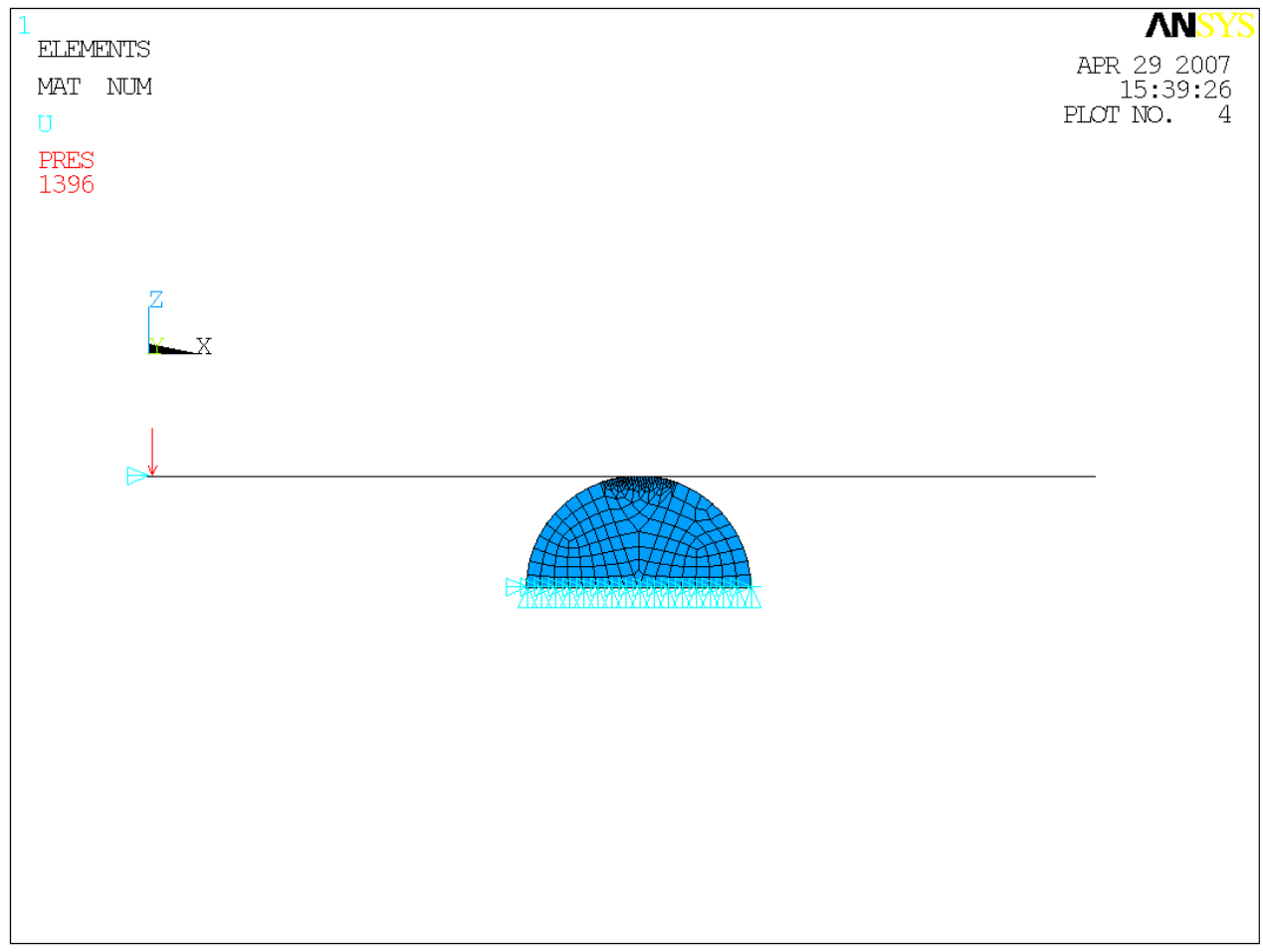

Figura 49: Modelo de elementos finitos (vista frontal)

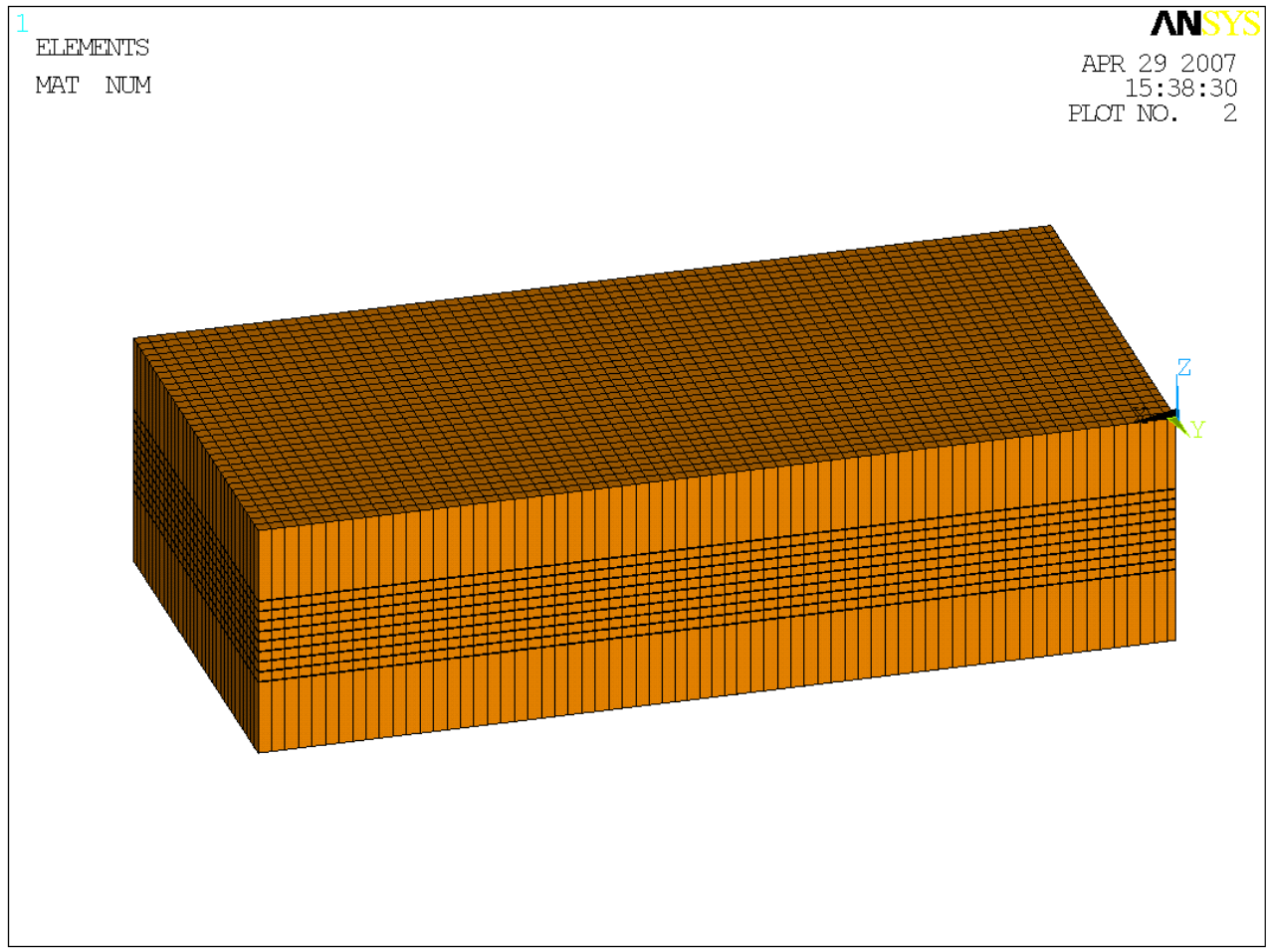

Figura 50: Elementos finitos do corpo-de-prova 


\subsection{Resultados para o Modelo Tridimensional}

A Figura 51 mostra a distribuição das tensões de cisalhamento Sxz em todo o modelo.

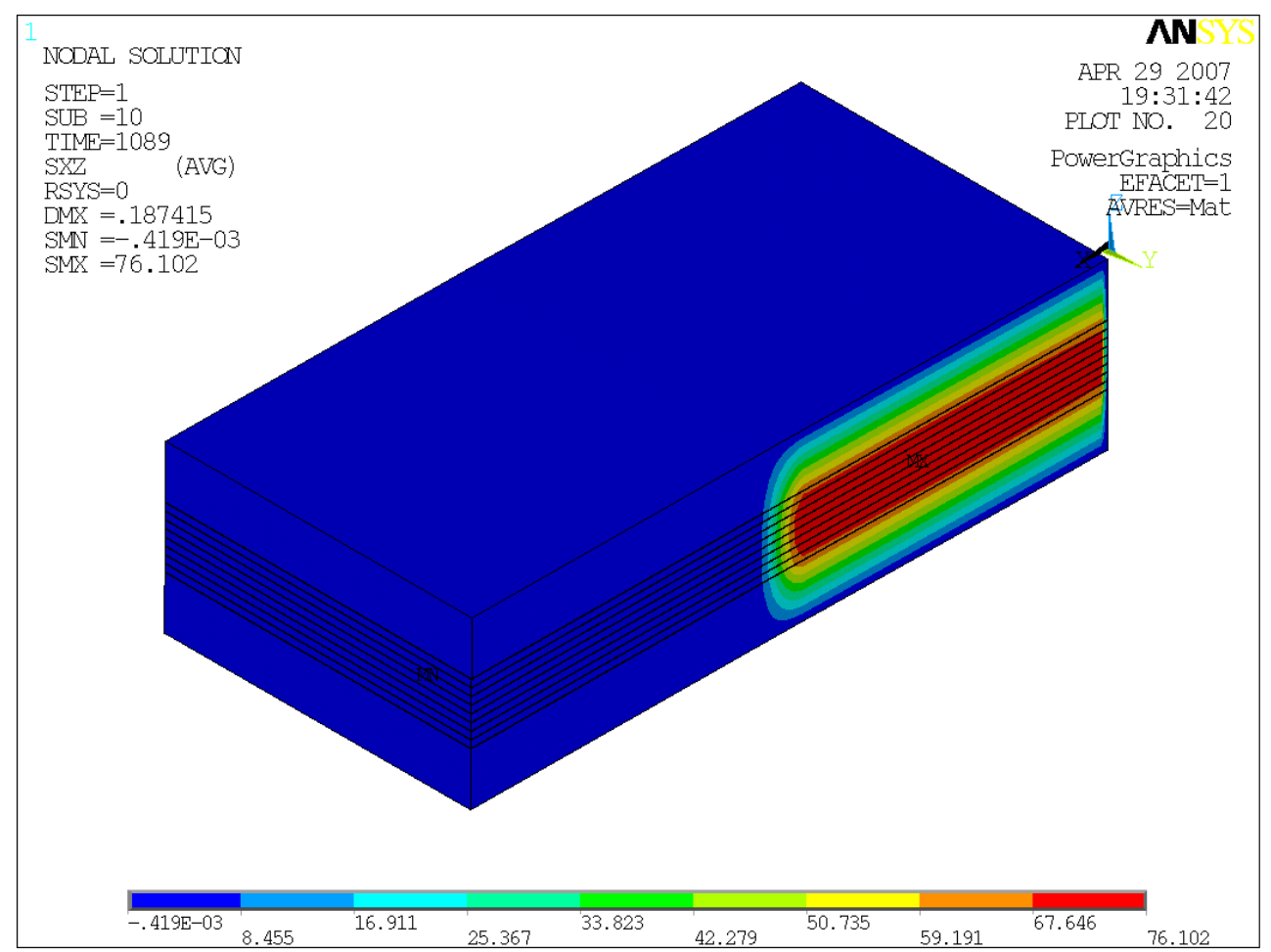

Figura 51: Distribuição das tensões cisalhantes xz em todo corpo-de-prova (MPa)

As tensões nos elementos finitos de casca podem ser calculadas nas superfícies inferior, média e superior. Como cada uma das camadas terá, portanto, tensões nas superfícies inferior, média e superior, foi feito, para uma melhor visualização, foi feito um gráfico com os valores das tensões cisalhantes máximas em cada uma das superfícies de cada uma das camadas do modelo.

As camadas (LAYR) 1 e 19 foram excluídas do gráfico porque possuem, por aproximação, propriedades do carbono/ epóxi, sem considerar as finas camadas interlaminares de matriz polimérica. Desta maneira, o gráfico foi plotado a partir da camada 2 a 18 do modelo de elementos finitos, ou seja, as camadas mais centrais do corpo-de-prova que compreendem as distâncias lineares entre $1,127 \mathrm{~mm}$ e 2,864 $\mathrm{mm}$ ao longo da espessura, orientadas da camada superior 
para a camada inferior. As tensões foram plotadas conforme espessura em relação à superfície inferior do corpo-de-prova. O gráfico da Figura 52 mostra a distribuição de tensão cisalhante.

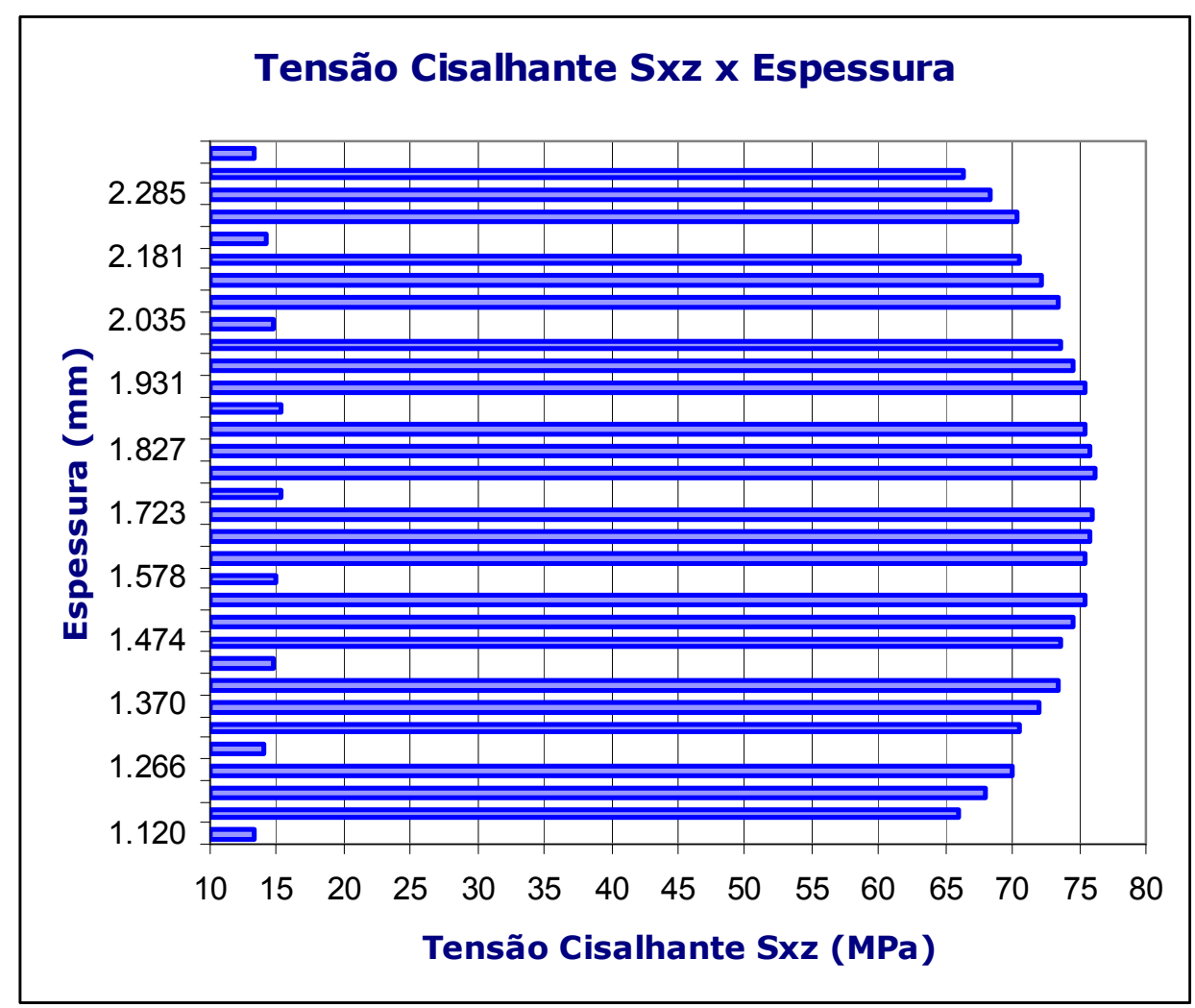

Figura 52: Gráfico tensão cisalhante x espessura

Como o alongamento é o mesmo em todas as camadas, então, o material com maior módulo de elasticidade terá a maior tensão. Nota-se, na Figura 52, que as finas camadas de matriz polimérica (regiões interlaminares) apresentam tensões entre 12 e $16 \mathrm{MPa}$, enquanto as regiões com fibra de carbono apresentam tensões bem maiores, entre 66 e $76 \mathrm{MPa}$.

Um dos motivos pela qual foi feita essa análise foi verificar se há variação da tensão cisalhante através da espessura. Considerando-se as plotagens das tensões cisalhantes nas 19 camadas do modelo, todas apresentaram tensão constante através da largura. Portanto, o fenômeno verificado Kedward (1972) não foi verificado nessa análise. A Figura 53 abaixo mostra as tensões 
cisalhantes Sxz em uma das camadas para melhor ilustrar que não há variação das tensões através da largura.

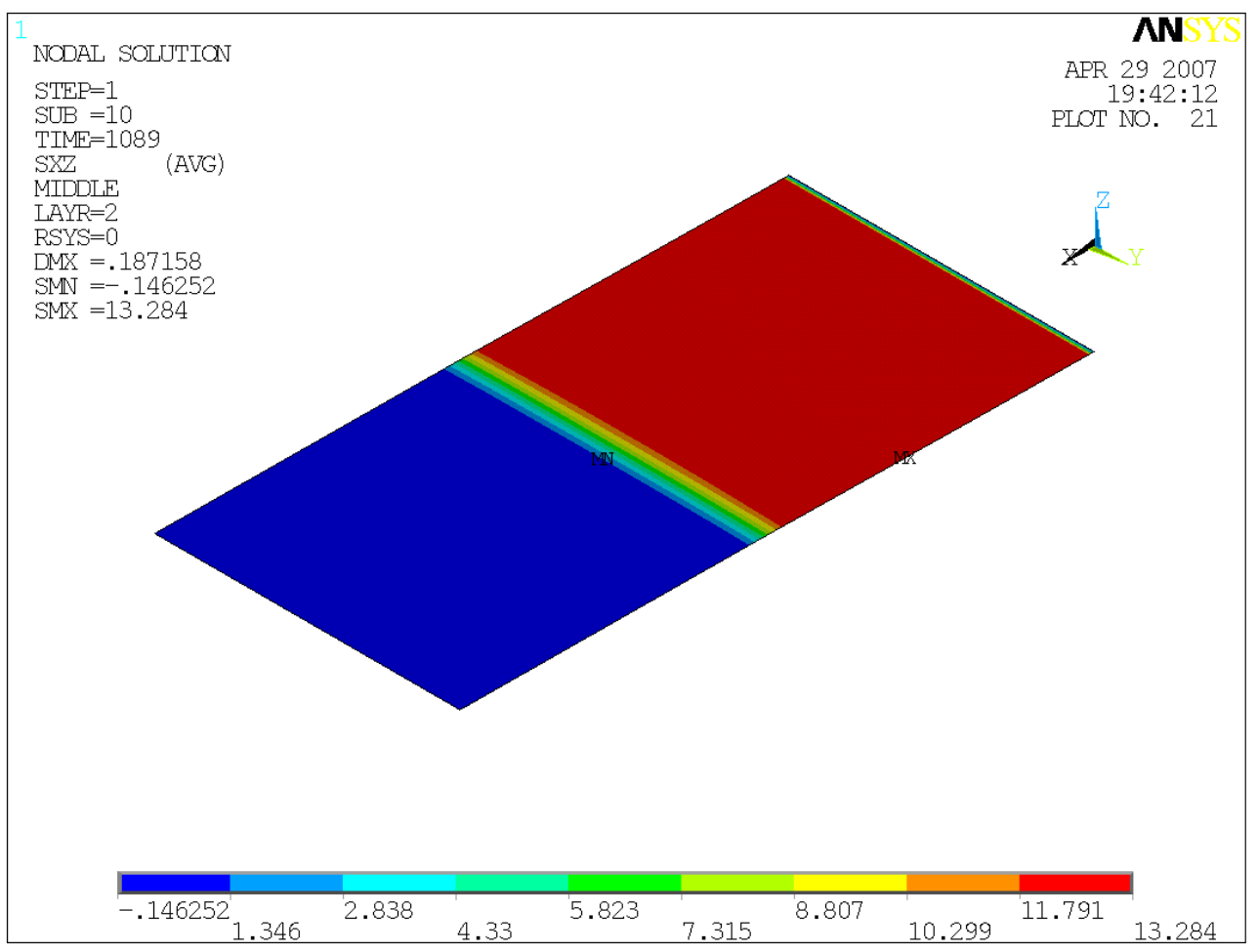

Figura 53: Tensões cisalhantes na camada 2. Não há variação das tensões através da largura. 


\section{DISCUSSÃO DOS RESULTADOS E CONCLUSÕES}

O estudo mostrou uma boa compatibilidade entre os dois métodos de avaliação da tensão de cisalhamento na região interlaminar de um compósito polimérico multicamadas de fibra. Os resultados numéricos $\mathrm{x}$ experimental são comparados na Tabela 6.

Tabela 6: Resultados

\begin{tabular}{|c|c|c|c|c|}
\cline { 2 - 5 } \multicolumn{1}{c|}{} & $\begin{array}{c}\text { Carga } \\
\text { Aplicada } \\
{[\mathrm{N}]}\end{array}$ & $\begin{array}{c}\text { Método } \\
\text { Experimental }\end{array}$ & $\begin{array}{c}\text { Método } \\
\text { Numérico } \\
\text { (modelo plano) }\end{array}$ & $\begin{array}{c}\text { Método } \\
\text { Numérico } \\
\text { (modelo 3-D) }\end{array}$ \\
\hline $\begin{array}{c}\text { Tensão Cisalhante } \\
{[\mathrm{MPa}]}\end{array}$ & 2178 & 72 & 66.2 & 76.0 \\
\hline \multicolumn{3}{c}{ Erro } & $8.1 \%$ & $5.6 \%$ \\
\hline
\end{tabular}

O erro de 5,6\% entre o resultado experimental e o resultado pelo método numérico com modelagem tridimensional é menor que o próprio desvio padrão do resultado durante o ensaio, ou seja, a análise numérica pelo modelo de casca tridimensional é de aproximação bastante satisfatória ao experimental.

A resistência ao cisalhamento entre camadas de um material compósito é de extrema importância pois pode determinar a sua resistência à falha, mesmo que o compósito seja feito à base de fibras de ótimas propriedades mecânicas, como a fibra de carbono, objeto de estudo. Dentre os mecanismos de falha em um material compósito, delaminação (rompimento na interface entre camadas devido ao cisalhamento da camada interlaminar) é bastante comum, portanto, o presente estudo é de grande proveito.

É possível prevenir uma eventual falha em equipamentos de maiores dimensões através de uma análise por elementos finitos, sabendo-se que uma tensão de cisalhamento interlaminar em torno de $70 \mathrm{MPa}$ causa falha no corpode-prova (para um compósito com as características do compósito em estudo), 
O objetivo da dissertação de validar o método numérico dos elementos finitos para estimar a resistência ao cisalhamento da interface entre camadas de um compósito polimérico de fibra de carbono a partir do teste ILSS foi alcançado.

Como proposta para futuros estudos, seria interessante realizar outros ensaios de ILSS, desta vez com diferentes laminados (diferentes orientações de fibra, ou diferentes números de camadas, por exemplo) para verificar se o modelo numérico de elemento finito de casca tridimensional para representar o ensaio continua apresentando resultados próximos àqueles experimentais. Desta maneira, é possível fazer uma validação da proximidade entre o método numérico e o método experimental com um maior espaço amostral. 


\section{REFERÊNCIAS BIBLIOGRÁFICAS}

- Abali, F., Pora, A. and Shivakumar, K.,Modified Short Beam Shear Test for Measurement of Interlaminar Shear Strength of Composites, Journal of Composite Materials, Vol.37, No.5: 453- 464, 2003.

- Almeida, S.F. Mecânica dos Materiais Compósitos (disciplina de nível de pósgraduação - CTA), notas de aula, 2005.

- Alves, A. "Elementos Finitos", 2ª ed. Editora Erica, 2002.

- Anderson, T.L. "Fracture Mechanics: Fundamentals and Applications", CRC Press, 1995.

- Ansys Tutorial, 2006.

- ASTM standard D2344/ D2344M. Apparent interlaminar shear strength of unidirectional parallel fiber composites by short beam method, 2000 .

- Becker, H. Problems of Cryogenic Interlaminar Shear Strength Testing, Advances in Cryogenic Engineering (Materials), 36: 827, 1989.

- Chawla, K.K. "Composite Materials: Science and Engineering”, Springer-Verlag New York Inc., 1987.

- Cui, W.C., Wisnom, M.R. and Jones, N. Failure Mechanisms in Three and Four Point Short Beam Bending Tests of Unidirectional Glass/Epoxy, Journal of Strain Analysis, 27 (4): 235 -243, 1992.

- Daniel, I.M. and Ishai, O. "Engineering Mechanics of Composite Materials", Oxford University Press, 1994. 
- Elawadly, K.M. On the Interlaminar Shear Stress Response for E-Glass/Epoxy Composite, Journal of Composite Materials, Vol.37, No.23/2003: 2149- 2158, 2003.

- Feraboli, P and Kedward, K. T. Four-point bend interlaminar shear testing of uni and multi-directional carbon/epoxy composite systems, Composites: Part A 34 (2003) 1265-1271. 2003.

- Herakovich, C.T. "Mechanics of Fibrous Composites", John Wiley \& Sons, Inc., 1998.

- Jen, M., Kau, Y.S. and Hsu, J.M. Initiation and Propagation of Delamination in a Centrally Notched Composite Laminates, J. Comp. Mat., 27(3): 272, 1993.

- Joo, J.W. and Sun, C.T. Failure Criterion for Laminates Governed by Free Edge Interlaminar Shear Stress, J. Comp. Mat., 26(10): 1510, 1992.

- Kedward K. On the short beam test method. Fibre Sci Technol; (5):85-95, 1972.

- Leitão, E.S. Caracterização Mecânica de Compósitos Poliméricos Bobinados em Diversas Orientações do Reforço, Tese de Mestrado, 2007.

- Negretti, T. Softwares de Simulação Aplicados à Engenharia, Escola de Engenharia da Universidade Presbiteriana Mackenzie, 2006.

- Norton, Robert L. "Machine Design - An Integrated Approach", Prentice-Hall Inc, p. 499-500, 1998.

- Pagano, N.J. Exact Solutions for Composite Laminates in Cylindrical Bending, J. Comp. Mat., 3: 396; 1969. 
- Post D. Shear strains in a graphite/PEEK beam by Moire interferometry with carrier fringes. SEM Fall Conference on Experimental Mechanics, Keystone, CO, 1986.

- Rahhal, W.F. and Kotlensky, W.V. Modified Short-Beam Shear Test, Carbon, 30(3): 385-389, 1992.

- Whitney, J.M. The Effect of Transverse Shear Deformation on the Bending of Laminate Plates, J. Comp. Mat., 3: 534, 1969.

- Wilson, D.W. An Overview of Test Methods used for Shear Characterization of Advanced Composite Materials, Advances in Cryogenic Engineering (Materials), 36: 793, 1989. 